Analysis of FY 2005/2006 Hydrologic Testing and Sampling Results for Well ER-12-4, Nevada Test Site, Nye County, Nevada

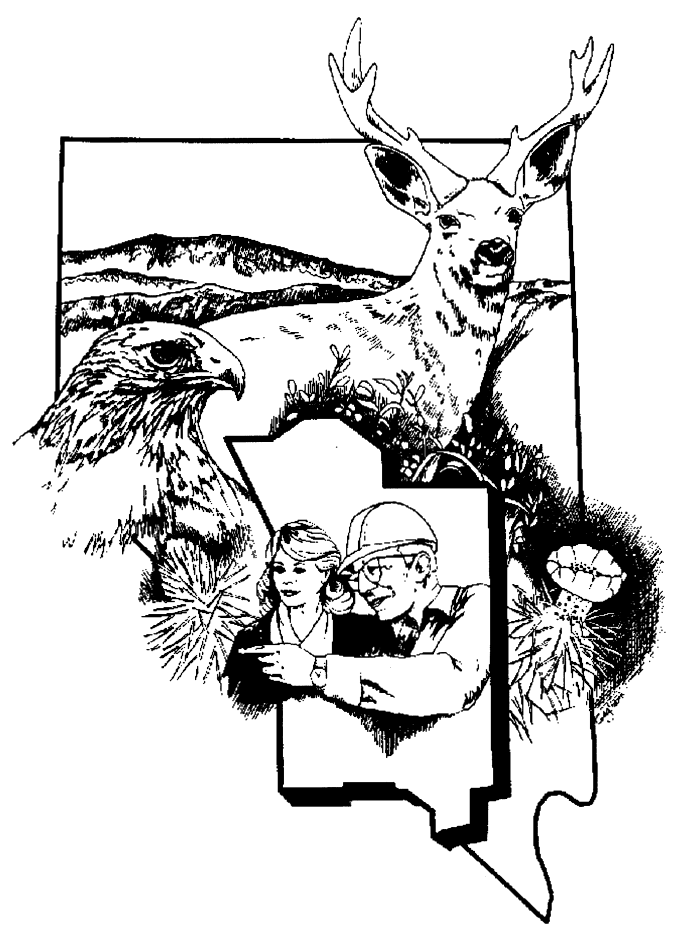

Revision No.: 0

September 2006

Prepared for U.S. Department of Energy under Contract No. DE-AC52-03NA99205

Approved for public release; further distribution is authorized. 
Available for sale to the public from:

U.S. Department of Commerce

National Technical Information Service

5285 Port Royal Road

Springfield, VA 22161

Phone: 800.553.6847

Fax: 703.605.6900

Email: orders@ntis.gov

Online ordering: http://www.ntis.gov/ordering.htm

Available electronically at http://www.osti.gov/bridge

Available for a processing fee to U.S. Department of Energy and its contractors, in paper, from:

U.S. Department of Energy

Office of Scientific and Technical Information

P.O. Box 62

Oak Ridge, TN 37831-0062

Phone: 865.576.8401

Fax: 865.576.5728

Email: reports@adonis.osti.gov

Reference herein to any specific commercial product, process, or service by trade name, trademark, manufacturer, or otherwise, does not necessarily constitute or imply its endorsement, recommendation, or favoring by the United States Government or any agency thereof or its contractors or subcontractors. 


\section{ANALYSIS OF FY 2005/2006 HYDROLOGIC TESTING AND SAMPLING RESULTS FOR WELL ER-12-4, NEVADA TEST SITE, NYE COUNTY, NEVADA}

Revision No.: 0

September 2006

William Fryer, Paul Domski, Irene Farnham

Stoller-Navarro Joint Venture

$7710 \mathrm{~W}$. Cheyenne, Building 3

Las Vegas, NV 89129

Approved for public release; further distribution is authorized. 


\section{ANALYSIS OF FY 2005/2006 HYDROLOGIC TESTING AND SAMPLING RESULTS FOR WELL ER-12-4, NEVADA TEST SITE, NYE COUNTY, NEVADA}

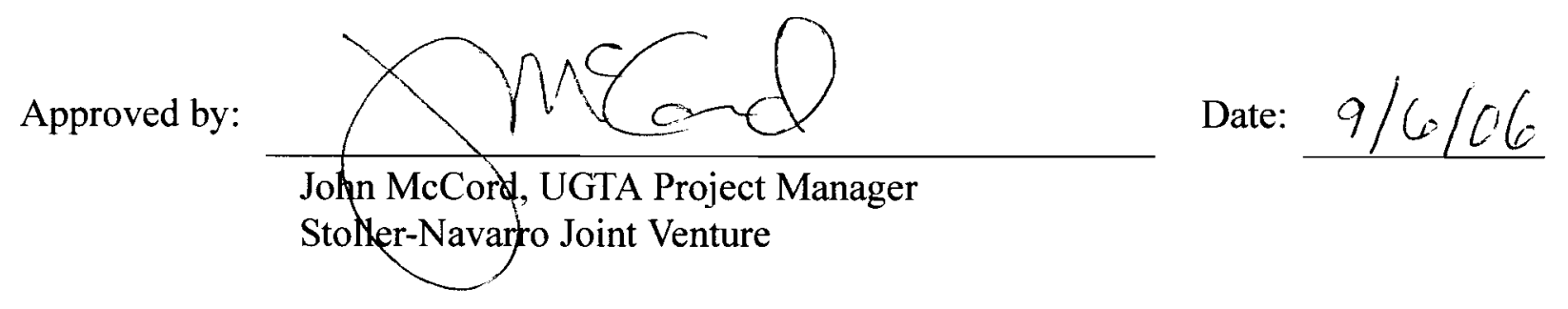




\section{TABLE OF CONTENTS}

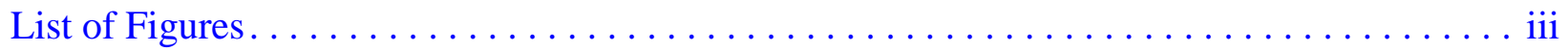

List of Tables. . . . . . . . . . . . . . . . . . . . . . . . . .

List of Acronyms and Abbreviations $\ldots \ldots \ldots \ldots \ldots \ldots \ldots \ldots \ldots \ldots \ldots \ldots \ldots \ldots \ldots \ldots$

$1.0 \quad$ Introduction. . . . . . . . . . . . . . . . . . . . . . . . . . . .

$1.1 \quad$ ER-12-4 Specifications . . . . . . . . . . . . . . . . . . . . . . 1-4

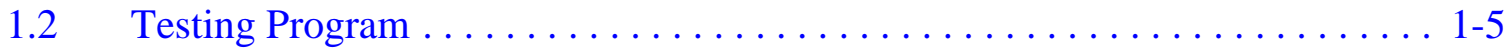

1.3 Analysis Objectives and Goals . . . . . . . . . . . . . . . . . . 1-8

1.4 Report Organization . . . . . . . . . . . . .

2.0 Equilibrium Well Hydraulics . . . . . . . . . . . . . . . . . . . 2-1

2.1 Representative Formation Head . . . . . . . . . . . . . . . . . . 2-1

2.1.1 Water-Level Monitoring. ..................... 2-1

2.1.2 Continuous Water-Level Monitoring . . . . . . . . . . . . . . 2-4

2.1.3 Vertically Discrete Water-Level Measurements . . . . . . . . . . . . 2-4

2.2 Flow in the Well Under Natural Gradient . . . . . . . . . . . . . . . . . 2-5

2.2.1 Non-Pumping Temperature Profiles. . . . . . . . . . . . . . . . . 2-6

2.2.2 Non-Pumping Flow Logs. . . . . . . . . . . . . . . . . . 2-9

$2.2 .3 \quad$ Flow Interpretation. . . . . . . . . . . . . . . . . 2-9

2.3 Barometric Efficiency. ............................. 2-9

2.3.1 Barometric Efficiency Analysis . . . . . . . . . . . . . . . 2-10

2.3.2 Static Formation Head Versus Static Water Level. . . . . . . . . . . . 2-11

3.0 Pumping Well Hydraulics. . . . . . . . . . . . . . . . . . . 3-1

3.1 Pumping-Response Records . . . . . . . . . . . . . . . . . . . 3-1

3.2 Processing of the Water-Level Monitoring Record . . . . . . . . . . . . . 3-2

3.2.1 Background Water-Level Monitoring Record . . . . . . . . . . . . . 3-2

3.2.2 Barometric Pressure Changes and Earth Tides . . . . . . . . . . . . 3-2

3.2.3 Background Water-Level Trends.................... . . 3-3

3.2 .4 Well Losses . . . . . . . . . . . . . . . . . . . . . 3-3

3.2.5 Effects of Temperature Profile Changes $\ldots \ldots \ldots \ldots \ldots \ldots \ldots$. . . . . . . . . . . . . . . . . .

3.3 Pumping-Test Analysis. . . . . . . . . . . . . . . . . . . 3-5

3.3.1 Method of Analysis . . . . . . . . . . . . . . . . . . .

3.3.2 Conceptual Model and Initial Parameter Estimates . . . . . . . . . . . . 3-8

3.3.3 nSights Inverse Model . . . . . . . . . . . . . . . . . 3-10

3.3.4 Best-Fit Parameter Estimates and Uncertainty. . . . . . . . . . . . . 3-11

3.4 Interpretation and Analysis of Measured Discrete Production . . . . . . . . . . 3-14

3.4.1 Temperature Profiles During Pumping . . . . . . . . . . . . . 3-15

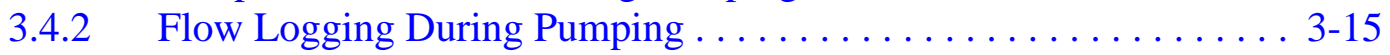

3.4.3 Hydraulic Conductivity Estimates . . . . . . . . . . . . . . . 3-15

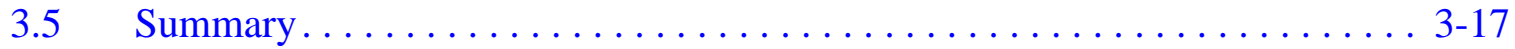

4.0 Groundwater Chemistry $\ldots \ldots \ldots \ldots \ldots \ldots \ldots \ldots \ldots \ldots \ldots \ldots \ldots \ldots \ldots \ldots$

4.1 ER-12-4 Groundwater Characterization Sample Results . . . . . . . . . . . . 4-1 


\section{TABLE OF Contents (Continued)}

4.1.1 Major, Minor, and Trace Constituents and Physical Parameters . . . . 4-2

4.1.2 Environmental Isotopes . . . . . . . . . . . . . . . . . . 4-9

4.1.3 Radionuclide Contaminants . . . . . . . . . . . . . . . . . . . 4 4-10

4.1.4 Colloids. ......................... 4-11

4.1.5 Groundwater Oxidation/Reduction Potential . . . . . . . . . . . . 4-11

4.2 Comparison of ER-12-4 Groundwater Chemistry to Surrounding Wells. . . . 4-16

4.3 Restoration of Natural Groundwater Quality . . . . . . . . . . . . . . . . 4-21 . . . . . . . . . .

4.4 Source Formation(s) of Groundwater Samples . . . . . . . . . . . . . . . 4-23

4.5 Representativeness of Water Chemistry Results . . . . . . . . . . . . . 4-23

4.6 Use of ER-12-4 for Future Monitoring. . . . . . . . . . . . . . . 4-23

5.0 Review of the Testing Program and Analysis $\ldots \ldots \ldots \ldots \ldots \ldots \ldots \ldots \ldots$. 1

5.1 Comments on Well Design. . . . . . . . . . . . . . . . . .

5.2 Comments on the Well Testing Program .................. $5-3$

5.2.1 Pre-Test and Post-Test Monitoring Records . . . . . . . . . . . . 5-3

5.2.2 Background Well Monitoring Record . . . . . . . . . . . . . 5-4

5.2.3 Starting Testing from Non-Equilibrium Condition . . . . . . . . . . . 5-4

5.2.4 Recovery Monitoring after the FY 2005 Testing . . . . . . . . . . . . . 5-4

5.2.5 Lack of Check Valve during FY 2006 Pumping . . . . . . . . . . 5-4

5.3 Comments on Water Quality Analyses..................... 5 . 5

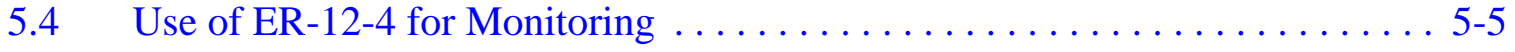

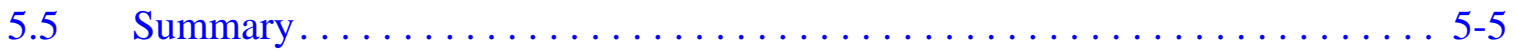

$6.0 \quad$ References................................. 6-1

Appendix A - EMI Logs Containing Deviation Information for Well ER-12-4

A.1.0 Wellbore Deviation Surveys $\ldots \ldots \ldots \ldots \ldots \ldots \ldots \ldots \ldots \ldots \ldots \ldots \ldots \ldots \ldots \ldots$ A-1

Appendix B - Data for Well ER-12-4 FY 2006 Sampling Program

B.1.0 Datalogger Data.............................. B-1

B.2.0 Continuous Multiprobe Logging Data . . . . . . . . . . . . . . . . . B-1 


\section{LIST OF FIGURES}

NUMBER

TITLE

PAGE

1-1 Location of ER-12-4. . . . . . . . . . . . . . . . . . . . . . . . 1-2

1-2 ER-12-4 Tunnels and Selected Nearby Wells and Drillholes $\ldots \ldots \ldots \ldots \ldots \ldots$ 1-3

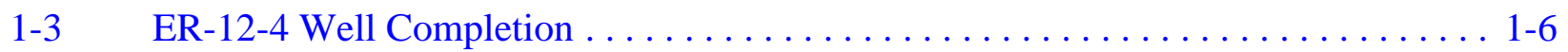

2-1 ER-12-4 Main Completion Water Levels. . . . . . . . . . . . . . . . . . . . 2-3

2-2 ER-12-4 Piezometer Water Levels. . . . . . . . . . . . . . . . . . . . . . . . . . . . . 2-4

2-3 Ambient Temperature and Flow Profiles for ER-12-4. . . . . . . . . . . . 2-7

2-4 Barometric Efficiency for ER-12-4 Main Completion. . . . . . . . . . . . . . . 2-11

3-1 Composite Plot of Pressure and Flow Rate for the FY 2005 Test . . . . . . . . . 3-18

3-2 Composite Plot of Pressure and Flow Rate for the FY 2006 Test . . . . . . . . . . 3-18

3-3 Diagnostic Plot of the FY 2006 Recovery Showing Stabilized Derivative . . . . . . 3-19

3-4 Cartesian Horsetail Plot for the FY 2006 Test . . . . . . . . . . . . . . . . . . . . . . 3-19

3-5 Plot of SSE Versus Transmissivity for the FY 2006 Test . . . . . . . . . . . . . 3-20

3-6 Static Pressure Versus Transmissivity Color Mapped to SSE

for the FY 2006 Test. . . . . . . . . . . . . . . . . . . . . . . . . . . . . 3-20

3-7 Storativity Versus Transmissivity Color Mapped to SSE for the FY 2006 Test . . . 3-21

3-8 Skin Factor Versus Storativity Color Mapped to SSE for the FY 2006 Test. . . . . . 3-21

3-9 Cartesian Horsetail Plot for the FY 2005 Test . . . . . . . . . . . . . . . . . . . . . . . 3-22

3-10 Plot of SSE Versus Transmissivity for the FY 2005 Test . . . . . . . . . . . . . . 3-22

3-11 Static Pressure Versus Transmissivity Color Mapped to SSE

for the FY 2005 Test. . . . . . . . . . . . . . . . . . . . . . . . . . . . . 3-23

3-12 Storativity Versus Transmissivity Color Mapped to SSE for the FY 2005 Test . . . 3-23

3-13 Skin Factor Versus Storativity Color Mapped to SSE for the FY 2005 Test. . . . . . 3-24

3-14 Temperature Profile During Pumping . . . . . . . . . . . . . . . . . . 3-24 


\section{LIST OF FIGURES (CONTINUED)}

NUMBER

4-1 Results of LANL Continuous Multiprobe Analysis for 2006 Sampling Event . . . . 4-14

4-2 Eh-pH Diagrams for $\mathrm{U}, \mathrm{Np}, \mathrm{Pu}$, and $\mathrm{Tc} \ldots \ldots \ldots \ldots \ldots \ldots \ldots \ldots \ldots \ldots$

4-3 Piper Diagram Showing Relative Major Ion Percentages for Groundwater from ER-12-4 and Vicinity. . . . . . . . . . . . . . . . . .

4-4 Stable Isotope Composition for ER-12-4 and Vicinity . . . . . . . . . . . . . 4-22 


\section{LIST OF TABLES}

NUMBER

TITLE

PAGE

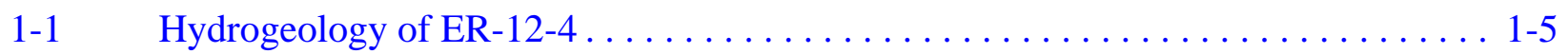

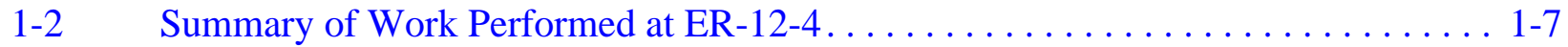

2-1 ER-12-4 Water-Level Measurements . . . . . . . . . . . . . . . . 2-2

3-1 Estimated Transmissivity for the FY 2006 ER-12-4 Hydraulic Test . . . . . . . . 3-10

3-2 Estimated Parameters for the ER-12-4 Hydraulic Test . . . . . . . . . . . . . . . 3-12

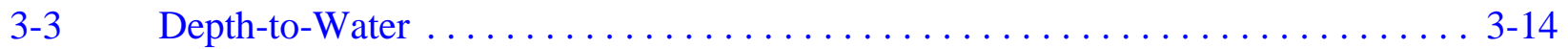

3-4 Hydraulic Conductivity Estimates. . . . . . . . . . . . . . . . . 3-16

4-1 Analytical Results for Groundwater Characterization Samples at ER-12-4 . . . . . . 4-3

4-2 Additional Analyses Results for ER-12-4 Wellhead Composite Samples . . . . . . 4-6

4-3 Colloid Analyses for ER-12-4 Composite Wellhead Samples . . . . . . . . . . . . 4-12

4-4 Groundwater Chemistry Data for ER-12-4 and Surrounding Area . . . . . . . . . 4-17

A.1-1 EMI Log with Borehole Deviation Information $\ldots \ldots \ldots \ldots \ldots \ldots \ldots \ldots \ldots$ A-1 


\section{LIST OF ACRONYMS AND ABBREVIATIONS}

\begin{tabular}{|c|c|}
\hline Ag & Silver \\
\hline $\mathrm{AgCl}$ & Silver chloride \\
\hline amsl & Above mean sea level \\
\hline ATCU & Argillic Tuff Confining Unit \\
\hline atoms/g & Atoms per gram \\
\hline $\mathrm{BE}$ & Barometric efficiency \\
\hline bgs & Below ground surface \\
\hline $\mathrm{BN}$ & Bechtel Nevada \\
\hline $\mathrm{Br}^{-}$ & Bromide \\
\hline BRA & Belted Range Aquifer \\
\hline BRCU & Belted Range Confining Unit \\
\hline${ }^{14} \mathrm{C}$ & Carbon-14 \\
\hline${ }^{\circ} \mathrm{C}$ & Degrees Celsius \\
\hline CA & Carbonate Aquifer \\
\hline $\mathrm{Ca}$ & Calcium \\
\hline $\mathrm{CaCO}_{3}$ & Calcium carbonate \\
\hline CAU & Corrective Action Unit \\
\hline $\mathrm{Cl}$ & Chlorine \\
\hline $\mathrm{cm}$ & Centimeter \\
\hline $\mathrm{CO}_{3}$ & Carbonate \\
\hline CS & Carbon steel \\
\hline DO & Dissolved oxygen \\
\hline DOE & U.S. Department of Energy \\
\hline DRI & Desert Research Institute \\
\hline EMAX & EMAX Laboratories, Inc. \\
\hline EMI & Electric Micro-Imager \\
\hline $\mathrm{Fe}$ & Iron \\
\hline $\mathrm{Fe}^{2+}$ & Iron in the +2 oxidation state \\
\hline $\mathrm{Fe}_{\mathrm{T}}$ & Total iron \\
\hline
\end{tabular}




\section{LIST OF ACRONYMS AND ABBREVIATIONS (CONTINUED)}

$\mathrm{ft}$

$\mathrm{ft} / \mathrm{d}$

$\mathrm{ft}^{2} / \mathrm{d}$

FY

gal

gpm

GTFM

$\mathrm{HCO}_{3}$

$\mathrm{He}$

HGU

HSU

in.

K

LANL

LCA

LCA3

LCCU1

$\mathrm{LiBr}$

LLNL

LTCU

LVTA

m

M

$\mathrm{Mg}$

MGCU

$\mathrm{mg} / \mathrm{L}$

$\mathrm{Mn}$

$\mathrm{Mn}_{\mathrm{T}}$

$\mathrm{mV}$

Foot

Feet per day

Square feet per day

Fiscal year

Gallon

Gallons per minute

Graph Theoretic Field Model

Bicarbonate

Helium

Hydrogeologic unit

Hydrostratigraphic unit

Inch

Hydraulic conductivity

Los Alamos National Laboratory

Lower Carbonate Aquifer

Lower Carbonate Aquifer - thrust plate

Lower Clastic Confining Unit - thrust plate

Lithium bromide

Lawrence Livermore National Laboratory

Lower Tuff Confining Unit

Lower Vitric Tuff Aquifer

Meter

Molar

Magnesium

Mesozoic Granite Confining Unit

Milligrams per liter

Manganese

Total manganese

Millivolt 


\section{List of ACRONYMS AND ABbREVIATIONS (Continued)}

\begin{tabular}{|c|c|}
\hline N/A & Not applicable \\
\hline NA & Not available \\
\hline $\mathrm{Na}$ & Sodium \\
\hline ND & Not detected \\
\hline NAD & North American Datum \\
\hline $\mathrm{NH}_{3}$ & Ammonia \\
\hline $\mathrm{nm}$ & Nanometer \\
\hline NM & Not measured \\
\hline $\mathrm{nm}$ & Nanometer \\
\hline NNSA/NSO & $\begin{array}{l}\text { U.S. Department of Energy, National Nuclear Security Administration } \\
\text { Nevada Site Office }\end{array}$ \\
\hline $\mathrm{NO}_{2}^{-}$ & Nitrite \\
\hline $\mathrm{NO}_{3}^{-}$ & Nitrate \\
\hline $\mathrm{Np}$ & Neptunium \\
\hline $\mathrm{NpO}_{2}{ }^{+}$ & Neptunyl ion \\
\hline NTS & Nevada Test Site \\
\hline nSights & n-Dimensional Statistical Inverse Graphical Hydraulic Test Simulator \\
\hline ORP & Oxidation Reduction Potential \\
\hline OSBCU & Oak Springs Butte Confining Unit \\
\hline $\mathrm{P}$ & Pressure \\
\hline PAI & Paragon Analytics, Inc. \\
\hline particles/mL & Particles per milliliter \\
\hline $\mathrm{pCi} / \mathrm{L}$ & Picocuries per liter \\
\hline pmc & Percent modern carbon \\
\hline $\mathrm{ppb}$ & Parts per billion \\
\hline psi & Pounds per square inch \\
\hline $\mathrm{Pt}$ & Platinum \\
\hline $\mathrm{Pu}$ & Plutonium \\
\hline PXD & Pressure transducer \\
\hline
\end{tabular}




\section{LIST OF ACRONYMS AND ABBREVIATIONS (CONTINUED)}

\begin{tabular}{|c|c|}
\hline RVA & Redrock Valley Aquifer \\
\hline$S$ & Storativity \\
\hline SHE & Standard hydrogen electrode \\
\hline SNJV & Stoller-Navarro Joint Venture \\
\hline SNL & Sandia National Laboratories \\
\hline SpCond & Specific conductance \\
\hline $\mathrm{Sr}$ & Strontium \\
\hline SS & Stainless steel \\
\hline SSE & Sum of squared errors \\
\hline SU & Standard unit \\
\hline $\mathrm{T}$ & Transmissivity \\
\hline Tc & Technetium \\
\hline $\mathrm{TcO}_{4}^{-}$ & Pertechnetate ion \\
\hline TCU & Tuff Confining Unit \\
\hline TD & Total depth \\
\hline TFM & Thermal Flow meter \\
\hline $\mathrm{TM}$ & Timber Mountain \\
\hline $\mathrm{U}$ & Uranium \\
\hline UCCU & Upper Clastic Confining Unit \\
\hline UGTA & Underground Test Area \\
\hline $\mathrm{UO}_{2}^{2+}$ & Uranyl ion \\
\hline USGS & U.S. Geological Survey \\
\hline UTM & Universal Transverse Mercator \\
\hline VTA & Vitric Tuff Aquifer \\
\hline WTA & Welded Tuff Aquifer \\
\hline$\delta^{13} \mathrm{C}$ & Delta carbon-13 \\
\hline$\delta \mathrm{D}$ & Delta deuterium \\
\hline$\delta^{18} \mathrm{O}$ & Delta oxygen-18 \\
\hline$\mu g / L$ & Micrograms per liter \\
\hline
\end{tabular}




\section{List of ACRONYMS AND ABbREVIATIONS (Continued)}

$\mu \mathrm{S} / \mathrm{cm} \quad$ MicroSiemens per centimeter

\% $\quad$ Per mil 


\subsection{INTRODUCTION}

This report documents the analysis of data collected for ER-12-4 during the fiscal year (FY) 2005 Rainier Mesa/Shoshone Mountain well development and hydraulic testing program (herein referred to as the "testing program") and hydraulic response data from the FY 2006 Sampling Program. Well ER-12-4 was constructed and tested as a part of the Corrective Action Unit (CAU) 99, Rainier Mesa/Shoshone Mountain, Phase I drilling program during FY 2005. These activities were conducted on behalf of the U.S. Department of Energy (DOE), National Nuclear Security Administration Nevada Site Office (NNSA/NSO) for the Underground Test Area (UGTA) Subproject.

As shown on Figure 1-1, ER-12-4 is located in central Rainier Mesa, in Area 12 of the Nevada Test Site (NTS). Figure 1-2 shows the well location in relation to the tunnels under Rainier Mesa. The well was drilled to a total depth (TD) of 3,715 feet (ft) below ground surface (bgs) (surface elevation 6,883.7 $\mathrm{ft}$ above mean sea level [amsl]) in the area of several tunnels mined into Rainier Mesa that were used historically for nuclear testing (NNSA/NSO, 2006). The closest nuclear test to the well location was MIGHTY OAK (U-12t.08), conducted in the U-12t Tunnel approximately $475 \mathrm{ft}$ north of the well site. The MIGHTY OAK test working point elevation was located at approximately 5,620 ft amsl. The MIGHTY OAK test had an announced yield of “less than 20 kilotons” (DOE/NV, 2000).

The purpose of this hydrogeologic investigation well is to evaluate the deep Tertiary volcanic section below the tunnel level, which is above the regional water table, and to provide information on the section of the lower carbonate aquifer - thrust plate (LCA3), located below the Tertiary volcanic section (SNJV, 2005b). Details on the drilling and completion program are presented in the Completion Report for Well ER-12-4 Corrective Action Unit 99: Rainier Mesa - Shoshone Mountain (NNSA/NSO, 2006). 


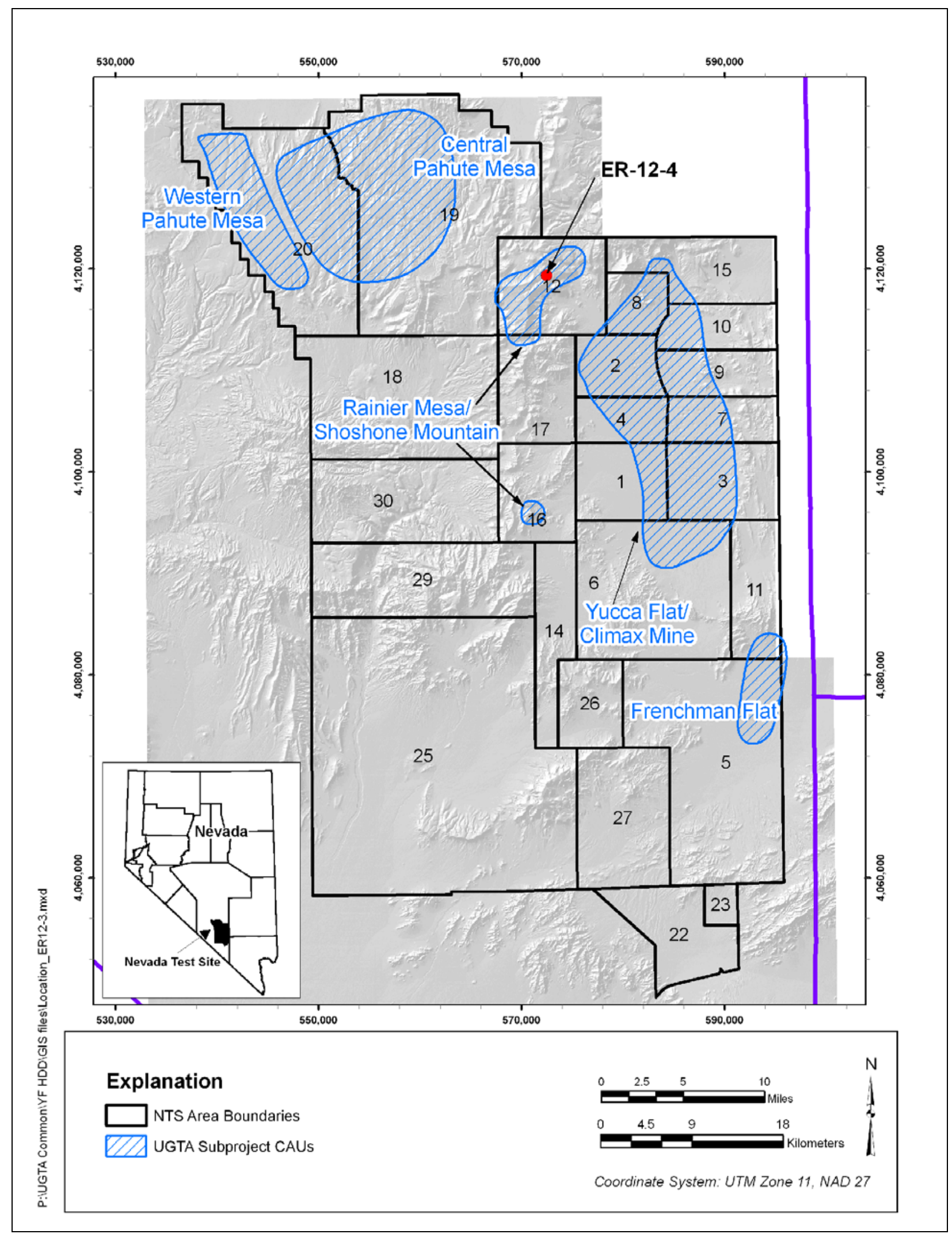

Figure 1-1

Location of ER-12-4 


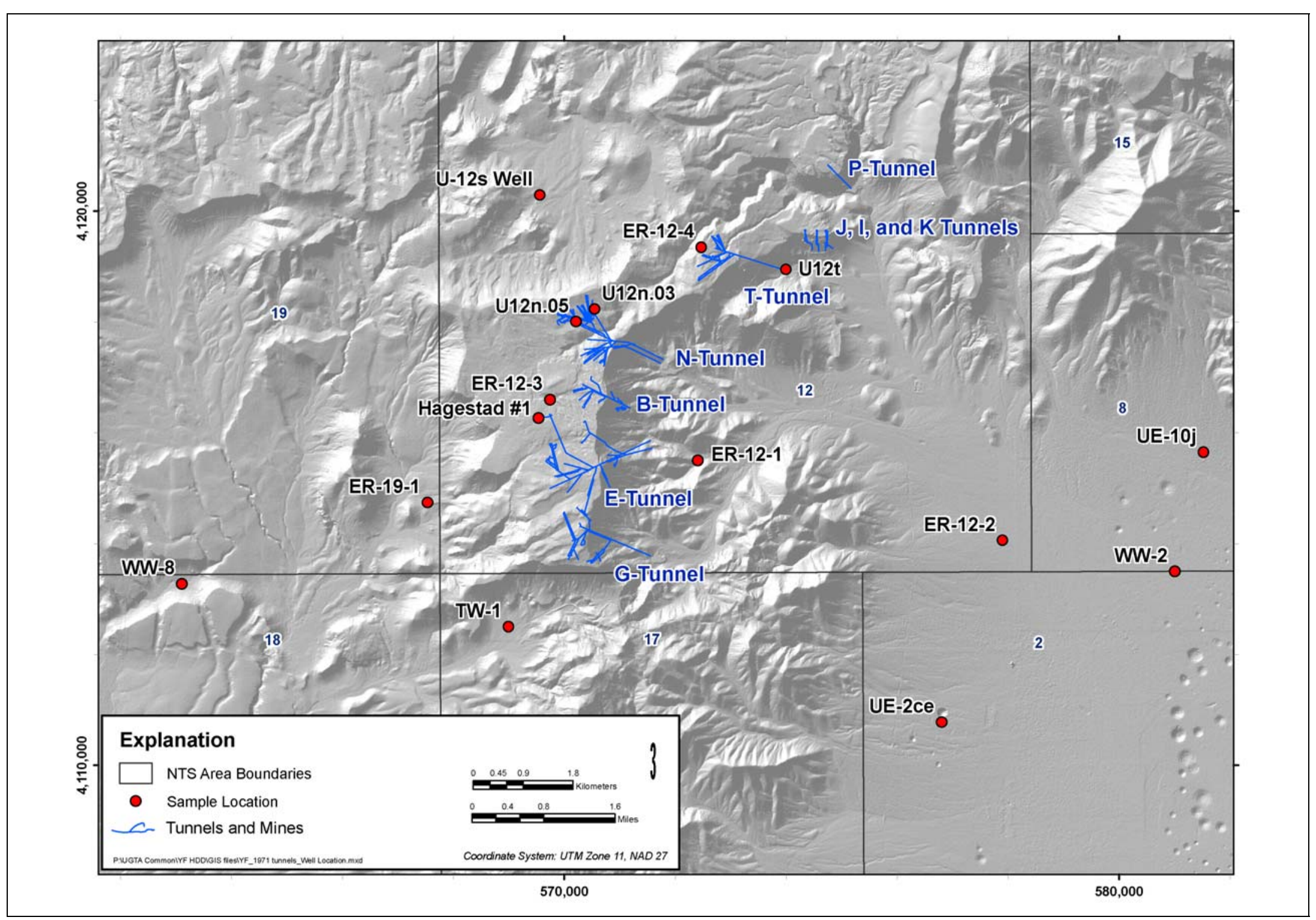

Figure 1-2

ER-12-4 Tunnels and Selected Nearby Wells and Drillholes 
Participants in ER-12-4 testing activities were: Stoller-Navarro Joint Venture (SNJV), Bechtel Nevada (BN), Desert Research Institute (DRI), Los Alamos National Laboratory (LANL), Lawrence Livermore National Laboratory (LLNL), and the U.S. Geological Survey (USGS). Stoller-Navarro Joint Venture served as the lead contractor responsible for providing site supervision, development and testing services, and waste management services; BN provided construction and engineering support services; DRI provided well logging services and participated in groundwater sampling and laboratory analyses; LANL and LLNL participated in groundwater sampling and laboratory analyses; and the USGS performed laboratory analyses. Analyses of data from the ER-12-4 testing program presented in this document were performed by SNJV except as noted. These same contractors participated in the FY 2006 Sampling Program.

\subsection{ER-12-4 Specifications}

Well ER-12-4 was drilled to a TD of 3,715 ft bgs between May 7 and June 1, 2005, using conventional rotary drilling equipment with direct air-foam circulation. Upon reaching an intermediate depth of 2,501 ft bgs, a 13.375-inch (in.) carbon-steel (CS) surface casing was installed to a depth of 2,225.0 ft bgs and cemented in place at the bottom (NNSA/NSO, 2006). A 2.375-in. CS piezometer was installed between the 13.375-in. CS surface casing and the borehole wall, accessing upper volcanic hydrostratigraphic units (HSUs) to a depth of 1,988 ft bgs. The piezometer string was installed to a depth of 1,967.6 ft bgs, slotted from 1,836.2 to $1935.1 \mathrm{ft}$ bgs. Upon reaching a TD of 3,715 ft bgs, the well was completed with 7.625-in. CS production casing (with internal epoxy coating) from the surface to 3,023.7 ft bgs; a stainless-steel (SS) crossover from 3,023.7 to 3,025.6 ft bgs; and 5.5-in. SS production casing from 3,025.6 to 3,713.5 ft bgs, including the bullnose (NNSA/NSO, 2006). There are seven slotted joints of casing alternating with blank joints in the interval from 3,111.4 to 3,668.7 ft bgs to access the annulus, with a sediment sump below. Cement was not used to isolate individual screened intervals, nor was stemming material placed between the production casing and borehole. The main completion interval accesses Paleozoic dolomite and limestone.

The static water level in ER-12-4 (main) during the period of the testing program was in the depth range of 2,566.35 to 2,572.13 ft bgs, below the top of the carbonate HSU, corresponding to an elevation range of 4,317.35 to 4,311.57 ft amsl. During this same period, the static water level in the 
ER-12-4 piezometer was in the depth range of 916.47 to $915.97 \mathrm{ft}$ bgs, corresponding to an elevation range of 5,967.23 to 5,967.73 ft amsl. (See Table 2-1 for all water-level measurements and associated information.)

Detailed geologic information was collected during drilling (including geologic samples, cuttings, and sidewall core) for stratigraphic and lithologic interpretation. Geophysical logs, including image-type logs, were run to assist with characterization of geologic units. The formations and HSUs penetrated in ER-12-4 are shown in Table 1-1. Detailed lithologic and stratigraphic information can be found in NNSA/NSO (2006). Hydrogeologic unit (HGUs) delineations are included on

Figure 1-3.

Table 1-1

Hydrogeology of ER-12-4

\begin{tabular}{|c|c|c|c|c|}
\hline \multicolumn{2}{|l|}{ Hydrostratigraphic Unit } & \multicolumn{2}{|c|}{ Hydrogeologic Unit } & \multirow{2}{*}{$\begin{array}{c}\begin{array}{c}\text { Depth Interval } \\
\text { (ft bgs) }\end{array} \\
0 \text { to } 296\end{array}$} \\
\hline Timber Mountain welded tuff aquifer & TM-WTA & Welded tuff aquifer & WTA & \\
\hline Timber Mountain lower vitric tuff aquifer & TM-LVTA & Vitric tuff aquifer & VTA & 296 to 730 \\
\hline Belted Range aquifer & BRA & Welded tuff aquifer & WTA & 730 to 810 \\
\hline Lower vitric tuff aquifer 1 & LVTA1 & Vitric tuff aquifer & VTA & 810 to 960 \\
\hline Belted Range confining unit & BRCU & \multirow{3}{*}{ Tuff confining unit } & \multirow{3}{*}{ TCU } & 960 to 1,590 \\
\hline Oak Springs Butte confining unit & OSBCU & & & 1,590 to 2,212 \\
\hline Argillic tuff confining unit & ATCU & & & 2,212 to 2,488 \\
\hline Lower carbonate aquifer - thrust plate & LCA3 & Carbonate aquifer & $\mathrm{CA}$ & 2,488 to 3,715 \\
\hline
\end{tabular}

\subsection{Testing Program}

Development and hydraulic testing of Well ER-12-4 was conducted between July 26 and August 22, 2005. The development objectives included removing residual drilling fluids and improving the hydraulic connection with the formation. The hydraulic testing objectives focused on obtaining further hydrogeologic, geochemical, and radiochemical data for the site. Details on the data collected during development and testing are presented in the report Rainier Mesa Well ER-12-4 Data Report for Well Development and Hydraulic Testing (SNJV, 2006b). 


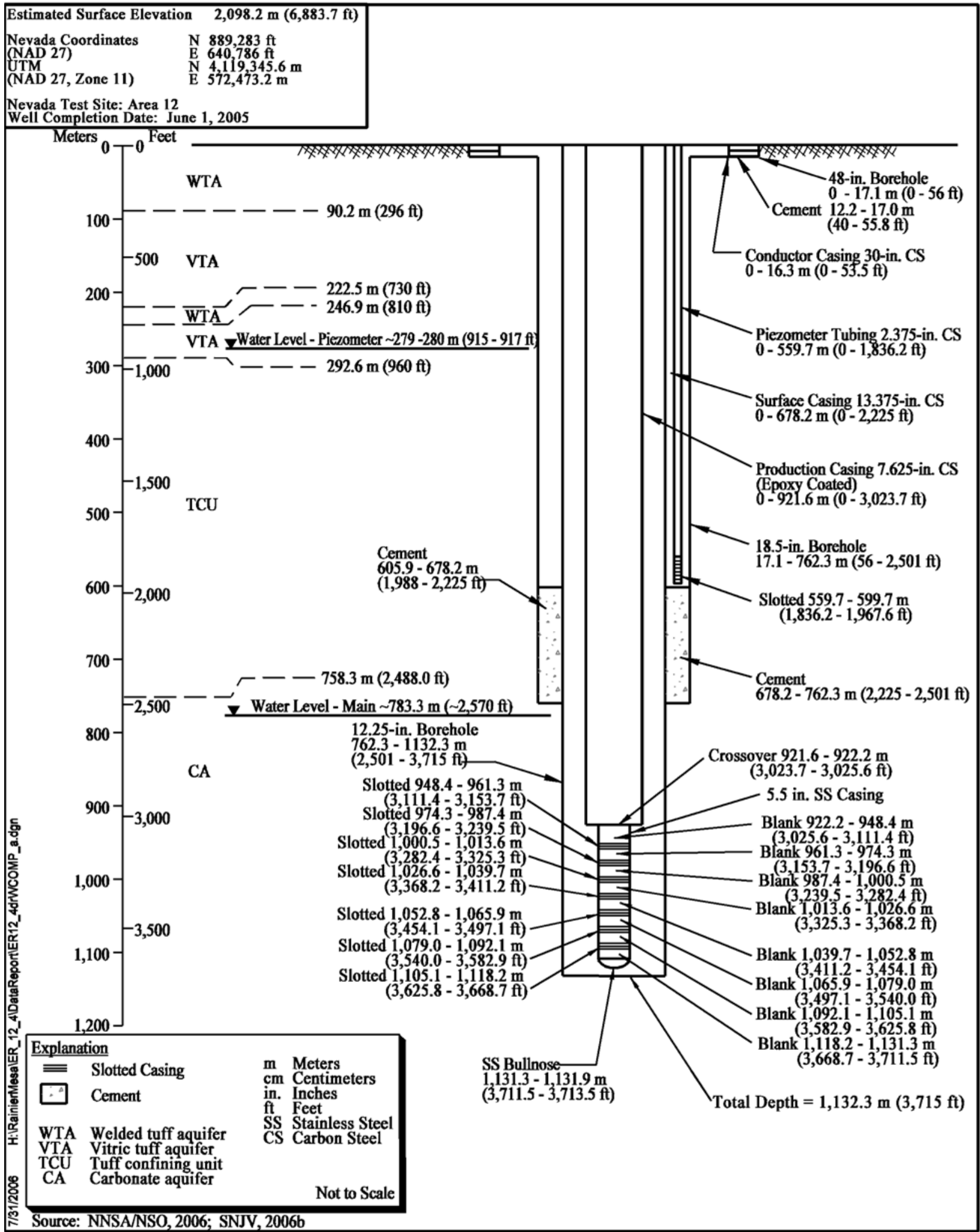

Figure 1-3

ER-12-4 Well Completion 
The hydraulic testing program included:

- Record of the ambient water level

- Well development, including step-drawdown tests

- Flow and temperature logging under non-pumping conditions

- Flow and temperature logging during pumping

- Single-well constant-rate pumping test and recovery monitoring

A summary schedule of the completed activities is provided in Table 1-2.

Table 1-2

Summary of Work Performed at ER-12-4

\begin{tabular}{|c|c|c|c|}
\hline Activity & $\begin{array}{c}\text { Start } \\
\text { Date }\end{array}$ & $\begin{array}{c}\text { Finish } \\
\text { Date }\end{array}$ & $\begin{array}{c}\text { Duration } \\
\text { in Days }\end{array}$ \\
\hline \hline Mobilize development and testing equipment & $6 / 20 / 2005$ & $6 / 22 / 2005$ & 2 \\
\hline Predevelopment water-level measurements & $6 / 22 / 2005$ & $7 / 19 / 2005$ & 28 \\
\hline Install electric submersible pump and access line & $7 / 20 / 2005$ & $7 / 26 / 2005$ & 7 \\
\hline $\begin{array}{r}\text { Check pump functionality, develop well, and conduct } \\
\text { step-drawdown testing }\end{array}$ & $7 / 26 / 5005$ & $7 / 31 / 2005$ & 6 \\
\hline $\begin{array}{r}\text { Conduct temperature and spinner flow logging, and collect } \\
\text { depth-discrete samples }\end{array}$ & $8 / 1 / 2005$ & $8 / 4 / 2005$ & 3 \\
\hline Monitor water-level recovery & $8 / 5 / 2005$ & $8 / 5 / 2005$ & 1 \\
\hline Conduct constant-rate test, and collect groundwater \\
characterization samples from well head & $8 / 5 / 2005$ & $8 / 16 / 2005$ & 11 \\
\hline Monitor water-level recovery & $8 / 16 / 2005$ & $8 / 22 / 2005$ & 6 \\
\hline Demobilize development and testing equipment & $8 / 25 / 2005$ & $8 / 26 / 2005$ & 1 \\
\hline Perform Thermal Flow meter (TFM), and ChemTool logging & $8 / 24 / 2005$ & $8 / 25 / 2005$ & 1 \\
\hline
\end{tabular}

Source: SNJV, 2006b

The FY 2006 Sampling Program took place in April and May 2006 for the purpose of collecting groundwater samples. A record of the drawdown response during and following purging was included in the analysis. The sampling activities are detailed in a memo (SNJV, 2006c), and the drawdown data record is included in Appendix B. 


\subsection{Analysis Objectives and Goals}

The testing program was designed to provide information on local hydrologic conditions and HSU hydraulic parameters for use in the CAU-scale flow and transport models. The objective of the analysis is to maximize the hydrogeologic information drawn from data collected. Specifically, both composite and interval-specific formation hydraulic parameters are estimated.

\subsection{Report Organization}

Section 1.0 contains introductory material.

Section 2.0 discusses the analysis of the non-pumping (pseudo-static) natural-gradient well hydrology.

Section 3.0 discusses the well hydraulics during pumping, presents analyses of the constant-rate test, and presents flow and temperature logging.

Section 4.0 presents analysis of the geochemical information collected.

Section 5.0 contains a review of the test design and implementation, and interpretation and analysis of testing data.

Section 6.0 contains references.

Appendix A includes two Electric Micro-Imager (EMI) logs that contain deviation information.

Appendix B includes the hydraulic-response record and water quality data from the FY 2006 sampling event. 


\subsection{EQUiLIBRIUM WeLl HYDRAULICS}

This section evaluates the hydrology of ER-12-4 in the static, non-pumping condition to quantify hydraulic characteristics of the well under equilibrium conditions. This provides a baseline for evaluating factors that may influence the measured response to production during hydraulic testing. The relevant characteristics include the representative head for the well completion, equilibrium borehole temperature profile, vertical gradient within the completion interval and resultant vertical circulation, and discrete-interval horizontal flow into or out of the formation.

\subsection{Representative Formation Head}

Formation head, hydraulic head expressed as equivalent elevation head, is of interest for several purposes. The head value may be used for mapping the formation head across an area of interest to determine head gradients and infer the direction of groundwater flow. It is also necessary to know whether the well is in equilibrium at the time of testing and to determine when it has recovered to an equilibrium condition. Water-level monitoring information collected periodically on schedules with different time scales allows the evaluation of different components of the natural variation of formation head such as responses to barometric pressure variation, earth tides, background trends, and responses to imposed stress during testing. Water-level information is available for ER-12-4 since the initial well completion, collected both by the Environmental Restoration contractor (SNJV) and by the USGS.

\subsubsection{Water-Level Monitoring}

Table 2-1 shows ER-12-4 water-level measurements; note that accuracy varies for different measurements. Measurements from logs or uncalibrated electric tapes may be recorded to the nearest $0.01 \mathrm{ft}$, but the uncertainty is $+/$ - the listed accuracy. Later water-level measurements were made with calibrated equipment and are considered accurate to $0.1 \mathrm{ft}$. The water-level elevations are calculated assuming an undeviated borehole. A full-depth deviation survey has not been run in this well. Partial 
Table 2-1

ER-12-4 Water-Level Measurements

\begin{tabular}{|c|c|c|c|c|c|c|c|}
\hline Date & Time & $\begin{array}{c}\text { Depth-to-Water } \\
\text { (ft) }\end{array}$ & Method & Accuracy & Source & $\begin{array}{c}\text { Water-Level } \\
\text { Elevation }^{\mathrm{a}} \\
\text { (ft amsl) }^{\text {(ft ams }}\end{array}$ & $\begin{array}{l}\text { Water-Level } \\
\text { Elevation } \\
\text { (m amsl) }\end{array}$ \\
\hline \multicolumn{8}{|c|}{ ER-12-4 Main Completion } \\
\hline $3 / 9 / 2006$ & $12: 15$ & $2,567.54$ & Calibrated Electric Tape & Nearest Tenth Foot & USGS & $4,316.16$ & $1,315.57$ \\
\hline $12 / 6 / 2005$ & $14: 16$ & $2,569.19$ & Calibrated Electric Tape & Nearest Tenth Foot & USGS & $4,314.51$ & $1,315.06$ \\
\hline $9 / 22 / 2005$ & $12: 58$ & $2,572.13$ & Calibrated Electric Tape & Nearest Tenth Foot & USGS & $4,311.57$ & $1,314.17$ \\
\hline $7 / 19 / 2005$ & $12: 11$ & $2,569.75$ & Calibrated Electric Tape & Nearest Tenth Foot & USGS & $4,313.95$ & $1,314.89$ \\
\hline $7 / 18 / 2005$ & $13: 00$ & $2,580.08$ & Electric Tape & Nearest Foot & SNJV & $4,303.62$ & $1,311.74$ \\
\hline $5 / 31 / 2005$ & $4: 15$ & $2,601.50$ & Interpreted from Geophysical Logs & Not Nearest Foot & SNJV & $4,282.20$ & $1,305.21$ \\
\hline $5 / 30 / 2005$ & 9:45 & 2,604 & Interpreted from Geophysical Logs & Not Nearest Foot & SNJV & $4,279.70$ & $1,304.45$ \\
\hline $5 / 29 / 2005$ & $12: 00$ & 2,619 & Interpreted from Geophysical Logs & Not Nearest Foot & SNJV & $4,264.70$ & $1,299.88$ \\
\hline $5 / 29 / 2005$ & $4: 00$ & 2,654 & Interpreted from Geophysical Logs & Not Nearest Foot & SNJV & $4,229.70$ & $1,289.21$ \\
\hline $3 / 9 / 2006$ & $12: 37$ & 914.96 & Calibrated Electric Tape & Nearest Tenth Foot & USGS & $5,968.74$ & $1,819.27$ \\
\hline $12 / 6 / 2005$ & $14: 38$ & 917.01 & Calibrated Electric Tape & Nearest Tenth Foot & USGS & $5,966.69$ & $1,818.65$ \\
\hline 9/22/2005 & $12: 38$ & 915.97 & Calibrated Electric Tape & Nearest Tenth Foot & USGS & $5,967.73$ & $1,818.96$ \\
\hline $7 / 26 / 2005$ & NA & 916.47 & Calibrated Electric Tape & Nearest Tenth Foot & SNJV & $5,967.23$ & $1,818.81$ \\
\hline $7 / 19 / 2005$ & 13:15 & 916.23 & Calibrated Electric Tape & Nearest Tenth Foot & USGS & $5,967.47$ & $1,818.88$ \\
\hline
\end{tabular}

aSurface elevation: 6,883.7 ft amsl

Source: NNSA/NSO, 2006; USGS/DOE, 2006

NA $=$ Not available

$\mathrm{m}=$ Meter 
depth-deviation information recorded with the EMI logs (see Appendix A) below 2,200 ft indicates that the borehole is deviated 1 to 3 degrees vertical from 2,200 to 3,000 ft bgs, and that the deviation increases up to over 11 degrees from 3,000 ft to TD. The known deviation between 2,200 $\mathrm{ft}$ and the water level at about 2,570 ft bgs requires a $-0.26 \mathrm{ft}$ correction for true vertical depth for water-level measurements. A full-depth deviation log would be required to determine the total correction from the ground surface for deviation. The estimated correction above is not included in the reported water-level information.

Figure 2-1 shows a graph of the ER-12-4 main completion water-level measurements, and Figure 2-2 shows a graph of the ER-12-4 piezometer measurements (USGS/DOE, 2006). The water levels shown are rounded per the specified accuracy in Table 2-1. The water level for the ER-12-4 main completion trended upward immediately following completion and stabilized in the period during testing; it appears to be in equilibrium since testing. The ER-12-4 piezometer has been stable over a range of about $1 \mathrm{ft}$ during the same period.

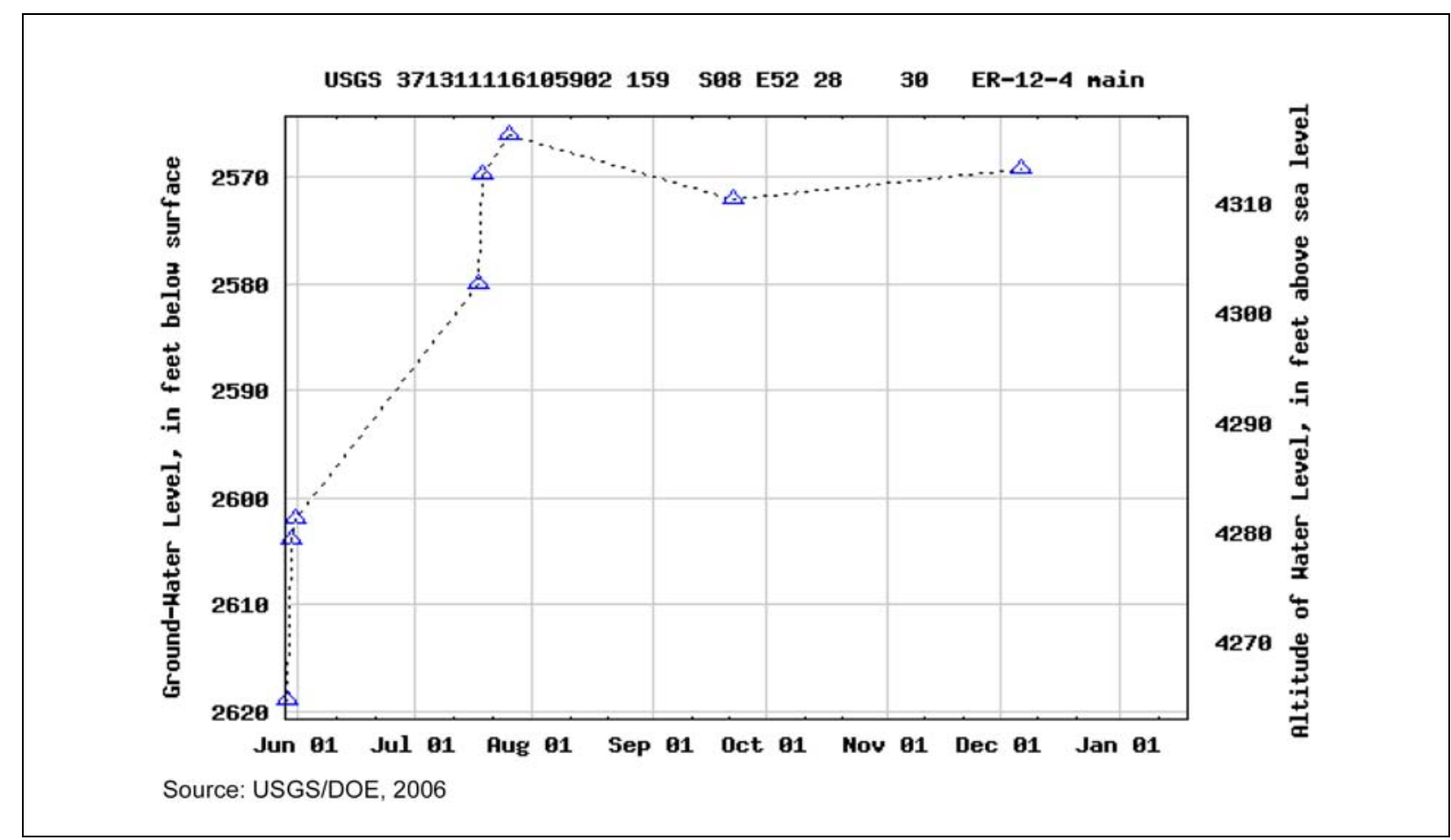

Figure 2-1

ER-12-4 Main Completion Water Levels 


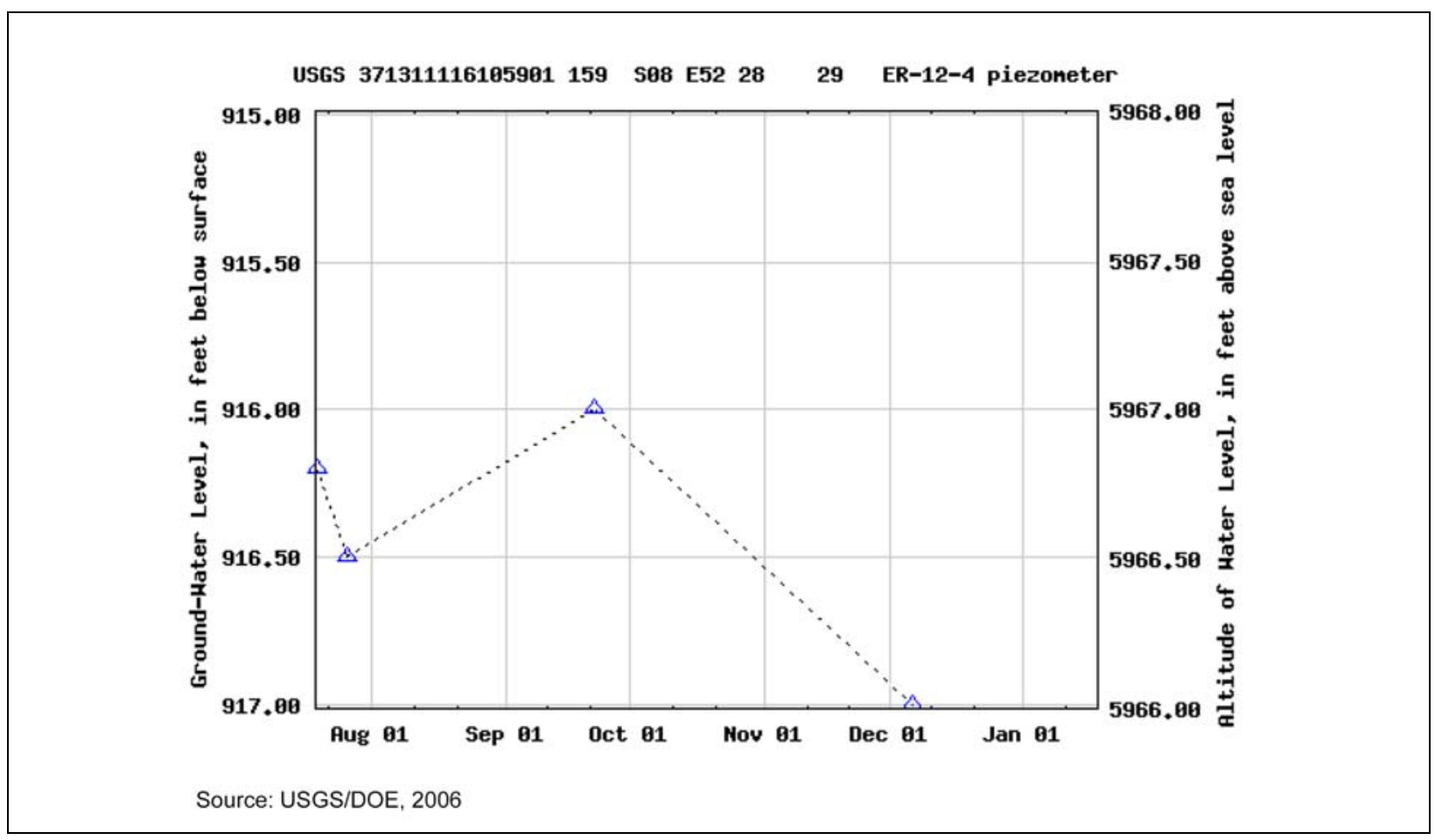

Figure 2-2

ER-12-4 Piezometer Water Levels

\subsubsection{Continuous Water-Level Monitoring}

Continuous water-level monitoring records were recorded in both completions during the testing program. However, the period of record before pumping began in the main completion indicated that the well was not in equilibrium, and the recovery obscured any background water-level trend. The post-pumping record was terminated before recovery to equilibrium was achieved.

No effects of pumping are observed in the continuous water-level monitoring record for the piezometer (see Figure 2-6, SNJV, 2005c), which may be expected because the piezometer appears to monitor a perched water table. Both the continuous records and discrete water-level measurements appear to show relatively stable water levels.

\subsubsection{Vertically Discrete Water-Level Measurements}

Water-level measurements representing equilibrium were not made during drilling of ER-12-4 that would provide information on the vertical head distribution in the upper volcanic units and for the gradient within the LCA3 section. There is a very substantial head difference between the piezometer 
completion and the main completion. The water level is about 1,610 ft higher in the overlying volcanic units than in the LCA3. The two completions are separated by a cement seal $276 \mathrm{ft}$ long (see Figure 1-3) located in the TCU. The piezometer completion (open annulus) is open across all the upper volcanic units (including the WTA, VTA, and TCU HGUs), but the bottom of the open annulus (top of cement) is substantially above elevation of the top of the LCA3. The water level in the piezometer is in the VTA unit just above the top of the TCU. Because the water level represents an average of the individual heads for each unit weighted by the transmissivity $(T)$ of the respective unit, the location of the VTA suggests that the formation through the entire open interval of the piezometer completion below the water level is saturated. The large head difference between the piezometer and main completion indicates that the TCU has very low vertical hydraulic conductivity $(\mathrm{K})$ and that vertical flow from the TCU to the LCA3 is probably very low. This is also reflected in the LCA3 water level (main completion) below the top of the LCA3, indicating that vertical flow is insufficient to saturate the upper part of the LCA3 formation.

The main completion in the LCA3 is also open for almost the full depth of the LCA3 penetration, and the water level within the completion is below the top of the LCA3, resulting in an apparent unsaturated condition in the top of the unit. Consequently, the piezometer head is interpreted to reflect "perched" water in the TCU/VTA, and does not indicate a continuous vertical gradient with the LCA3. To some extent, vertical gradient in the LCA3 may be interpreted based on natural flow in the borehole or well completion, which is discussed in Section 2.2.

\subsection{Flow in the Well Under Natural Gradient}

The interpretation of temperature logs can be used in conjunction with downhole flow measurements for identification of flow patterns in the well. This applies both to the ambient, equilibrium condition and during pumping. The downhole flow and temperature data are evaluated in this section to interpret natural-gradient flow and identify implications for conditions in the formation. The data for the pumping condition are evaluated in Section 3.3. The natural-gradient condition provides the baseline for interpretation of the pumping condition data. The flow and temperature data are interpreted at face value without discounting information that is unusual or confusing, but without accounting necessarily for all features. The interpretation is not definitive but is offered as a 
framework for understanding the hydrology at this location based on the data collected. Further data collection may be required to confirm or discount implications of this interpretation.

\subsubsection{Non-Pumping Temperature Profiles}

Figure 2-3 shows the overlay of three temperature profiles and one flow profile, superimposed on a schematic indication of the vertical extent of the slotted casing intervals in the production casing. The slotted intervals (individual slotted joints of casing) are alternated with unslotted joints of casing across the interval 3,111.4 to 3,668.7 $\mathrm{ft}$ bgs to provide access to the annulus of the well completion which is open to the formation from 2,501 ft bgs (762.3 m bgs) (above the water level in the LCA3 to a TD of 3,715 ft bgs [1,132.3 m bgs]). Along the left side of the diagram is a schematic indication of the occurrence of open fractures in the borehole and possible faults, as determined by Fronterra Integrated Geosciences (Leavitt, 2005) from interpretation of the EMI log that was run after drilling was completed. These fracture picks are preliminary and have not been confirmed by UGTA staff. However, the primary objective here is to indicate the vertical density of fracturing, which appears qualitatively representative in review. Open fractures appear to occur regularly along the borehole below the static water level, throughout the slotted interval(s).

Temperature increases with depth approximately linearly, reflecting the geothermal gradient which is approximately linear in formations with homogeneous thermal conductivity not affected by advective heat transport or significant localized heat sources (e.g., intrusives). Temperature profiles measured in water-filled boreholes should be similar to the geothermal gradient, but can be modified by vertical movement of water in the borehole due to various factors such as temperature differences, hydraulic gradients, and $\mathrm{K}$ variations. Temperature profiles can be evaluated based on changes in gradient with depth and with respect to changes between profiles logged under differing borehole conditions such as ambient borehole circulation versus during pumping.

Figure 2-3 shows the ambient borehole temperature profile, which was observed in the open borehole shortly after drilling. The temperature profile in the borehole at the time of this logging may not have been in complete equilibrium with the formation to yield a truly "ambient" temperature profile but is believed to present an good approximation. The profile is used to represent the formation temperature profile relative to later temperature profiles that appear to be affected by natural flow in the borehole. Typically, a borehole temperature profile substantially affected by drilling would have 


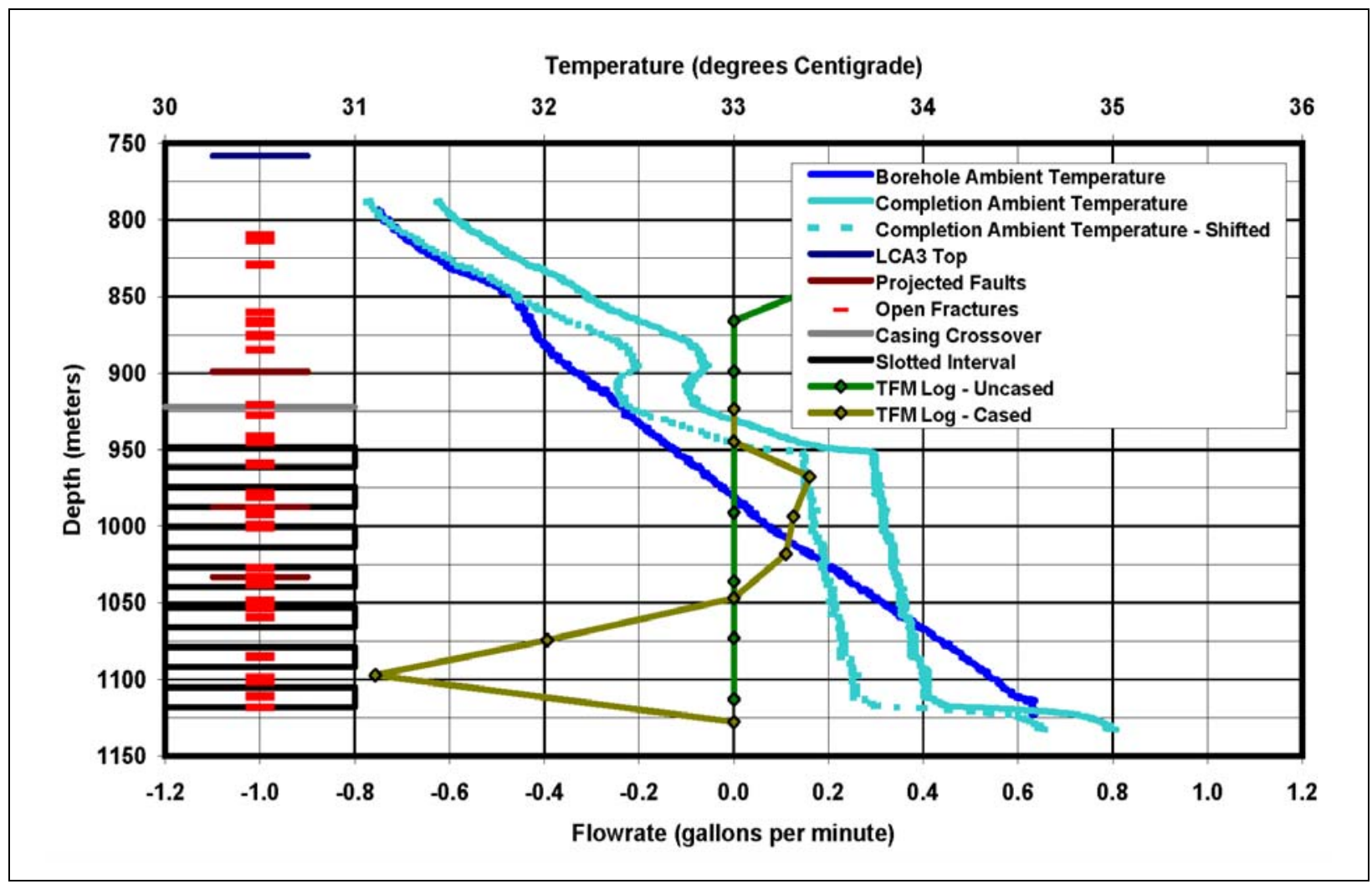

Figure 2-3

\section{Ambient Temperature and Flow Profiles for ER-12-4}

been closer to isothermal. The “ambient” temperature profile indicates an almost linear thermal gradient from the water level in the borehole to TD. The actual ambient temperature profile may be warmer than this log indicates because drilling at this time of year typically results in cooling of the borehole with drilling fluids colder than subsurface temperatures. The temperature logs that are compared in this analysis were run with the DRI ChemTool. Comparison of the temperature logs must allow for some uncertainty in the absolute calibration of the tool at each time.

The well completion was then installed (see Figure 1-3), which placed casing within the borehole that was slotted across seven intervals (see Figure 2-3, slotted intervals). Subsequent temperature logs were run within this completion. The completion ambient temperature log shown was run at the end of development. It must be considered that logs run in the well completion reflect changing relationships of the logged water column with conditions in the annulus, depending upon whether the logging tool is within a slotted interval or within blank casing. Water interchange with the annulus can occur within the slotted intervals, but only flow between slotted intervals occurs within the blank 
completion casing. Temperature in the annulus may have an effect on the temperature profile in the blank casing through heat conduction across the casing.

The temperature profile within the cased well is changed substantially from the uncased borehole. The temperature profile in the well completion is a fraction of a degree Celsius $\left({ }^{\circ} \mathrm{C}\right)$ warmer but approximately parallel to the borehole temperature profile above a depth of $950 \mathrm{~m}$ bgs, the top of the uppermost slotted interval, except for a positive excursion between 850 to $950 \mathrm{~m}$ bgs. The small temperature difference may be a calibration discrepancy. The cased-well log is also shown shifted by $-0.37^{\circ} \mathrm{C}$, labeled as Completion Ambient Temperature - Shifted, so that it matches the borehole ambient temperature log at the top and bottom of the log as well as at the depth of the crossover. The shift of this log is based on the assumption that the temperature difference is a calibration discrepancy. From about 950 to 1,120 m bgs, across the entire slotted interval, the temperature profile is linear and almost isothermal, suggesting inflow of water at one temperature, at about 1,025 m bgs where the cased temperature profile crosses the borehole temperature profile. The cased temperature profile shows minor cooling as water flows upward and minor warming as it flows downward. Below the lowermost slotted interval, the temperature increases back to the borehole ambient temperature. Above the top of the slotted interval, the cased temperature profiles drops back to the ambient temperature profile. The positive temperature excursions above the top of the slotted interval both drop back to the ambient profile in the proximity of fractures, probably indicating that the upward flow is entering the formation at the fractures.

During the development program, the well was pumped extensively. Pumping may have changed borehole conditions substantially, cleaning the fractures of residual drilling fluid, which affected the natural circulation in the well by opening the fracture K. An interpretation of the nature of the change between the open borehole temperature log and the ambient temperature log in the well completion is that the fractures were initially plugged with residual drilling fluid/cuttings, and there was little flow in the well because of the consequent low $\mathrm{K}$ of the fractures. After development, increased $\mathrm{K}$ of the fracture intervals would allow substantial circulation in the well driven by the natural head differences between the fracture intervals, modifying the temperature profile. Temperature profiles are discussed within the context of natural flow in the well in Section 2.2.3. 


\subsubsection{Non-Pumping Flow Logs}

Figure 2-3 also shows the uncased and cased Thermal Flow meter (TFM) measurements. The uncased TFM measurements were made before well completion and correspond to the borehole ambient temperature profile. These measurements indicate very low flow rate in the borehole upwards in the uppermost part of the borehole, above $900 \mathrm{~m}$ bgs. The well was still equilibrating at this time, so the upward flow may reflect the water level rise during equilibration, and the distribution of flow indicates that the inflow to the borehole is in the area of the uppermost projected fault and uppermost fracturing. The lack of substantial flow in the borehole suggests that the ambient borehole temperature measured profile was not significantly affected by borehole circulation and reflects the geothermal gradient. The cased TFM measurements shown were made at the end of recovery after development. These measurements indicate upward flow in the upper half of the completion, above $1,050 \mathrm{~m}$ bgs, and downward flow in the lower half of the completion.

\subsubsection{Flow Interpretation}

The completion ambient temperature profile crosses the borehole ambient temperature profile in the range of 1,025 to 1,060 $\mathrm{m}$ bgs (Figure 2-3). This indicates inflow to the well at this depth (through the corresponding slotted interval) of water at the temperature of the borehole ambient temperature profile, moving both upward and downward, which is consistent with the TFM log (cased) showing uphole flow above this depth, and downhole flow below. Above the uppermost slotted interval, water appears to re-enter the formation around $925 \mathrm{~m}$ bgs, where the temperature drops to the borehole ambient temperature. Below the lowermost slotted interval, the downward flow appears to re-enter the formation, and the temperature log indicates no flow below as the temperature increases quickly to the borehole ambient temperature. Above the uppermost slotted interval, the temperature drops quickly back to the borehole ambient temperature. The flow pattern suggests that the head in the area of inflow, corresponding to the lowest projected fault and associated fracturing, may be higher than above and below. However, there are no other data to support this.

\subsection{Barometric Efficiency}

The barometric efficiency (BE) of the well is used to remove head variation in the water-level monitoring records, particularly for analysis of the constant-rate test, produced by barometric 
pressure variation, which are unrelated to the test. The importance of determining the correct value for $\mathrm{BE}$ is somewhat dependent on the magnitude of the drawdown of the well during testing; the greater the drawdown, the less influence the barometric correction has on the measured formation response. For ER-12-4, the water-level changes that occurred during pumping were large compared to the small-scale changes resulting from barometric pressure variation, and the removal of barometric pressure variation is not critical to an accurate analysis of the response to pumping. Barometric efficiency is determined from analysis of the correlation of head variations in continuous water-level monitoring records and barometric pressure variation. Because the primary use of BE is for removing the effect of barometric pressure variation, it is treated as a fitting parameter for maximum smoothing of records.

\subsubsection{Barometric Efficiency Analysis}

The methodology used for determining BE, as a fitting parameter, consists of overlaying the water-level record with the barometric pressure record after converting barometric data to consistent units and inverting the trace (according to the negative correlation). The processed barometric trace is trended and scaled until a best-fit match to the water-level record is determined. The trending represents water-level trends not related to barometric response allowing the barometric component of the water-level record to overlay the barometric record; the scaling factor is equal to the BE. This method assumes that the water level in the well is in equilibrium with the groundwater head, and that trends are linear. Good results from this method require that the record includes changes in barometric pressure longer-term than semidiurnal fluctuations, with magnitude substantially greater than those fluctuations. These conditions are necessary to separate the barometric response of the well from earth tide-related fluctuations and to avoid phase-shift uncertainty of short-term barometric responses.

Initial analysis of BE was reported in Section 3.1 of the data report for hydraulic testing for monitoring records using both the best-fit method outlined above and the Clark method (SNJV, 2006b). The short monitoring records and the non-linear trend in the record for the main completion due to equilibration of the water level (Section 2.1.1) resulted in substantial uncertainty in determining BE values. Non-linear trends are not compatible with either method used for analysis. The monitoring records have been re-evaluated, and portions of records were selected for best 
characteristics for analysis. The best fit for the ER-12-4 main completion was obtained with BE of 0.75 (Figure 2-4) using a late-time, short portion of the record with one barometric pressure excursion where background non-linear equilibration was minimal. The ER-12-4 piezometer records are not amenable to analysis for BE. The early record is dominated by non-linear equilibration, and the later record does not include any substantial barometric excursions. The BE appears to be in the range of 0.8 to 1.0, but this result is uncertain. These values for BE are approximate due to the limitations of the short records noted above, and would introduce an unquantified uncertainty if used in direct analysis of formation hydraulic properties. A more accurate value for BE would require a water-level monitoring record that meets the requirements stated in the first paragraph of this section.

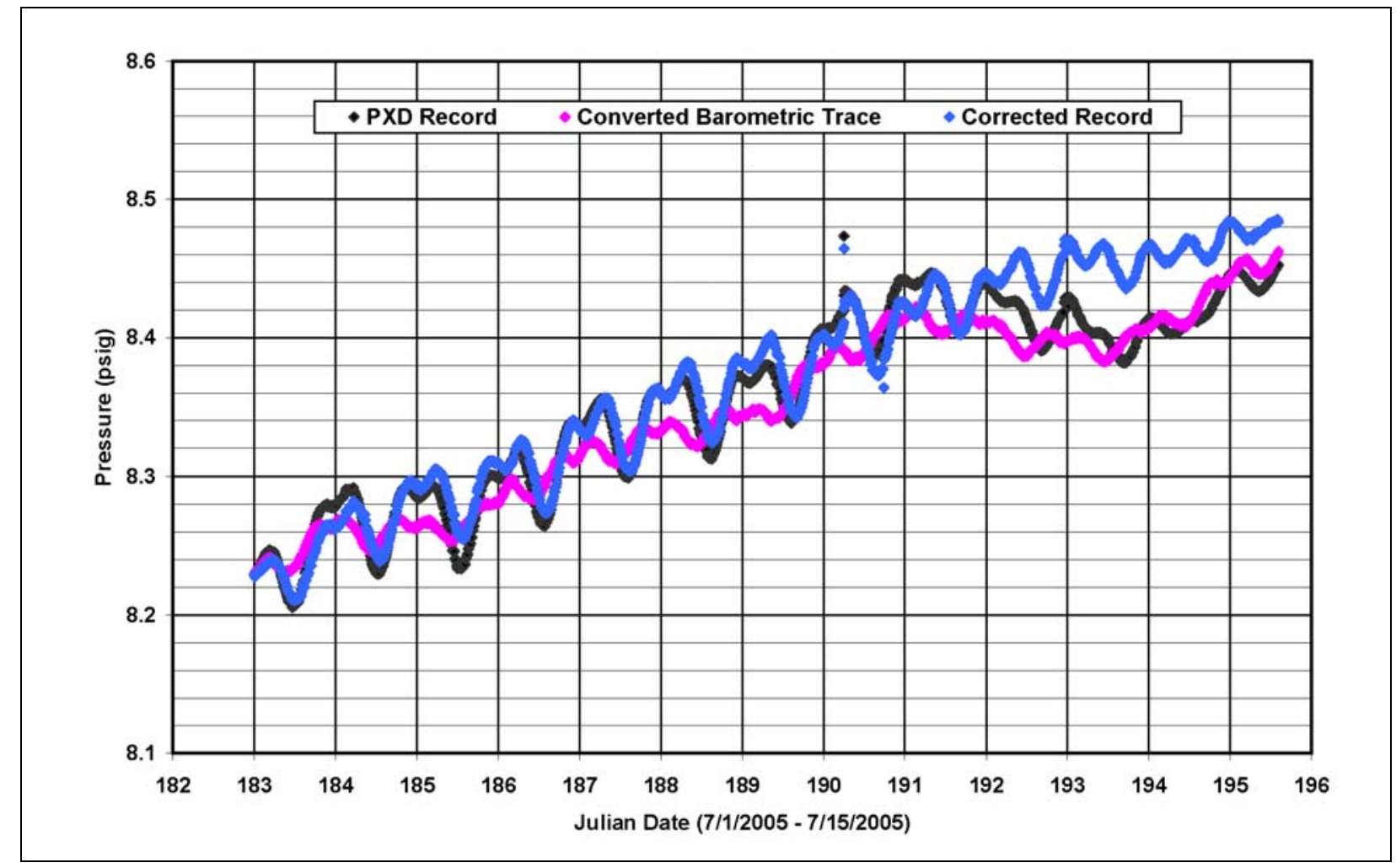

Figure 2-4

Barometric Efficiency for ER-12-4 Main Completion

\subsubsection{Static Formation Head Versus Static Water Level}

Static formation pressure measured as the head of the water column surface within the well is equivalent to the composite equilibrium pressure of the formation(s) accessed by the well completion. The well completion effectively connects varying pressure within the formation, resulting in 
formation static pressure that is the integrated average of the varying pressure weighted by the associated $\mathrm{K}$. The static formation pressure represents the starting head for the pressure response to hydraulic stress, and the head that recovering formation pressure approaches with time.

In practice, the static formation pressure is difficult to characterize for several reasons: 1) head measurements are made at the water surface in the well rather than within the production interval, 2) variable density along the water column with depth due to temperature variation and water-quality variation results in uncertain estimation of the formation head at the completion interval, and 3) natural ambient flow driven by pressure gradients within the well alters the pressure distribution. In the case of ER-12-4, these factors are not well known due to the inability to make continuous measurements of flow and temperature in the annulus where these measurements would reflect the formation directly. The discontinuous nature of the completion within the long, open annulus, and the complex interaction of production from the formation with the completion, make interpretation difficult. The uncertainty resulting from these factors cannot be resolved because sufficient information is not available. These factors during pumping and the associated uncertainties are discussed in Section 3.0. 


\subsection{Pumping Well Hydraulics}

This section evaluates pumping-well hydraulics and presents an analysis of the pumping-response testing. The recorded well response to pumping can be affected by barometric pressure changes during the test, earth tides, and background water-level trends. These factors are evaluated to determine whether corrections to the record are required. Well losses and effects of temperature changes in the well during pumping are also evaluated. Pumping hydraulics are assessed to determine whether the magnitude of well losses requires corrections to attribute the correct proportion of the drawdown to the formation response. In cases where there are substantial temperature profile changes in the water column resulting from pumping, the magnitude of the temperature change effect on the observed water-level change must be considered in analysis. After analysis of the pumping test to determine the composite transmissivity $(\mathrm{T})$ of the formation tested, the discrete production distribution measured through flow logging may be used to determine the hydraulic conductivities (Ks) of distinct flow intervals of the formation.

\subsection{Pumping-Response Records}

This well was not very productive, and pumping rates of 10 to 25 gallon per minute (gpm) produced large drawdowns. Consequently, during the development and testing period for this well, the pump was cycled on and off during the day and remained off at night to allow recovery. A long-term constant-rate test could not be performed because the drawdown at the lowest pumping rate was excessive during extended pumping. The pump that was installed after the testing/development program for long-term sampling could operate at lower production rate. For the sampling effort in April and May 2006, the well was purged at a constant-rate of 4.4 gpm for a period of over 4.5 days. The drawdown response was monitored during this period and provides the best hydraulic test information obtained for this well. Limitations are that there was not a check valve in the production tubing, and the initial pumping rate until a stable total dynamic head was achieved higher than the constant-rate, and that the initial recovery response was affected by backflow of the production tubing water column into the well. 


\subsection{Processing of the Water-Level Monitoring Record}

The raw pumping response record may be processed in several ways to render a more accurate record of the actual formation response to pumping. This may entail removing effects of barometric pressure changes during the test, both short-term for smoothing the record, and long-term for gross changes in barometric pressure during the test. Additional processing may be employed to remove earth tides, background water-level trends, well losses, and temperature profile change effects. Commonly, the response is recorded as pressure changes (of the water pressure of the water column above a pressure tranducer [PXD]) and is converted to water-level changes by multiplying the pressure changes by a conversion factor for water density derived from pressure versus depth measurements made during PXD installation. However, the ER-12-4 analysis was conducted using recorded pressure changes directly.

\subsubsection{Background Water-Level Monitoring Record}

A background monitoring record was recorded in ER-12-1 during the ER-12-4 testing program. The record reflects water level changes in the uppermost zone in that well, which is completed in an interval of CA (probably related to the LCA3), but is not mapped as continuous with the LCA3 in ER-12-4. Such a record may be used for removal of background water-level trends and/or earth tides. It is not clear that this well can necessarily be expected to provide a representative background response. The record for ER-12-1 (see Figure 2-3, SNJV 2006b) shows a continuous increasing head trend during the period of testing, which is not evident in the ER-12-4 records. Well ER-12-3 would have been the most likely candidate for a background record; however, monitoring at this well was discontinued before testing operations began at ER-12-4, at which time the well had not yet equilibrated following testing. There was no background monitoring of any nearby well during the April and May 2006 sampling effort.

\subsubsection{Barometric Pressure Changes and Earth Tides}

Barometric pressure changes during the development and testing period and during constant-rate pumping for sampling were not great enough with respect to the drawdown observed to require that the record be processed to remove the barometric effects. The record of barometric pressure changes during the development and testing period is shown in Figure 2-8 of the Rainier Mesa Well ER-12-4 
Data Report for Well Development and Hydraulic Testing (SNJV, 2006b). The record of barometric pressure changes during the constant-rate pumping for sampling period is shown in Figure 2-8 of the Well ER-12-4 Preliminary Data Report for Submersible Pump Installation and Groundwater Sampling (SNJV, 2006c). Earth tides were not significant with respect to the drawdown response and also were not smoothed or removed.

\subsubsection{Background Water-Level Trends}

Background water-level trends were not removed from the records. Clear definition of any such trend was not available from data collected. The background water-level record from ER-12-1 during the ER-12-4 development and testing period indicates there was a trend in that well, but it is not clear that it is applicable to ER-12-4. In any case, the indicated trend would not make a large difference to the analysis of that period. The pre- and post-test records were also insufficient to ascertain trends because of the water level equilibration taking place during the record period.

There was no background monitoring during the April and May 2006 sampling episode. There also was no pre-test monitoring to determine any background trend. The post-pumping record primarily reflects the continuing recovery. The post-test monitoring was terminated before complete recovery, and any background trend superimposed on the recovery is not separable. A qualitative evaluation of the available records does not suggest that any substantial trend, relative to the magnitude of the drawdown response, was occurring. The incomplete recovery from development pumping was incorporated in the analysis of the constant-rate test by way of incorporating the development pumping in antecedent conditions.

\subsubsection{Well Losses}

Well losses due to friction losses in the well, entrance losses for the slotted intervals, and losses for upward flow to the pump in the production casing may be accounted for using analysis of step-drawdown tests or other means to estimate such losses. The importance of accounting for such losses depends on the magnitude of such losses relative to the measured response. The magnitude of friction losses is proportional to the square of the flow velocity and the length of the flow path. For ER-12-4, the low pumping rate relative to the slotted-interval length and production casing diameter results in fairly low flow velocities within the well, and the distance of flow from the entrance into the 
slotted casing to the pump was, on average, slightly over $300 \mathrm{ft}$. These factors would result in fairly low well-friction losses.

The step-drawdown tests did not produce consistent results, probably due to the inequilibrium starting point of each test sequence and the slow equilibration of the well to changes in production rate relative to the length of pumping at each step. The results in general indicate that the non-linear part of the losses is probably quite low, which was expected, and correction of the pumping response data for well losses was not considered necessary.

\subsubsection{Effects of Temperature Profile Changes}

Formation pressure is commonly monitored with a PXD located near the water surface rather than in the completion interval for practical reasons. The water-surface elevation reflects the formation pressure as a function of the water density in the water column. The water-column density may vary as a result of temperature and water-quality variation. When the density profile is constant, the water-surface elevation varies linearly, with respect to the formation pressure, after accounting for secondary components of the responses, such as barometric pressure variation and earth tides. However, pumping the well can alter the temperature profile as a result of moving water from the completion interval to the surface replacing both water in the water column below the pump intake and conduction of heat above the pump intake. After pumping has begun, the temperature profile will approach a new equilibrium; and after pumping ceases, the profile will equilibrate back to the ambient profile. The volume expansion (or contraction) as temperatures increase (or decrease) affects the water-surface elevation independent of the formation pressure changes, and the effect can be significant when temperature changes are large and/or the water-column length long. Borehole temperature profiles were logged intermittently during development, both under ambient conditions and at multiple pumping rates, and then again following recovery and the testing program. The temperature shift from the ambient to the pumping condition was not great (compare produced water temperatures, see Figure 3-14). The temperature effect on the pumping response was not considered great enough to warrant correction of the record before analysis.

Water-quality variation affecting the water-column density may result from suspended sediment in the water column and/or gas entrainment in the water, due to air removal from the formation from 
drilling production and to exsolving gas from depressurizing the water. However, no information was collected to provide understanding of these factors, and they are assumed to have a negligible effect.

Density variation that occurs in the water column above the PXD does not affect the PXD pressure measurement used to measure the well response to stress. If formation pressure were measured at the depth of the completion interval, changes in water-column density would not affect measurement of formation pressure changes, and these effects of temperature change would not be a problem in analysis.

\subsection{Pumping-Test Analysis}

Two separate pumping episodes were conducted at ER-12-4 during FYs 2005 and 2006. The first episode was conducted between June 22 and August 22, 2005; and included well development, spinner flow logging, water sampling, and hydraulic testing (SNJV, 2006b). The second episode was conducted for the purpose of purging the well before sampling and took place between April 21 and 26, 2006 (SNJV, 2006c). For the remainder of this section, the two pumping episodes will be referred to as the "FY 2005 test" and the "FY 2006 test."

The FY 2005 test was comprised of eight short duration pumping periods separated by slightly longer duration recovery periods (Figure 3-1) and a longer duration recovery period after the last pumping period. (All figures for Section 3.0 are found at the end of the section.) The pumping periods were of short duration because of excessive drawdown in the well even at the lowest pumping rate the installed pump could be operated. Figure 3-1 is a composite plot of the pressure and flow rate during the FY 2005 development and testing period. The pumping/recovery cycles were analyzed using the n-Dimensional Statistical Inverse Graphical Hydraulic Test Simulator (nSights) V. 2.20 well-test interpretation program. It was not possible to assess the conceptual model based on the longer-term evolution of the drawdown response with any confidence due to the complicated nature of the test sequence and short-period pumping cycles.

The second ER-12-4 hydraulic drawdown response record was recorded during the period April 21 to 26, 2006 (Figure 3-2). Drawdown was monitored during a single pumping period while the well was purged before collecting water samples. After cessation of the five-day pumping period, the water level recovery in the well was monitored for 50 days. Complicating the analysis of this dataset are the 
lack of a continuous flow rate record during pumping, and the absence of a check valve in the test string.

The following sections describe the method, conceptual model, analysis, and results for the ER-12-4 single-well pumping test drawdown and recovery responses. Section 3.5 follows with the interpretation and analysis of measured discrete production from flow logging.

The nSights well-test interpretation program was used to generate log-log diagnostic plots and estimate the formation properties. The nSights program was developed by INTERA, Inc. for Sandia National Laboratories (SNL) based on the well-test analysis code GTFM (Graph Theoretic Field Model), the nSights precursor. Field use for GTFM has a long history including the Swiss, Swedish, and French nuclear waste programs, as well as at the DOE Waste Isolation Pilot Plant in New Mexico (Roberts et al., 1999). A description of the governing equations used in both codes is found in Pickens et al. (1987). Following SNL Nuclear Waste Management Program Procedure NP19-1, “Software Requirements," Rev. 4, nSights was verified to meet NQA-2 requirements (ASME, 1990). Verification was documented through comparison to the analytical solutions for constant-rate pumping tests (Theis, 1935), constant drawdown tests (Lohman, 1972), slug tests (Cooper et al., 1967), and pulse tests (Bredehoeft and Papadopulos, 1980). The nSights program is complete with a suite of statistical routines that support the identification and quantification of parameter sensitivity and uncertainty.

The nSights program uses a numerical approach to simulate radial/non-radial groundwater flow through a confined, single-phase, single-porosity or dual-porosity, one-dimensional (for this analysis) flow domain in response to boundary conditions (i.e., pumping rate changes) applied at the production well. The flow domain is discretized into a system of concentric rings centered on the borehole that uses a multiplicative factor to increase the spacing between rings with increasing distance from the borehole. Each ring is represented by a node; hence, the radial symmetry.

The nSights program can simulate transient flow and pressure responses, which vary in accordance to the imposed boundary condition at the well. The nSights program is a numerical simulator; therefore, all combinations of inner boundary conditions (constant rate, constant pressure, and non-constant rate and pressure) may be sequentially simulated without the need for restarts. This feature allows simultaneous simulation of complex hydraulic test sequences that otherwise, using conventional 
analytic analysis techniques, would need to be split into individual events. The advantage of this approach is that the set of estimated parameters are consistent for an entire test sequence.

\subsubsection{Method of Analysis}

The analysis of pressure/head transient data takes a step-wise approach:

1. Identify the conceptual flow model.

2. Estimate initial parameter.

3. Execute inverse process.

4. Evaluate uncertainty.

The conceptual flow model is evaluated by the use of log-log diagnostic plots (Horne, 1995). The pressure data and pressure derivative diagnostic plot aids in identifying characteristic responses of flow regimes, and identifies how changes through time define characteristics of the well/reservoir or aquifer system (Horne, 1995). For example, a typical log-log diagnostic plot of a constant rate drawdown test will exhibit an early-time response characteristic of the well (wellbore storage and skin factor), a middle-time response characteristic of the aquifer (stable derivative for a homogeneous aquifer), and a late-time response characteristic of outer boundaries (up turned derivative for no-flow and down turned derivative for constant head boundaries). Likewise, fracture flow, dual porosity, and closed boundaries all have characteristic shapes when displayed in the log-log diagnostic plot format. Thus, diagnosis of the conceptual model defines the parameters that must be estimated in the analysis. It should be noted that, in actual testing scenarios, the three flow regimes (inner boundary, reservoir response, and outer boundary) may not be readily observed in a diagnostic plot, due to complicating factors typical of any field test. In the case where no definitive model can be identified, the simplest model which best represents the measured data and hydrogeologic environment is always chosen.

To provide a starting point for the nSights inverse modeling, it is useful to "rough in" a fit to the measured data. This is accomplished by estimating the $\mathrm{T}$ from the diagnostic plot if possible, otherwise nSights is run in the forward mode, and the T and storativity (S) and other model parameters are adjusted by the analyst until an approximate fit to the measured data is achieved. These "ballpark" simulations function to provide a reasonable initial guess at the fitting parameters. Otherwise, nSights could fail to converge to a solution if the initial guess at the fitting parameters are 
too far from the actual values. From the diagnostic plot, the T may be estimated from the radial flow portion of the data via the expression:

$$
T=Q / 4 \pi m
$$

where $Q$ is the flow rate during the drawdown period and $m$ is the value of the stabilized derivative during radial flow.

The inverse model for the ER-12-4 test was set up in nSights by inputting all of the test-specific information. This information includes the well completion information; the test interval length; the fluid data; and the formation data (i.e., the conceptual model specific parameters [initial parameter estimates, T, S, etc.] and the numerical parameters [outer boundary radius and number of nodes]).

Also, input into nSights are the measured pressure data and flow rate data; the durations or starting times of the pumping and recovery periods; and finally, the specific data, termed "data constraint," to which nSights will compare the simulated response and minimize the difference of the measured and simulated data.

With the inverse model properly set up, test runs are executed to ensure that nSights can converge to solution, and that the solution makes sense with regard to the measured data. These troubleshooting simulations are necessary because they establish a set of base case parameters from which the perturbation analysis originates. The perturbation analysis is a large set $(>100)$ of inverse runs that are consecutively executed where the starting values of the fitting parameters are randomly perturbed from their base-case values and nSights estimates a new set of parameters for each perturbation. The purpose for such an analysis is to gain an understanding of the uncertainty in the fitting parameters. When post-processed, a series of plots and descriptive statistics are developed that facilitate evaluation of the goodness of fit; and hence, the uncertainty in the parameter estimates.

\subsubsection{Conceptual Model and Initial Parameter Estimates}

The FY 2005 test had a number of complicating factors (number, duration and varying rate of the pumping periods) that made the construction of meaningful diagnostic plots for model identification impractical. As a result, the recovery period of the FY 2006 test was used for model diagnosis even though it, too, suffered from non-ideal conditions. The largely unknown and widely fluctuating rate 
during the pumping period combined with the absence of a check valve in the test string increased the uncertainty of any conceptual model identified using the FY 2006 test recovery data. Nonetheless, these FY 2006 test recovery data provide the best choice for model identification for the ER-12-4 test interval.

Figure 3-3 is a diagnostic plot of the FY 2006 test recovery period. The early-time trends in the delta pressure and derivative, slope greater than 1 , and the derivative crossing over the delta pressure reflect changing wellbore storage as the water in the tubing string drains back in the test interval. The wellbore storage coefficient for an open-hole pump test such as the ER-12-4 test is a cross-sectional area of flow (i.e., the cross-sectional area of the well where the water level is changing). Thus, during the pumping period, the cross-sectional area is the area of the production casing minus the area of the tubing string. However, for the early time of the recovery period, the water level is changing both in the production casing and in the tubing string, and this effect is readily observed in Figure 3-3.

Further impact of the water draining out of the tubing back into the test interval on the measured data is the dampened sinusoidal trend observed in the pressure derivative (Figure 3-3). This sinusoidal trend was probably caused by the oscillation of the water levels in the tubing string and production casing, respectively, and does not reflect a complex formation hydraulic response. An additional complication is the appearance of the large "hump” observed in the derivative at about 0.05 days. This hump occurs at a time that is typical for a skin effect around the well; however in this case, it could be a combination of a skin effect with water-level oscillations. It is not possible to determine from FY 2006 test data whether it is due to skin effect or oscillating water levels; therefore, skin was included in the nSights model.

The middle time data, which provide information about the aquifer proper, appear to be reaching stabilization (i.e., infinite-acting radial flow). Although these recovery data were overprinted with effects of the tubing draining back into the test interval, it still appeared as if the derivative was tending toward a constant value indicative of radial flow and a homogenous aquifer model.

The late-time data of the diagnostic plot (Figure 3-3) do not show any obvious boundary effects, but rather variation in the late-time derivative reflects an increased noise band in the measured data as the pressure recovered closer to the static level. No outer boundary was considered in the nSights model of the ER-12-4 test. 
Based on the 2006 test recovery period diagnostic plot, the conceptual model used in the ER-12-4 nSights model was comprised of wellbore storage and skin factor with a homogeneous aquifer of infinite lateral extent. To provide a starting point for the nSights simulations, the $\mathrm{T}$ was estimated based on the stabilized portion of the derivative from the diagnostic plot (Figure 3-3). Table 3-1 provides a summary of the input values and calculated $T$ value.

\section{Table 3-1}

Estimated Transmissivity for the FY 2006 ER-12-4 Hydraulic Test

\begin{tabular}{|c|c|c|c|}
\hline Stress Period & $\begin{array}{c}\text { Flow Rate } \\
(\mathbf{g p m})\end{array}$ & $\begin{array}{c}\boldsymbol{m}^{\mathbf{a}} \\
(\mathbf{p s i})\end{array}$ & $\begin{array}{c}\mathbf{T} \\
\left(\mathbf{f t}^{2} / \mathbf{d}\right)\end{array}$ \\
\hline \hline F02 & 4.4 & 11.9 & 2.4 \\
\hline
\end{tabular}

avalue of the stabilized derivative

psi $=$ Pounds per square inch $\mathrm{ft}^{2} / \mathrm{d}=$ Square feet per day

Based on the estimated T value reported in Table 3-1, a formation T value of $2.4 \mathrm{ft}^{2} / \mathrm{d}$ was used as the initial value for the nSights inverse modeling. The other fitting parameters included formation storativity, the skin radius, skin storativity, and skin factor. The formation $\mathrm{P}$ was also set as a fitting parameter in the analysis. This was necessary because pre-test water-level monitoring data were not collected, and the water level had not fully recovered to static conditions by the end of the recovery period.

\subsection{3 nSights Inverse Model}

The pumping and recovery period for the FY 2006 ER-12-4 hydrologic testing was defined in nSights based on the measured pressure and flow-rate data as reported in the Well ER-12-4 Preliminary Data Report for Submersible Pump Installation and Groundwater Sampling (SNJV 2006c) and the accompanying dataset.

Well ER-12-4 was pumped from April 21, 2006 (Julian day 111) until April 26, 2006 (Julian day 116), at an average rate of $4.4 \mathrm{gpm}$. Unfortunately, continuous flow rate measurements were not collected during the first three days of the test due to an equipment problem. During the first several hours of pumping, flow rate was recorded manually by field staff, and these data were appended to the electronically collected data for a more complete flow rate record. The flow rate data were used in nSights to generate a function of flow rate versus time using linear interpolation between data 
points. Pumping was halted on April 26, 2006 (Julian day 116), and pressure recovery data were collected for 50 days until June 15, 2006 (Julian day 166).

The nSights program uses non-linear regression to minimize the difference between the simulated test response and the measured test data constraint by adjusting the initial values of the fitting parameters up or down until a set of convergence criteria are met. A set of formation hydraulic parameters are defined in nSights that provide a best-fit simulated response to the measured data. Transmissivity, S, initial pressure $(\mathrm{P})$, and the skin factor parameters were defined as the fitting parameters in the ER-12-4 analysis. The data constraint used in the analysis was the entire measured Cartesian pressure history.

Based on the results of the FY 2006 test analysis, an nSights model of the FY 2005 test was set up using the same conceptual model and the parameters estimated from the FY 2006 test as initial values. The FY 2006 test was set up in accordance with the information provided in Rainier Mesa Well ER-12-4 Data Report for Well Development and Hydraulic Testing (SNJV, 2006b). The well development period was set up in nSights as a flow period where the measured flow rate data were used as input. Because the PXD record after removal of the PXD for flow logging was not aligned with the early PXD record, and there was insufficient information to align them, the two flow periods could not be analyzed together. The post-flow logging period was set up as separate flow and recovery periods, and the pressure was matched in nSights.

To gain an understanding of the uncertainty in the fitting parameters, perturbation analyses were set up for both the FY 2005 and FY 2006 tests. The results are discussed in Section 3.3.4.

\subsubsection{Best-Fit Parameter Estimates and Uncertainty}

The results of the 500-run perturbation analyses for the FY 2006 ER-12-4 hydraulic test were evaluated based on the value of the objective function (i.e., the sum of squared errors [SSE]). The SSE ranged from 33,000 to 35,000 for the FY 2006 test with 34,000 set as the upper limit of SSE, which eliminated two of the 500 fits.

Figure 3-4 is a Cartesian horsetail plot of the measured pressure and the nSights simulations for the FY 2006 test. Compared to the recovery period, the fit to the pumping period of the FY 2006 test is 
relatively poor. Possible reasons for the degradation in the fit are data errors such as lack of high quality flow rate and/or pressure measurements or a misdiagnosed conceptual model. Both could lead to the lower quality of fit to the pumping period data. Attempts were made to improve the overall fit by trying a series of runs using different constant flow rates, as well as changing the conceptual model by including the flow dimension as a fitting parameter; neither of these strategies improved the fit. Thus, short of trying different conceptual models randomly or performing additional hydraulic testing, it was not feasible to continue fitting the ER-12-4 data. While changing the conceptual model would have a minimal effect on the T, a change in the flow rate could markedly change the T estimate.

The values of the model parameters (T, S, P and skin factor) resulting from the FY 2005 and FY 2006 test perturbation analyses are tabulated in Table 3-2. Figure 3-5 is a plot of SSE versus T and shows that $\mathrm{T}$ is confined to a very small range of values between 2.3 and $2.8 \mathrm{ft}^{2} /$ day (Table $3-2$ ). Static formation pressure was also estimated with high confidence as shown in Figure 3-6 where it is plotted as a function of $\mathrm{T}$. This figure shows the tendency for pressure to be negatively correlated with $\mathrm{T}$, and despite the correlation both parameters maintain high confidence. Figure 3-7 is a plot of S versus T and shows that while $\mathrm{T}$ is limited to a small range, $\mathrm{S}$ varies over several orders of magnitude. The $\mathrm{S}$ varies over a broad range of values as does the skin factor (Figure 3-8). This is due to the correlation of these parameters, which leads to non-unique values of storage and skin factor. Figure 3-8 is a plot of skin factor versus S that clearly illustrates this correlation. The negative values of the skin factor reflect enhanced flow in the region of the well (i.e., a zone of higher $\mathrm{T}$ in the near wellbore region).

Table 3-2

Estimated Parameters for the ER-12-4 Hydraulic Test

\begin{tabular}{|c|c|c|c|c|c|c|c|c|}
\hline \multirow{2}{*}{ Test } & \multicolumn{2}{|c|}{$T\left(f^{2} / d\right)$} & \multicolumn{2}{|c|}{$\mathbf{S}^{\mathbf{a}}$} & \multicolumn{2}{|c|}{$P(p s i)$} & \multicolumn{2}{|c|}{ Skin Factor ${ }^{a}$} \\
\hline & Minimum & Maximum & Minimum & Maximum & Minimum & Maximum & Minimum & Maximum \\
\hline FY 2005 & 6.3 & 10.4 & $3 E-10$ & $2 \mathrm{E}-07$ & 143.4 & 145.9 & -6.4 & -2.5 \\
\hline FY 2006 & 2.3 & 3.0 & $8 E-10$ & 9E-06 & 180.7 & 182.2 & -8.4 & -3.2 \\
\hline
\end{tabular}

aUnitless

For the FY 2005 test perturbation analysis, the SSE term ranged from 37,000 to 166,000 with the fit degrading above SSE values of 40,000. The results of the perturbation analyses are based on those runs for which the SSE was less than 40,000, which included 350 of the 500 perturbations. 
Figure 3-9 is a Cartesian horsetail plot of the FY 2006 test comparing the best-fit simulations (SSE $<40,000)$ to the measured pressure data. The overall fit of the simulated data to the measured data is good.

Figure 3-10 is a plot of the SSE versus T for the FY 2005 test. The values used to define the T range are plotted in red and those excluded are in blue. Figure 3-10 shows that T varies from about 6.3 to $10.4 \mathrm{ft}^{2} / \mathrm{d}$. The color-mapped plot of static formation pressure versus T (Figure 3-11) shows the negative correlation between $\mathrm{P}$ and $\mathrm{T}$ and the how the best fits, those with the lowest SSE values, are constrained above $T$ values of about $8 \mathrm{ft}^{2} / \mathrm{d}$.

Both the plot of S versus T (Figure 3-12) and skin factor versus S (Figure 3-13) reflect the uncertainty in the storage term and the insensitivity of the simulated response to large variations in storage. Interestingly, the analysis of the FY 2006 test provides a negative skin factor value, which further confirms the presence of enhanced flow in the neighborhood of the borehole.

Table 3-2 provides the minimum and maximum values of the fitting parameters resulting from the perturbation analyses for the conceptual model for both the FY 2005 and FY 2006 tests. The range of estimated $\mathrm{T}$ from the two tests varies by a factor of about five, which is a relatively small range, and lends confidence to the analysis. The S estimate varies over 3 to 4 orders of magnitude.

The static pressure (head) was also a fitting parameter and is reported as pressure in Table 3-2. The estimated static pressure cover a range, which corresponds to 3 to $6 \mathrm{ft}$ of head. Table 3-3 provides the depth-to-water values for the FY 2005 test calculation based on the pressure values (Table 3-2) and the calculated PXD depth values provided in Table 2-5 of the ER-12-4 well development report (SNJV, 2006b). No calculation of the depth to the PXD was provided for the FY 2006 test; therefore, depth-to-water was not calculated. There was no compensation made for changes in fluid density due to temperature effects at depth.

As reported in Table 2-5 of the ER-12-4 data report (SNJV, 2006b), the calculated depth to the PXD transducer was 2,889.1 ft bgs at the start of hydraulic testing and 2,887.3 ft bgs at the completion of testing. The difference in these values may be attributed to temperature changes during testing and 
Table 3-3

Depth-to-Water

\begin{tabular}{|c|c|c|c|c||}
\hline \multirow{2}{*}{ Test } & \multirow{2}{*}{$\begin{array}{c}\text { Pressure } \\
\text { (psi) }\end{array}$} & $\begin{array}{c}\text { Head } \\
\text { (ft) }\end{array}$ & \multicolumn{2}{|c|}{$\begin{array}{c}\text { Depth-to-water } \\
\text { (ft bgs) }\end{array}$} \\
\cline { 4 - 5 } & & & Initial & Final \\
\hline \hline FY 2005 & 143.4 & 330.4 & $2,558.6$ & $2,556.9$ \\
\hline FY 2005 & 145.9 & 336.2 & $2,552.9$ & $2,551.2$ \\
\hline FY 2006 & 180.7 & 416.4 & N/A & N/A \\
\hline FY 2006 & 182.2 & 419.8 & N/A & N/A \\
\hline
\end{tabular}

measurement inaccuracy related to the great depth of the borehole. The values for depth-to-water in Table 3-3 are within about $10 \mathrm{ft}$ of those reported in Table 2-2 of the ER-12-4 well development report (SNJV, 2006b), which lends confidence to the nSights estimated pressure values.

The conceptual model (wellbore storage and skin factor in a homogeneous aquifer of infinite lateral extent) used in the ER-12-4 hydraulic test analysis provides high confidence estimates of T, and relatively high confidence estimates of static pressure. The estimates of $\mathrm{S}$ and skin factor, on the other hand, are relatively low confidence because of the correlations discussed above. An additional model that included fitting on the flow dimension was attempted with similar results in terms of skin factor and storage. This model was discarded because it unnecessarily complicated the model without increasing the parameter confidence.

\subsection{Interpretation and Analysis of Measured Discrete Production}

The production profile in the well can be evaluated using both flow logging and temperature logging during pumping. Flow logging may be interpreted quantitatively while temperature logging is qualitative. Neither of these logs directly reflects the production distribution in the formation because the configuration of the ER-12-4 completion does not provide continuous access to the formation. The flow logs indicate the flow profile within the well completion string of slotted and blank casing, which localizes the observed production to the intervals of slotted casing, and shows flow between the slotted intervals. However, the arrangement of alternating screens do provide somewhat consistent, generalized information on the distribution of production due to the regular pattern of alternation. The temperature logs measure temperature in the water column within the well 
completion. However, the temperature profile within the well completion reflects the flow in the well modified by the temperature distribution in the annulus behind the completion casing through heat conduction, which reflects flow in the annulus.

\subsubsection{Temperature Profiles During Pumping}

Figure 3-14 shows a representative temperature profile during pumping overlaid on the ambient temperature profiles previously discussed. Allowing for some temperature calibration uncertainty for the log, the pumping profile is almost identical to the ambient profile except for a difference in slope across the uppermost slotted interval, suggesting that the greater proportion of pumping inflow to the well is in this interval. Inflow from the formation is probably at about 1,025 m bgs. The profile indicates continued downward flow in the lower part of the well during pumping.

\subsubsection{Flow Logging During Pumping}

The flow logs collected during production in this well are not typical, exhibiting large fluctuations in flow through the alternating slotted intervals and blank casing, which vary depending upon the logging direction (up or down). It appears that trolling the logging tool caused circulation within the completion casing with the annulus through the slotted intervals. Examples of the flow logs are found in Figures 2-14 and 2-15 of SNJV (2006b). The flow logs were evaluated in detail by the DRI (Oberlander and Russell, 2005), and quantitative analysis of the logs is discussed. This document should be consulted for a thorough review of the flow logging information. General conclusions from this document are used in the descriptive analysis of the well hydraulics during pumping. The conclusion offered is that the "change in borehole flow rate under pumping conditions was limited to the upper portion of the well screen.” Examination of Figure 7 of that document indicated the apparent change is above about 3,280 ft bgs (1,000 m bgs). There does not appear to be a good basis for more quantitative results. This is somewhat consistent with the analysis of the temperature log in the previous subsection.

\subsubsection{Hydraulic Conductivity Estimates}

Hydraulic conductivity can be calculated from the T by dividing by aquifer thickness, (i.e., the thickness of the formation that the test response is deemed to represent). This can be considered in several ways depending upon the nature of the representation of hydraulic properties required. 
Several types of aquifer thicknesses can be defined, and the resultant estimates of $\mathrm{K}$ are listed in Table 3-4. As a function of the open annulus behind the completion casing, pumping stress is applied to the entire length of the borehole from the static water level to the bottom of the borehole. The aquifer thickness can be considered to be the entire formation access interval from the static water level to the TD of the well. However, natural vertical hydraulic gradient in the well can affect the applied stress distribution in the well. The natural vertical head gradient in this well is unknown. However, the applied stress (drawdown) is large, a maximum of about $246 \mathrm{ft}$ in the FY 2005 test and about $267 \mathrm{ft}$ in the FY 2006 test. If the applied stress is much larger than the natural vertical head gradient, the effect of the natural vertical head gradient would be proportionately small.

Table 3-4

Hydraulic Conductivity Estimates

\begin{tabular}{|c|c|c|c|c|}
\hline \multirow{2}{*}{ Parameter } & Description & $\begin{array}{c}\text { Aquifer } \\
\text { Thickness } \\
\text { (ft) }\end{array}$ & Minimum & Maximum \\
\hline \hline $\mathrm{T}\left(\mathrm{ft}^{2} / \mathrm{d}\right)$ & FY 2005 Test Analysis Result & N/A & 6.3 & 10.4 \\
\hline \multirow{2}{*}{$\mathrm{K}(\mathrm{ft} / \mathrm{d})$} & Total Formation Access Interval & 1,145 & 0.006 & 0.009 \\
\cline { 2 - 5 } & Apparent Production Interval & 580 & 0.011 & 0.018 \\
\hline $\mathrm{T}\left(\mathrm{ft}^{2} / \mathrm{d}\right)$ & $\mathrm{FY} 2006$ Test Analysis Result & $\mathrm{N} / \mathrm{A}$ & 2.3 & 3.0 \\
\hline \multirow{2}{*}{$\mathrm{K}(\mathrm{ft} / \mathrm{d})$} & Total Formation Access Interval & 1,145 & 0.002 & 0.003 \\
\cline { 2 - 5 } & Apparent Production Interval & 580 & 0.004 & 0.005 \\
\hline
\end{tabular}

Flow and temperature logging (discussed in Section 3.4) indicate the part of the borehole from which water was produced as a result of pumping, which was apparently less than the total formation access interval of the well. Reflecting the flow and temperature logging information, a more representative $\mathrm{K}$ may be defined for the interval from the static water level to the depth below which there does not appear to be any production. The temperature log indicated this depth at about 3,149 $\mathrm{ft}$ bgs, and the flow logging analysis indicated this depth at about 3,248 ft bgs. The depth of 3,149 ft bgs based on the temperature log was used to calculate a minimum aquifer thickness for water production. Fracturing appears to be generally distributed along the borehole, and the logs do not clearly indicate water production associated with specific fracturing, so an aquifer thickness specific to fracturing intervals was not defined. 
Table 3-4 lists estimates of the $\mathrm{K}$ for the two different aquifer thickness values based on the T estimates from the nSights analysis listed in Table 3-2. The results show the range of $\mathrm{K}$ values resulting from the uncertainty in the test analysis and different assumptions for aquifer thickness.

\subsection{Summary}

The LCA3 formation in this well was much less productive compared to other wells producing from the LCA3, with very large drawdown relative to the pumping rate, especially considering the long formation access interval and the density of fracturing observed in the fracture logs. With the fracturing well distributed along the borehole, $\mathrm{K}$ along the formation would also be expected to be well distributed. However, the fracturing generally does not result in substantial hydraulic conductivity. It appears that most of the production is from one depth associated with only a few identified fractures.

In view of the downward flow observed in the lower part of the well under non-pumping conditions, the low productivity suggests that a substantial vertical head gradient must exist to drive that flow. Consequently, the apparent limited productive interval in the borehole and continuing downhole flow during pumping suggest that the vertical gradient across the formation access interval exceeded the drawdown during pumping.

The hydraulic test was interpreted in terms of $\mathrm{T}$. Conversion of $\mathrm{T}$ to $\mathrm{K}$ requires that the formation thickness be identified. For this well, selection of an appropriate formation thickness depends upon the type of representativeness for the $\mathrm{K}$ value that is desired and the assumptions that are made about production from the formation. An interpretation is offered in Section 3.4.3 for the production intervals; however, other interpretations are possible. The $\mathrm{T}$ can be assigned to formation intervals according to the particular needs of the analysis, and $\mathrm{K}$ determined as a variable for different intervals or as an average for the entire completion interval. 


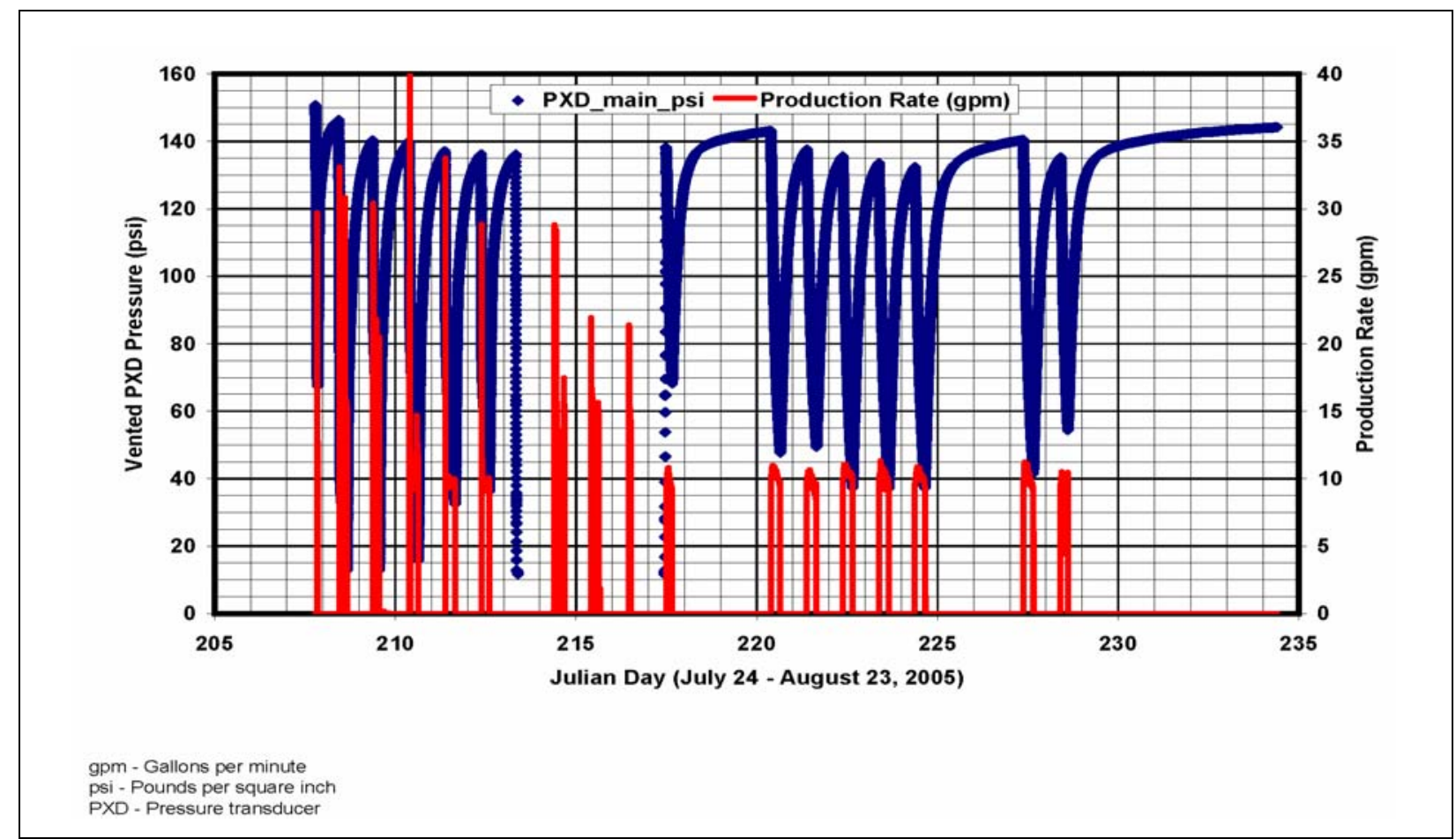

Figure 3-1

Composite Plot of Pressure and Flow Rate for the FY 2005 Test

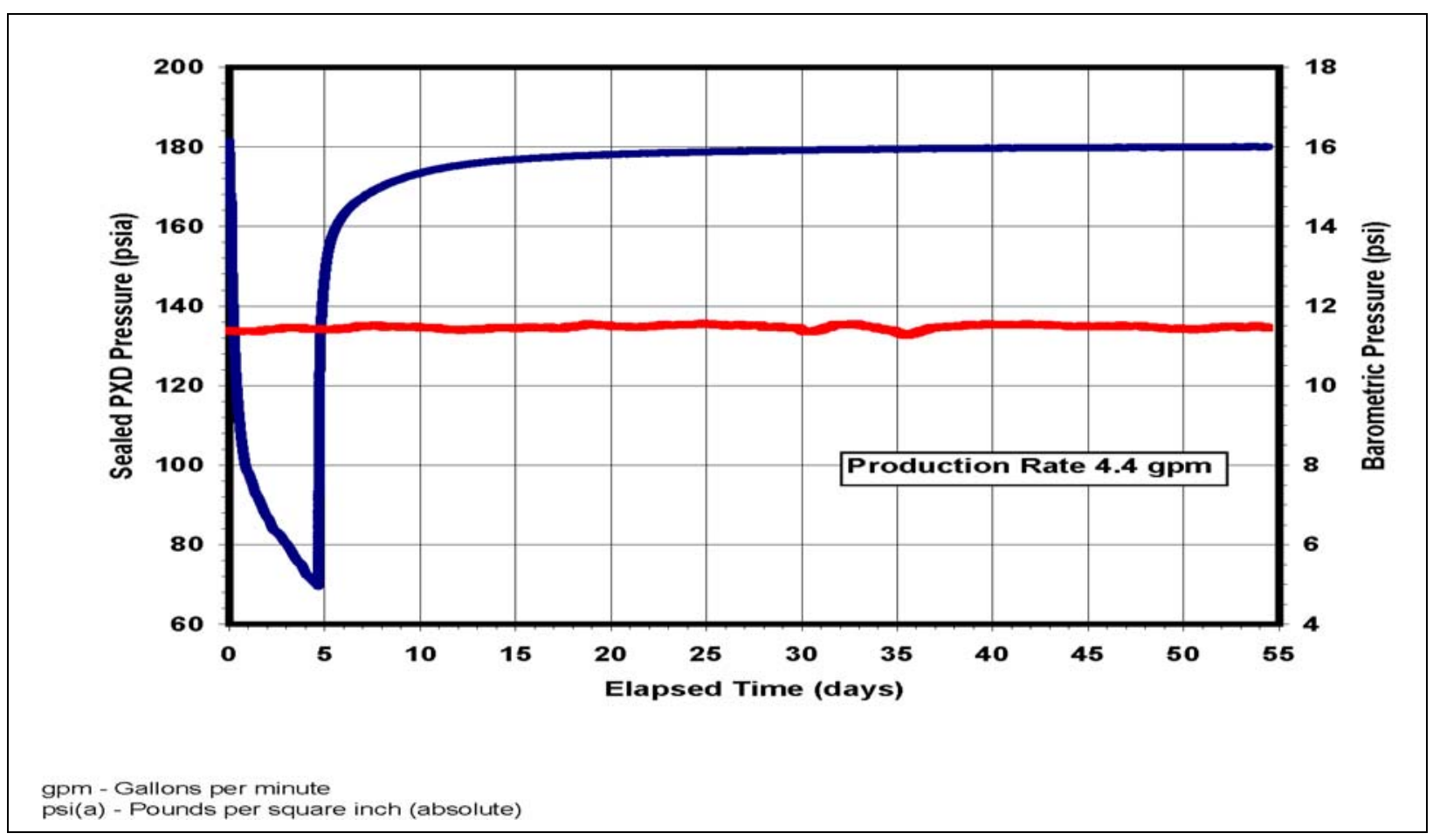

Figure 3-2

Composite Plot of Pressure and Flow Rate for the FY 2006 Test 


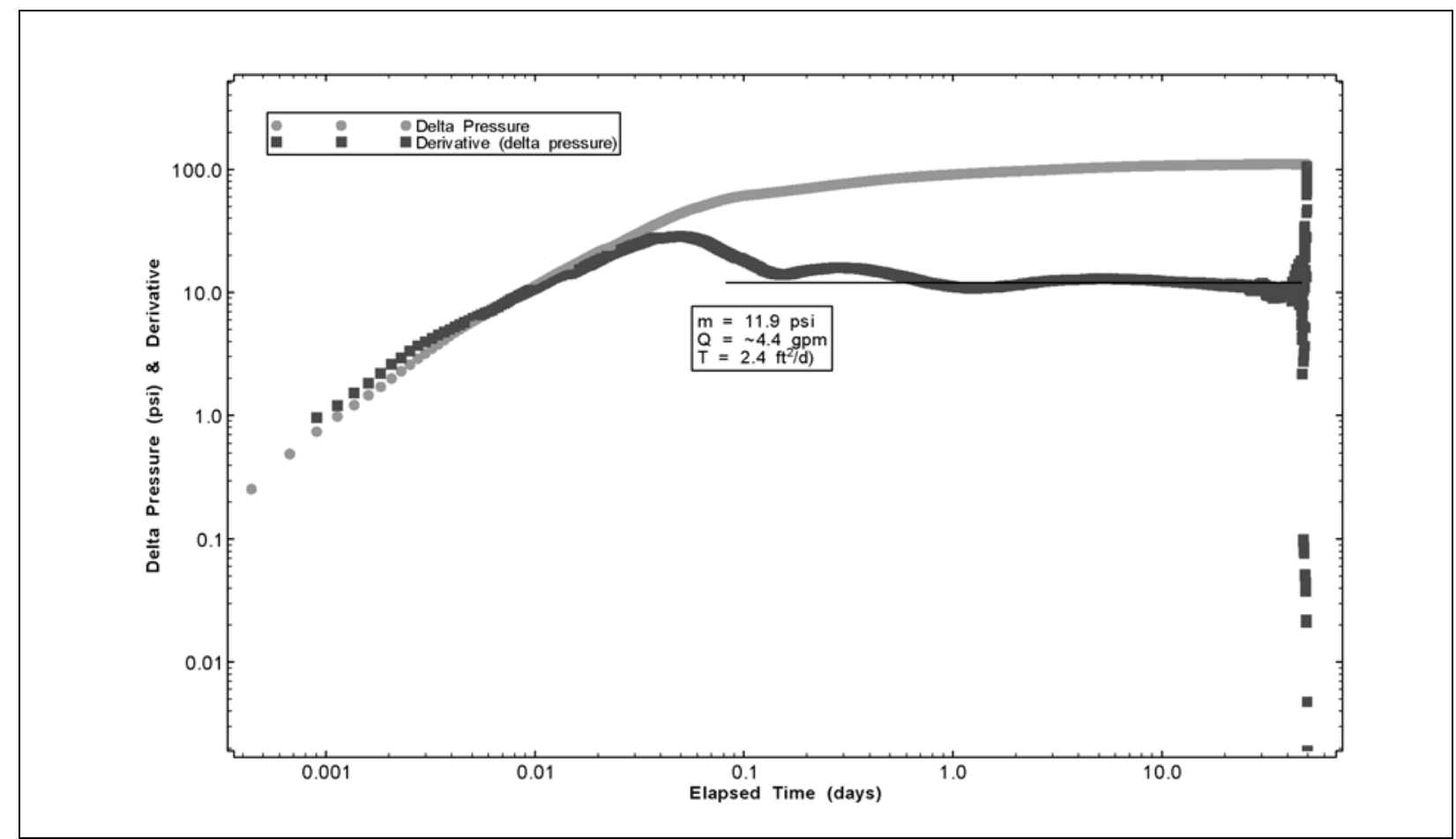

Figure 3-3

Diagnostic Plot of the FY 2006 Recovery Showing Stabilized Derivative

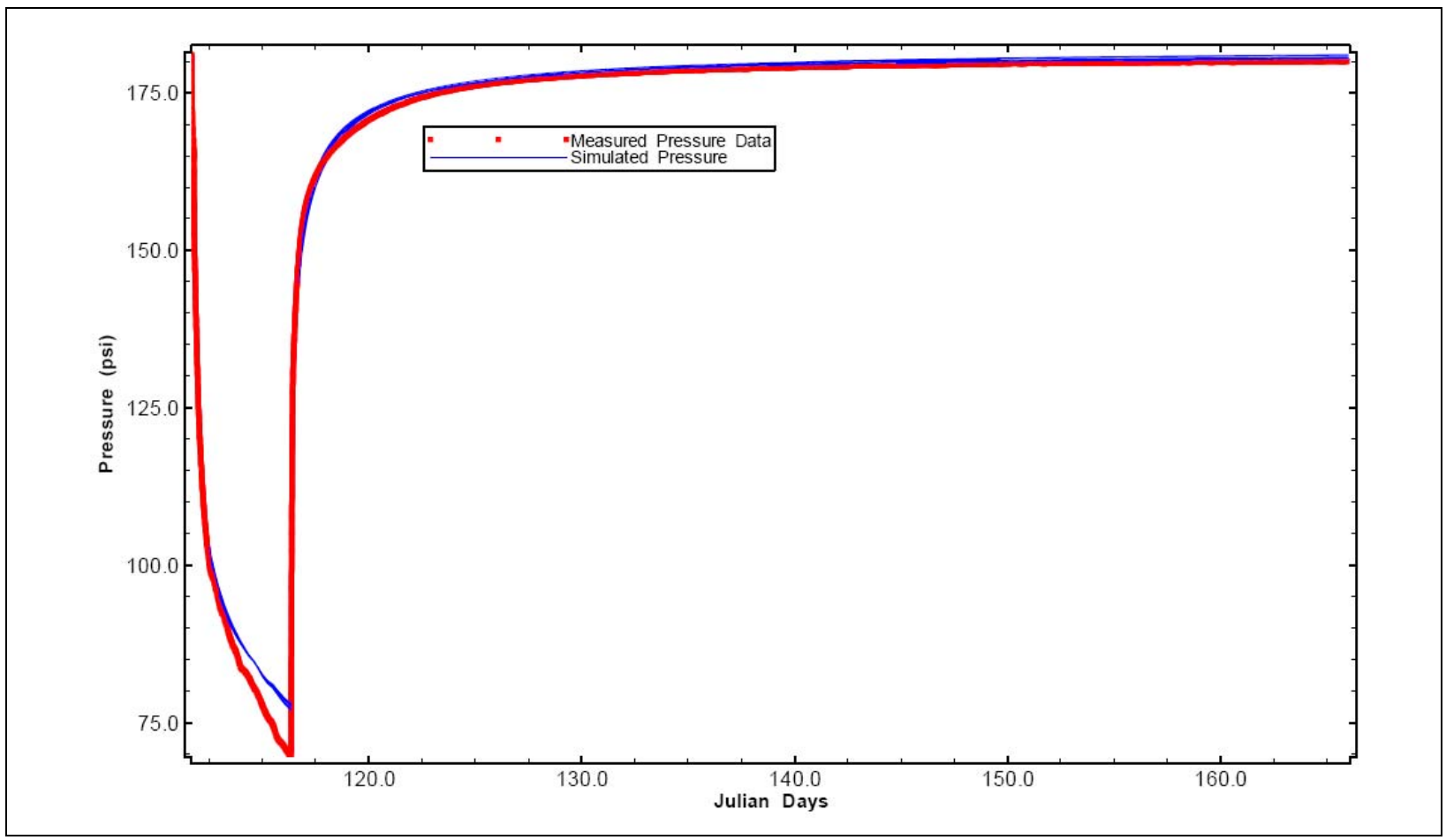

Figure 3-4

Cartesian Horsetail Plot for the FY 2006 Test 


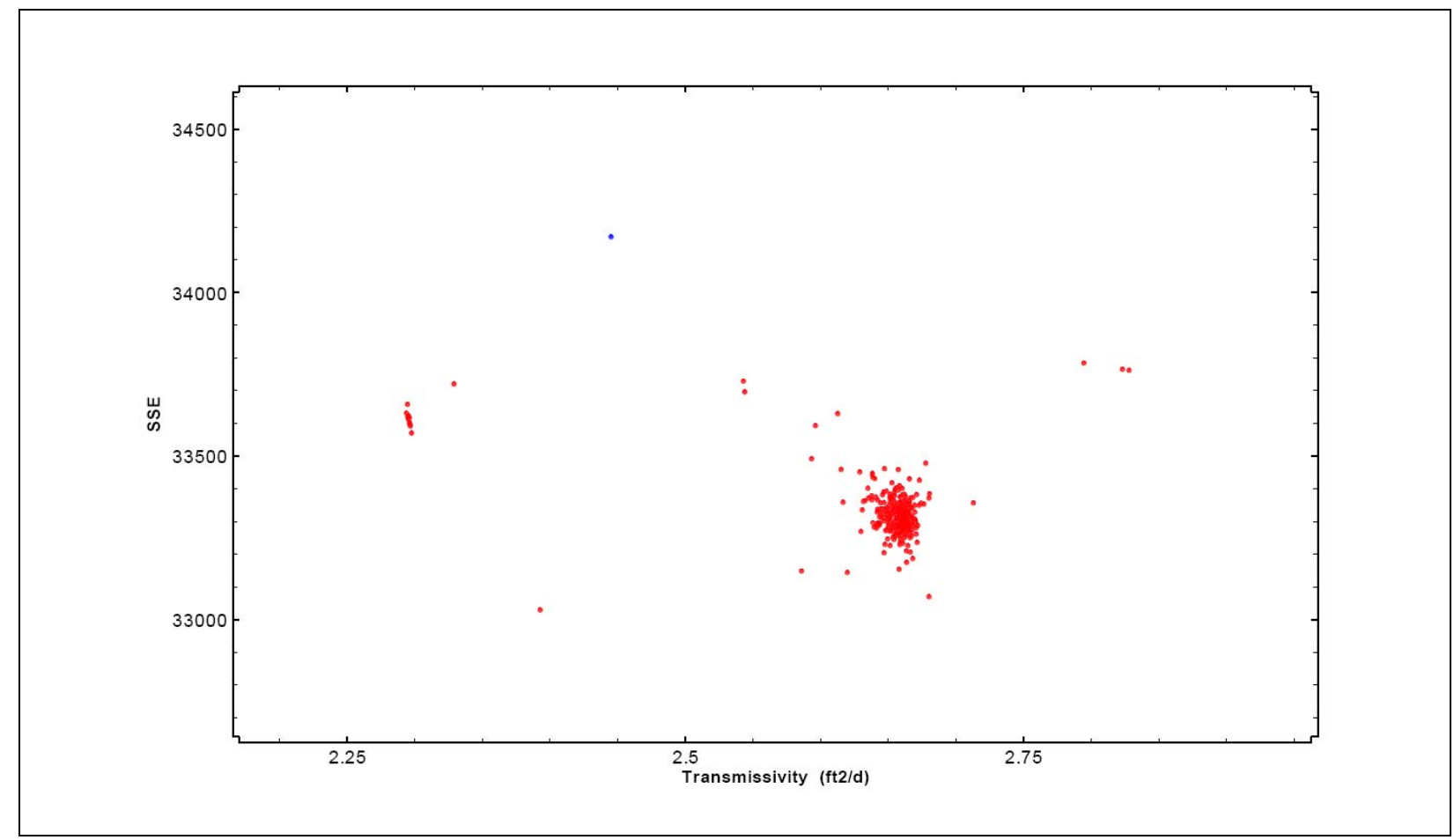

Figure 3-5

Plot of SSE Versus Transmissivity for the FY 2006 Test

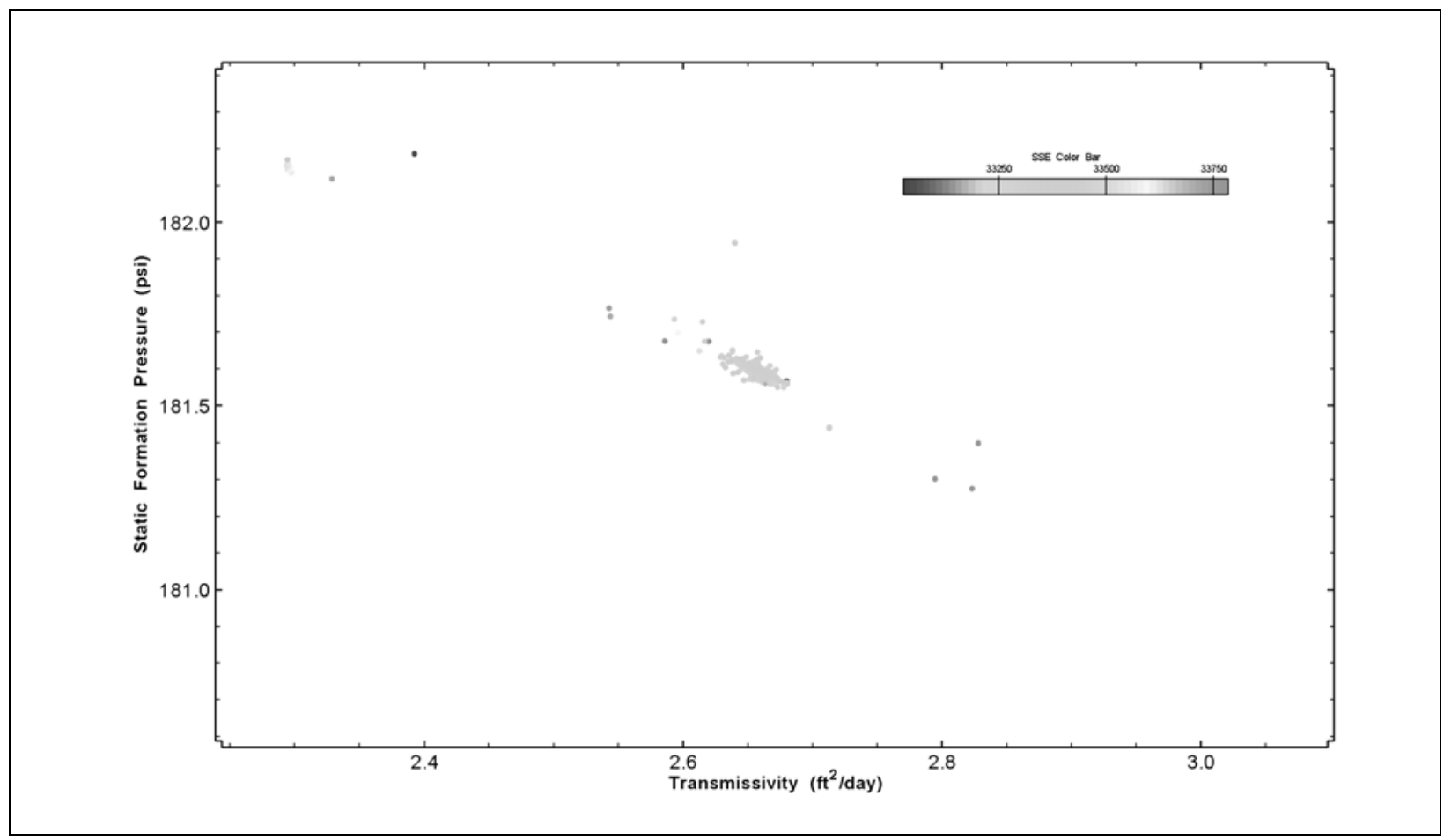

Figure 3-6

Static Pressure Versus Transmissivity Color Mapped to SSE for the FY 2006 Test 


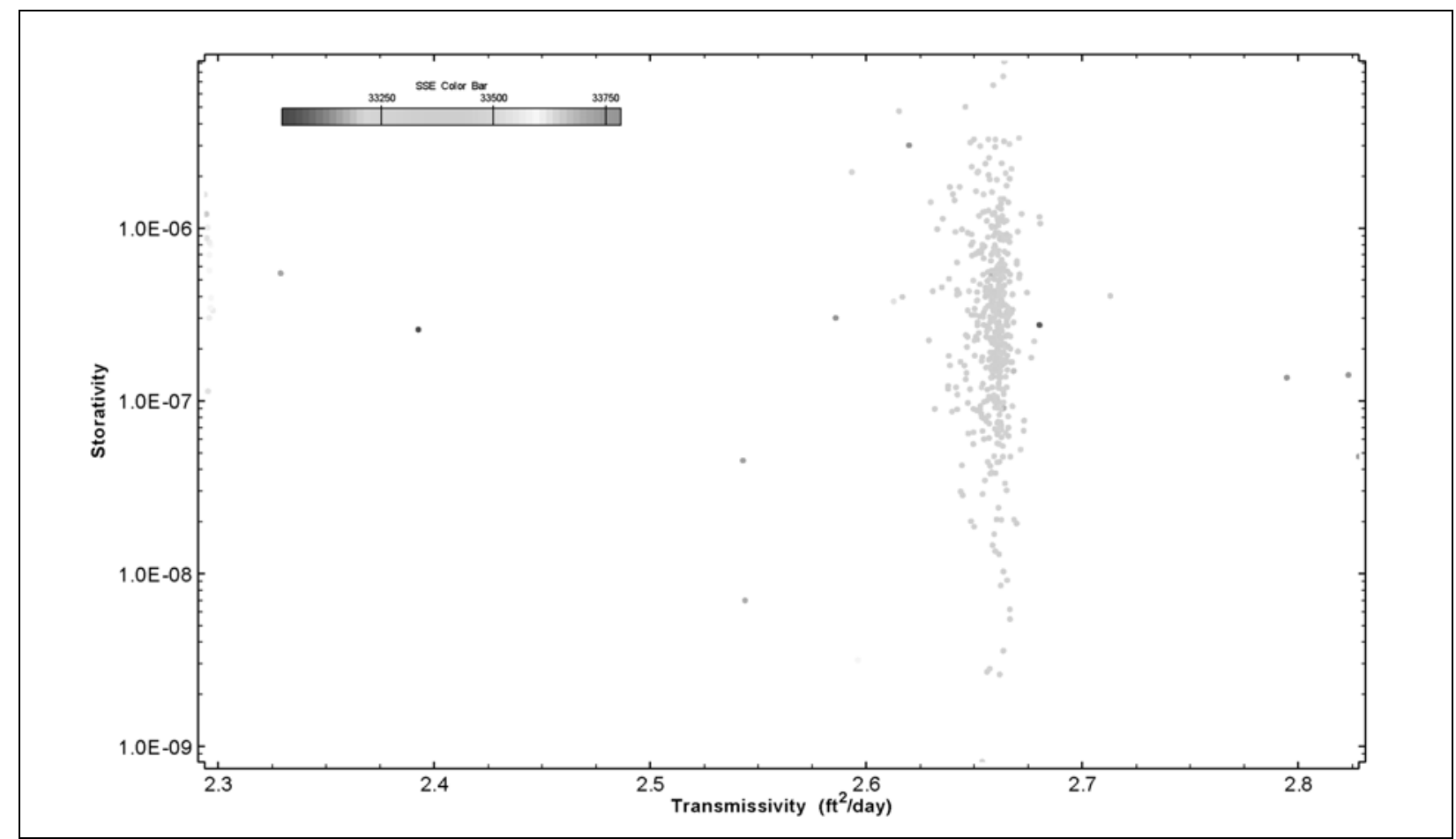

Figure 3-7

Storativity Versus Transmissivity Color Mapped to SSE for the FY 2006 Test

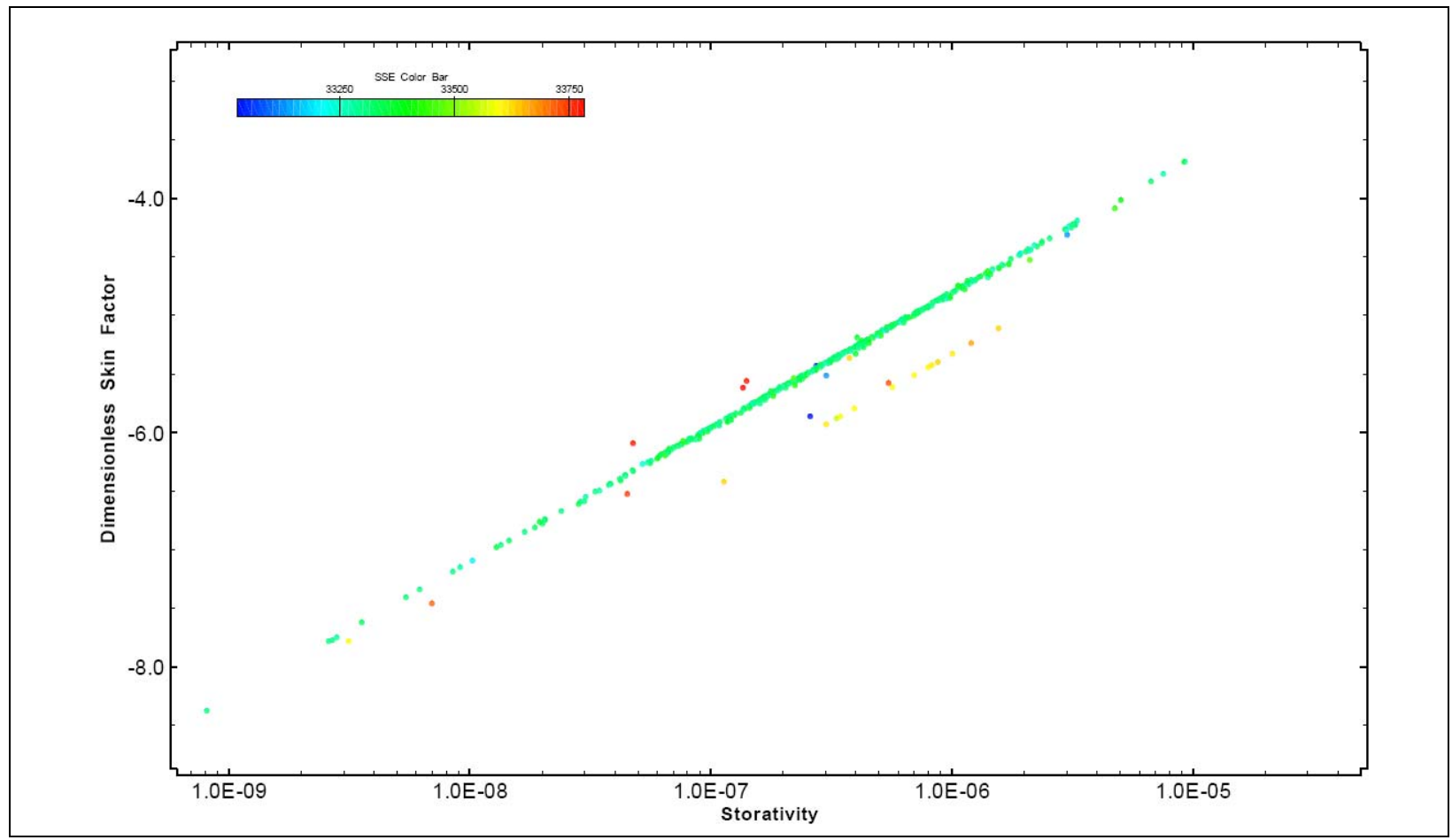

Figure 3-8

Skin Factor Versus Storativity Color Mapped to SSE for the FY 2006 Test 


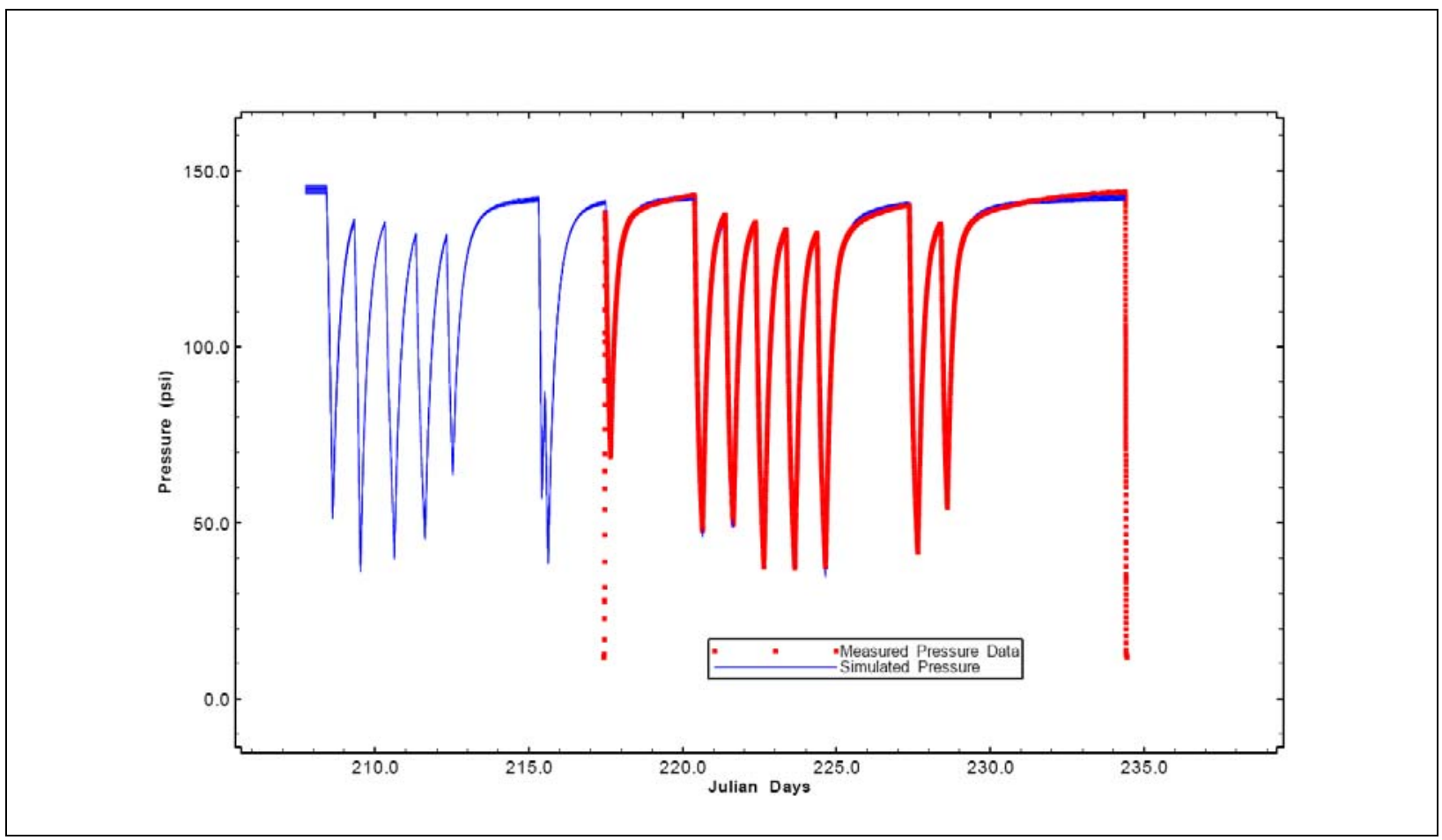

Figure 3-9

Cartesian Horsetail Plot for the FY 2005 Test

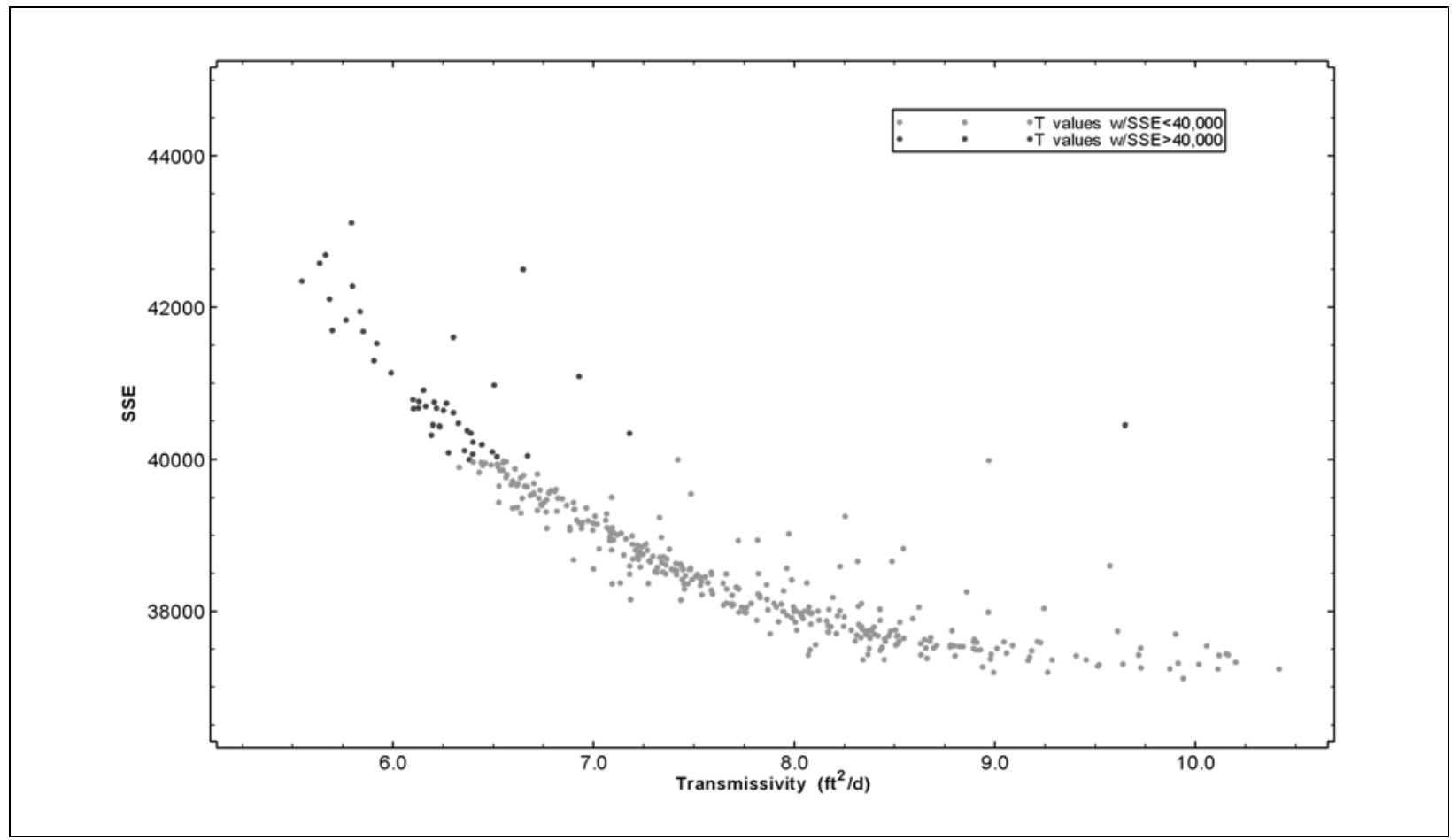

Figure 3-10

Plot of SSE Versus Transmissivity for the FY 2005 Test 


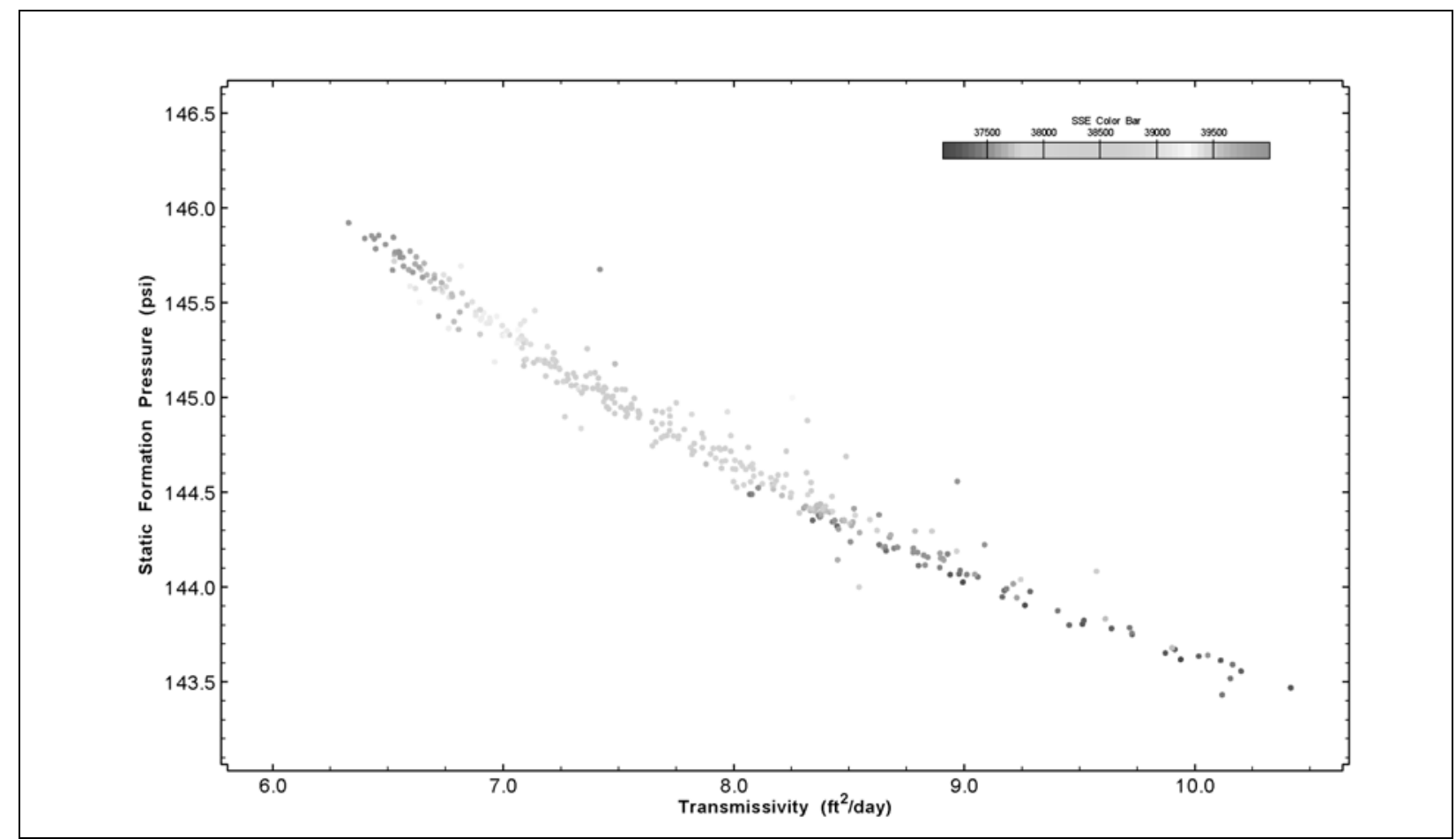

Figure 3-11

Static Pressure Versus Transmissivity Color Mapped to SSE for the FY 2005 Test

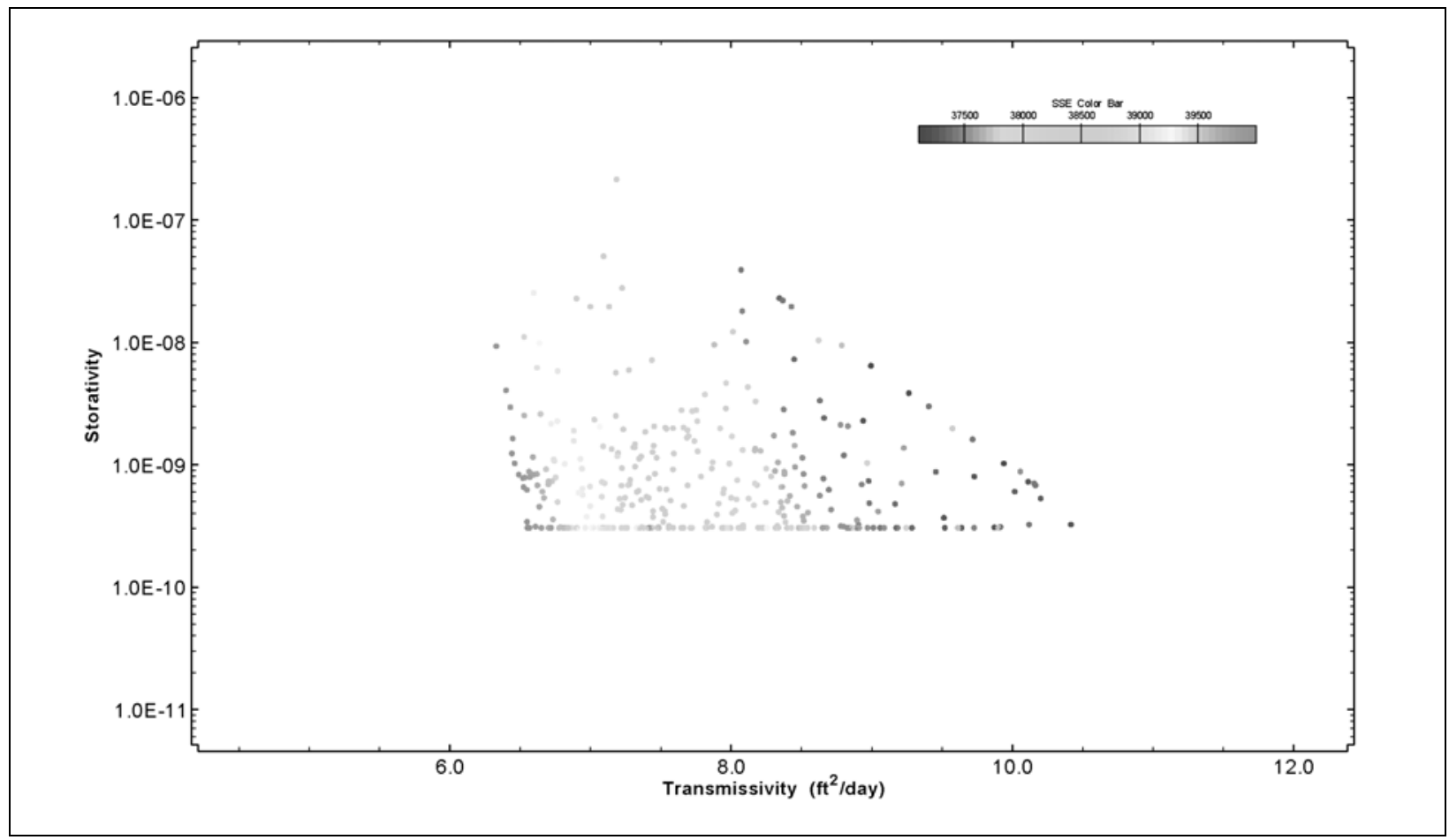

Figure 3-12

Storativity Versus Transmissivity Color Mapped to SSE for the FY 2005 Test 


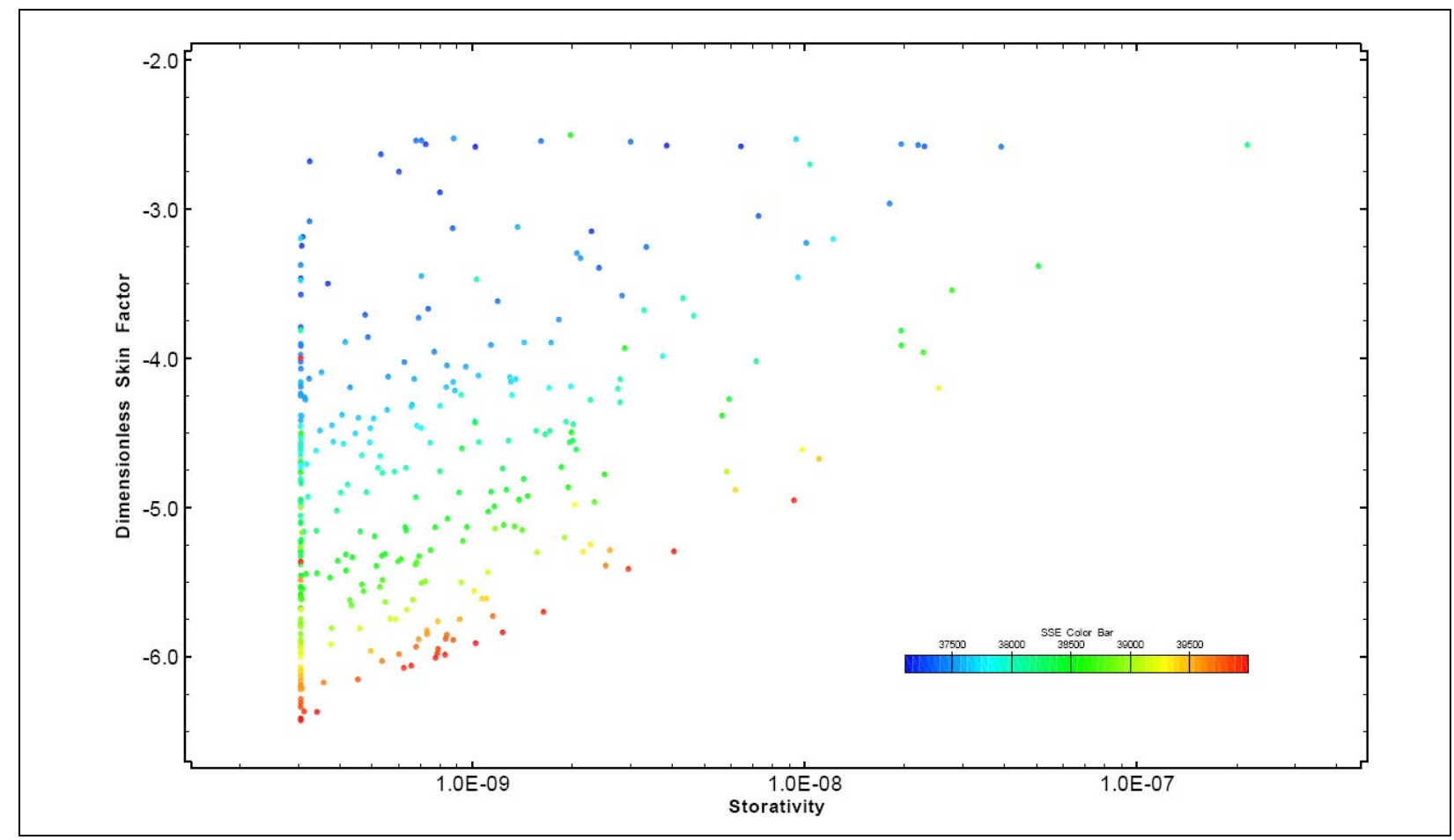

Figure 3-13

Skin Factor Versus Storativity Color Mapped to SSE for the FY 2005 Test

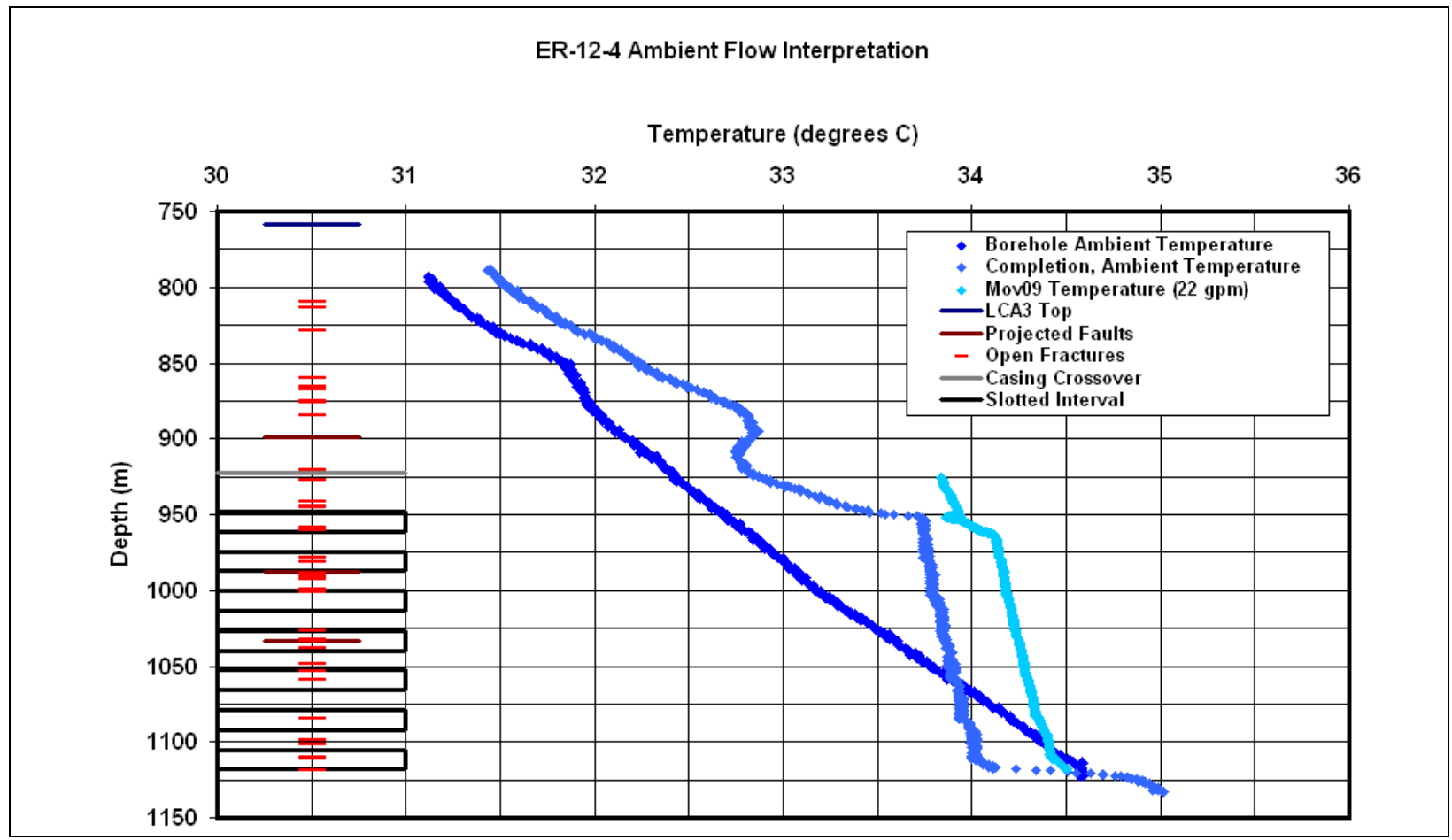

Figure 3-14

Temperature Profile During Pumping 


\subsection{Groundwater Chemistry}

This section presents an evaluation of the analytical results of the groundwater characterization samples collected during the well development and hydraulic testing activities at ER-12-4. Both depth-discrete bailed samples and well composite samples from the pumping discharge were collected at this site. The purpose of a discrete bailer is to collect groundwater samples that represent the groundwater quality of a depth-specific subsection of the formation supplying water to the well. The discrete samples are collected at a specific depth under pumping conditions and, therefore, represent groundwater produced at or below that depth. The composite groundwater sample is generally considered to be representative of all water-producing zones that contribute to the well. The groundwater chemistry data are used to determine whether ER-12-4 was sufficiently developed to restore the natural groundwater quality to that of the formation around the well. The data obtained from the depth-discrete and composite samples are compared to determine whether differences in water quality exist between the depth-specific zone and the combination of producing zones represented by the composite sample. The groundwater chemistry data are then evaluated to determine relative similarities between these groundwaters, groundwaters sampled from other wells in the area, and other wells that sample the same HSU. Inter-laboratory (DRI, LANL, LLNL, and USGS) comparisons for the composite samples are also described.

Composite groundwater samples were also collected in early 2006 after additional purging of the well. The available chemistry data for these samples are compared to that observed for the earlier samples. In addition, new oxidation/reduction potential measurements were made by LANL during this sampling event. The results of these measurements are also presented within this section.

\subsection{ER-12-4 Groundwater Characterization Sample Results}

On August 4, 2005, unfiltered (124-080405-2) and filtered (124-080405-2F) depth-discrete bailed samples were obtained from a depth of 3,385 ft bgs while the pump was operating at a pumping rate between 3 and $9 \mathrm{gpm}$. At the time of sample collection, approximately 25,000 gallons (gal) of 
groundwater (approximately 3.5 wellbore volumes) had been pumped from the well. The wellbore volume of ER-12-4 is approximately 7,000 gal. The sample was obtained using a DRI wireline logging truck, a boom truck, and a remotely controlled discrete bailer.

On August 15, 2005, composite groundwater characterization samples (124-081505-1 and -1F), as well as field duplicate quality control samples (124-081505-2 and -2F), were collected from the wellhead sampling port after more than 50,000 gal of groundwater had been pumped from the well during development and testing activities. The production rate at the time of sampling was 9 gpm.

On April 25, 2006, composite groundwater characterization samples (124-042506-1 and -1F), as well as field duplicate quality control samples (124-042506-2 and -2F), were collected from the wellhead sampling port. Samples were collected after purging an additional 22,800 gal of groundwater from the well using a low-volume electric submersible pump. The production rate at the time of sampling was approximately 4.4 gpm.

The analytical results for these samples are presented in Table 4-1. Note that the analysis results for filtered (samples with an "F" extension for the sample identification number) and unfiltered samples (no "F" extension) are listed as the dissolved and total concentrations, respectively. In addition, samples were collected for analysis by LLNL, the USGS, DRI, and LANL; the analytical results associated with these samples are presented in Table 4-2. Analysis results are available from the USGS and LANL for the April 2006 samples (identified with an asterisk in Table 4-2); analysis results from DRI and LLNL are pending for this more recent sampling of ER-12-4.

\subsubsection{Major, Minor, and Trace Constituents and Physical Parameters}

The data in Table 4-1 indicate that the wellhead composite groundwater characterization samples have similar analytical results when compared to each other and when compared to the depth-discrete samples. In general, good agreement between laboratories is also observed (Table 4-2). Bicarbonate ([HCO $\left.\mathrm{HC}_{3}\right] 66.5$ to 102 milligrams per liter $[\mathrm{mg} / \mathrm{L}]$ as calcium carbonate $\left[\mathrm{CaCO}_{3}\right]$ and $86 \mathrm{mg} / \mathrm{L}$ as $\mathrm{HCO}_{3}$ ) is the predominant anion, and sodium (25 to $31.5 \mathrm{mg} / \mathrm{L}$ ) is the predominant cation. Note that a superior charge balance is observed for the DRI sample (2.9 vs. 10.5) when the laboratory value reported for $\mathrm{HCO}_{3}(86 \mathrm{mg} / \mathrm{L})$ is used rather than the field value $\left(102 \mathrm{mg} / \mathrm{L}\right.$ as $\left.\mathrm{CaCO}_{3}\right)$. Therefore, the laboratory value is used for further evaluations. 
Table 4-1

Analytical Results for Groundwater Characterization Samples at ER-12-4

(Page 1 of 3)

\begin{tabular}{|c|c|c|c|c|c|c|c|c|c|c|c|c|}
\hline \multirow[t]{3}{*}{ Analyte } & \multirow[t]{3}{*}{$\begin{array}{l}\text { Reporting } \\
\text { Limit }^{\mathrm{a}}\end{array}$} & \multirow[t]{3}{*}{ Laboratory } & \multicolumn{2}{|c|}{$\begin{array}{c}\text { Depth-Discrete } \\
\text { Sample } \\
\text { from } 3,385 \mathrm{ft} \text { bgs } \\
124-080405-2 \\
124-080405-2 \mathrm{~F}\end{array}$} & \multicolumn{2}{|c|}{$\begin{array}{c}\text { Wellhead Composite } \\
\text { Sample } \\
124-081505-1 \\
124-081505-1 \mathrm{~F}\end{array}$} & \multicolumn{2}{|c|}{$\begin{array}{c}\text { Duplicate Wellhead } \\
\text { Composite Sample } \\
124-081505-2 \\
124-081505-2 F\end{array}$} & \multicolumn{2}{|c|}{$\begin{array}{c}\text { Wellhead Composite } \\
\text { Sample } \\
124-042506-1 \\
124-042506-1 \mathrm{~F}\end{array}$} & \multicolumn{2}{|c|}{$\begin{array}{c}\text { Duplicate Wellhead } \\
\text { Composite Sample } \\
124-042506-2 \\
124-042506-2 F\end{array}$} \\
\hline & & & \multicolumn{4}{|c|}{ Metals (mg/L) } & & & & & & \\
\hline & & & Total & Dissolved & Total & Dissolved & Total & Dissolved & Total & Dissolved & Total & Dissolved \\
\hline Aluminum & 0.2 & EMAX/PAI & 0.27 & $<0.2$ & $<0.2$ & $<0.2$ & $<0.2$ & $<0.2$ & 0.21 & $<0.2$ & $<0.2$ & $<0.2$ \\
\hline Arsenic & 0.01 & EMAX/PAI & $<0.01$ & $<0.01$ & $<0.01$ & $<0.01$ & $<0.01$ & $<0.01$ & $<0.01$ & $<0.01$ & $0.0023 \mathrm{~J}-$ & $0.0035 \mathrm{~J}$ \\
\hline Barium & 0.1 & EMAX/PAI & $0.015 \mathrm{~J}$ & $0.014 \mathrm{~J}$ & $0.011 \mathrm{~J}$ & $0.009 \mathrm{~J}$ & $0.013 \mathrm{~J}$ & $0.009 \mathrm{~J}$ & $0.022 \mathrm{~J}$ & $0.02 \mathrm{~J}$ & $0.02 \mathrm{~J}$ & $0.02 \mathrm{~J}$ \\
\hline Cadmium & 0.005 & EMAX/PAI & $<0.005$ & $<0.005$ & $<0.005$ & $<0.005$ & $<0.005$ & $<0.005$ & $<0.005$ & $<0.005$ & $<0.005$ & $<0.005$ \\
\hline Calcium & 1 & EMAX/PAI & 11.4 & 10.6 & 9.28 & 8.29 & 10.6 & 8.47 & 11 & 8.3 & 9.3 & 8.6 \\
\hline Chromium & 0.01 & EMAX/PAI & $0.0029 \mathrm{~J}$ & $<0.01$ & $0.0027 \mathrm{~J}$ & $<0.01$ & $0.0043 \mathrm{~J}$ & $<0.01$ & $<0.01$ & $<0.01$ & $<0.01$ & $<0.01$ \\
\hline Iron & 0.1 & EMAX/PAI & 1.03 & 0.35 & 1.61 & $<0.1$ & 2.51 & $<0.1$ & 0.64 & $<0.1$ & 0.31 & 0.03 \\
\hline Lead & 0.003 & EMAX/PAI & $<0.003$ & $<0.003$ & $<0.003$ & $<0.003$ & $<0.003$ & $<0.003$ & $<0.003$ & $<0.003$ & $<0.003$ & $<0.003$ \\
\hline Lithium & 0.01 & EMAX/PAI & $0.018 \mathrm{~J}+$ & $0.020 \mathrm{~J}+$ & $0.013 \mathrm{~J}+$ & $0.013 \mathrm{~J}+$ & $0.015 \mathrm{~J}+$ & $0.012 \mathrm{~J}+$ & 0.024 & 0.017 & 0.018 & 0.016 \\
\hline Magnesium & 1 & EMAX/PAI & 3.49 & 3.72 & 3.26 & 2.99 & 3.85 & 3.06 & 4.7 & 3.1 & 3.6 & 3.2 \\
\hline Manganese & 0.01 & EMAX/PAI & 0.024 & 0.012 & 0.06 & 0.038 & 0.077 & 0.039 & 0.03 & 0.016 & 0.023 & 0.016 \\
\hline Mercury & 0.0002 & EMAX/PAI & $<0.0002$ & $<0.0002$ & $<0.0002$ & $<0.0002$ & $<0.0002$ & $<0.0002$ & $<0.0002$ & $<0.0002$ & $<0.0002$ & $<0.0002$ \\
\hline Potassium & 1 & EMAX/PAI & 3.87 & 4.52 & 3.09 & 3.06 & 3.68 & 3.02 & 4.0 & 3.9 & 4.0 & 4.0 \\
\hline Selenium & 0.005 & EMAX/PAI & $<0.005$ & $<0.005$ & $<0.005$ & $<0.005$ & $<0.005$ & $<0.005$ & $<0.005$ & $<0.005$ & $<0.005$ & $<0.005$ \\
\hline Silicon & 0.05 & EMAX/PAI & 7.0 & 6.9 & 4.8 & 4.2 & 5.0 & 4.4 & 7.8 & 7.0 & 7.3 & 7.0 \\
\hline Silver & 0.01 & EMAX/PAI & $<0.01$ & $<0.01$ & $<0.01$ & $<0.01$ & $<0.01$ & $<0.01$ & $<0.01$ & $<0.01$ & $<0.01$ & $<0.01$ \\
\hline Sodium & 1 & EMAX/PAI & 27.8 & 31.5 & 25.8 & 25.6 & 29.8 & 25.3 & 25 & 25 & 25 & 25 \\
\hline Strontium & 0.01 & EMAX/PAI & 0.074 & 0.083 & 0.062 & 0.056 & 0.072 & 0.058 & 0.051 & 0.050 & 0.050 & 0.050 \\
\hline Uranium & $0.1,0.0001$ & EMAX/PAI & $<0.1$ & $<0.1$ & $<0.1$ & $<0.1$ & $<0.1$ & $<0.1$ & 0.0004 & 0.0004 & 0.0003 & 0.0003 \\
\hline
\end{tabular}


Table 4-1

Analytical Results for Groundwater Characterization Samples at ER-12-4

(Page 2 of 3)

\begin{tabular}{|c|c|c|c|c|c|c|c|c|c|c|c|c|}
\hline Analyte & $\begin{array}{l}\text { Reporting } \\
\text { Limit }^{\mathrm{a}}\end{array}$ & Laboratory & \multicolumn{2}{|c|}{$\begin{array}{c}\text { Depth-Discrete } \\
\text { Sample } \\
\text { from } 3,385 \mathrm{ft} \text { bgs } \\
124-080405-2 \\
124-080405-2 F\end{array}$} & \multicolumn{2}{|c|}{$\begin{array}{c}\text { Wellhead Composite } \\
\text { Sample } \\
124-081505-1 \\
124-081505-1 \mathrm{~F}\end{array}$} & \multicolumn{2}{|c|}{$\begin{array}{c}\text { Duplicate Wellhead } \\
\text { Composite Sample } \\
124-081505-2 \\
124-081505-2 F\end{array}$} & \multicolumn{2}{|c|}{$\begin{array}{c}\text { Wellhead Composite } \\
\text { Sample } \\
124-042506-1 \\
124-042506-1 \mathrm{~F}\end{array}$} & \multicolumn{2}{|c|}{$\begin{array}{c}\text { Duplicate Wellhead } \\
\text { Composite Sample } \\
124-042506-2 \\
124-042506-2 F\end{array}$} \\
\hline \multicolumn{13}{|c|}{ Inorganics (mg/L) } \\
\hline & & & Total & Dissolved & Total & Dissolved & Total & Dissolved & Total & Dissolved & Total & Dissolved \\
\hline Alkalinity, $\mathrm{CO}_{3}$ as $\mathrm{CaCO}_{3}$ & $5,5,10$ & EMAX/PAI & $<5$ & NM & $<5$ & NM & $<5$ & NM & $<10$ & NM & $<10$ & NM \\
\hline Alkalinity, $\mathrm{HCO}_{3}$ as $\mathrm{CaCO}_{3}$ & $5,5,10$ & EMAX/PAI & 66.5 & NM & 70.7 & NM & 73.4 & NM & 76 & NM & 76 & NM \\
\hline Bromide & $0.5,0.5,1,0.2,0.2$ & EMAX/PAI & NM & $<0.5$ & NM & $0.46 \mathrm{~J}$ & NM & $<1$ & NM & $<0.2$ & NM & $<0.2$ \\
\hline Chloride & $0.25,0.25,0.5,0.2,0.2$ & EMAX/PAI & NM & 8.73 & NM & 9.14 & NM & 9.15 & NM & 9.0 & NM & 8.9 \\
\hline Fluoride & $0.25,0.25,0.5,0.1,0.1$ & EMAX/PAI & NM & 0.72 & NM & 0.69 & NM & 0.84 & NM & 0.77 & NM & 0.79 \\
\hline $\mathrm{pH}$ & 0.1 & EMAX/PAI & 8.21 & NM & 8.67 & NM & 8.67 & NM & $8.63 \mathrm{~J}$ & NM & $5.80 \mathrm{~J}$ & NM \\
\hline Specific Conductivity $(\mu \mathrm{S} / \mathrm{cm})$ & 1 & EMAX/PAI & 211 & NM & 205 & NM & 206 & NM & 208 & NM & 204 & NM \\
\hline Sulfate & $1,2,1$ & EMAX/PAI & NM & 11.6 & NM & 11 & NM & 10.7 & NM & 12 & NM & 12 \\
\hline Total Alkalinity as $\mathrm{CaCO}_{3}$ & $5,5,10$ & EMAX/PAI & 66.5 & NM & 70.7 & NM & 73.4 & NM & 76 & NM & 76 & NM \\
\hline Total Dissolved Solids & $10,10,20$ & EMAX/PAI & 150 & NM & 150 & NM & 145 & NM & 140 & NM & 130 & NM \\
\hline \multicolumn{13}{|c|}{ Organics (mg/L) } \\
\hline Total Organic Carbon & 1 & EMAX/PAI & 1.8 & NM & 1.12 & NM & 0.76 & NM & $<1$ & NM & $<1$ & NM \\
\hline \multicolumn{13}{|c|}{ Redox Parameter (mg/L) } \\
\hline Total Sulfide & $1,1,2$ & EMAX/PAI & $<1$ & NM & $<1$ & NM & $<1$ & NM & $<2$ & NM & $<2$ & NM \\
\hline \multicolumn{13}{|c|}{ Radiological Indicator Parameters-Level I (pCi/L) } \\
\hline & & & Result & Error & Result & Error & Result & Error & Result & Error & Result & Error \\
\hline Tritium & $360,360,360,350,310$ & PAI & $<360$ & N/A & $<360$ & N/A & $<360$ & N/A & $<350$ & N/A & $<310$ & N/A \\
\hline Gamma Spectroscopy & Varies by Nuclide & PAl & ND & $\mathrm{N} / \mathrm{A}$ & ND & N/A & ND & $\mathrm{N} / \mathrm{A}$ & ND & $\mathrm{N} / \mathrm{A}$ & ND & N/A \\
\hline
\end{tabular}


Table 4-1

Analytical Results for Groundwater Characterization Samples at ER-12-4

(Page 3 of 3)

\begin{tabular}{|c|c|c|c|c|c|c|c|c|c|c|c|c|}
\hline Analyte & $\begin{array}{l}\text { Reporting } \\
\text { Limit }^{\mathrm{a}}\end{array}$ & Laboratory & \multicolumn{2}{|c|}{$\begin{array}{c}\text { Depth-Discrete } \\
\text { Sample } \\
\text { from } 3,385 \mathrm{ft} \text { bgs } \\
124-080405-2 \\
124-080405-2 \mathrm{~F}\end{array}$} & \multicolumn{2}{|c|}{$\begin{array}{c}\text { Wellhead Composite } \\
\text { Sample } \\
\text { 124-081505-1 } \\
124-081505-1 F\end{array}$} & \multicolumn{2}{|c|}{$\begin{array}{c}\text { Duplicate Wellhead } \\
\text { Composite Sample } \\
124-081505-2 \\
124-081505-2 F\end{array}$} & \multicolumn{2}{|c|}{$\begin{array}{c}\text { Wellhead Composite } \\
\text { Sample } \\
124-042506-1 \\
124-042506-1 \mathrm{~F}\end{array}$} & \multicolumn{2}{|c|}{$\begin{array}{c}\text { Duplicate Wellhead } \\
\text { Composite Sample } \\
124-042506-2 \\
124-042506-2 F\end{array}$} \\
\hline \multicolumn{13}{|c|}{ Radiological Indicator Parameters-Level II (pCi/L) } \\
\hline & & & Result & Error & Result & Error & Result & Error & Result & Error & Result & Error \\
\hline Gross Alpha & $0.92,1.32,1.57,0.53,0.6$ & PAl & $<0.92$ & N/A & $<1.32$ & $\mathrm{~N} / \mathrm{A}$ & $<1.57$ & N/A & $0.58^{c}$ & 0.35 & $<0.6$ & N/A \\
\hline Gross Beta & $2,3,2.9,1.1,1.1$ & PAl & $2.3^{\mathrm{c}}$ & 1.3 & $3.9^{\mathrm{c}}$ & 1.7 & $3.4^{\mathrm{c}}$ & 1.6 & 4.6 & 1 & 3.9 & 0.94 \\
\hline Carbon-14 & $430,430,480$ & PAl & $<430$ & $N / A$ & $<430$ & $\mathrm{~N} / \mathrm{A}$ & $<430$ & $\mathrm{~N} / \mathrm{A}$ & $<480$ & $\mathrm{~N} / \mathrm{A}$ & $<480$ & $N / A$ \\
\hline Iodine-129 & $2.6,2.5,3.5,3.2$ & PAI & NM & $N / A$ & $<2.6$ & $\mathrm{~N} / \mathrm{A}$ & $<2.5$ & $\mathrm{~N} / \mathrm{A}$ & $<3.5$ & $\mathrm{~N} / \mathrm{A}$ & $<3.2$ & N/A \\
\hline Plutonium-238 & $\begin{array}{c}0.014,0.035,0.026 \\
0.021,0.028\end{array}$ & PAI & $<0.014$ & $\mathrm{~N} / \mathrm{A}$ & $<0.035$ & $\mathrm{~N} / \mathrm{A}$ & $<0.026$ & $\mathrm{~N} / \mathrm{A}$ & $<0.021$ & $\mathrm{~N} / \mathrm{A}$ & $<0.028$ & N/A \\
\hline Plutonium-239 & $\begin{array}{c}0.022,0.014,0.013 \\
0.026,0.01\end{array}$ & PAI & $<0.034$ & $\mathrm{~N} / \mathrm{A}$ & $<0.014$ & $\mathrm{~N} / \mathrm{A}$ & $0.014^{c}$ & 0.018 & $<0.026$ & $\mathrm{~N} / \mathrm{A}$ & $<0.010$ & N/A \\
\hline Strontium-90 & $0.58,0.59,0.53,0.58$ & PAI & NM & $N / A$ & $<0.58$ & $\mathrm{~N} / \mathrm{A}$ & $<0.59$ & $\mathrm{~N} / \mathrm{A}$ & $<0.53$ & $\mathrm{~N} / \mathrm{A}$ & $<0.58$ & N/A \\
\hline Technetium-99 & $5.9,6,6.3$ & PAI & NM & $\mathrm{N} / \mathrm{A}$ & $<5.9$ & $\mathrm{~N} / \mathrm{A}$ & $<6$ & N/A & $<6.3$ & $\mathrm{~N} / \mathrm{A}$ & $<6.3$ & N/A \\
\hline Uranium-235 & $30,27,36,37,36$ & PAI & $<30$ & N/A & $<27$ & $\mathrm{~N} / \mathrm{A}$ & $<55$ & N/A & $<37$ & $\mathrm{~N} / \mathrm{A}$ & $<36$ & N/A \\
\hline
\end{tabular}

${ }^{a}$ Where five reporting limits are given, the reporting sequence is 1) $\left.\left.\left.\left.124-080405-2,-2 F, 2\right) 124-081505-1,-1 F, 3\right) 124-081505-2,-2 F, 4\right) ~ 124-042506-1,-1 F, 5\right) 124-042506-2,-2 F$.

Where four reporting limits are given, the reporting sequence is 1) 124-081505-1, -1F, 2) 124-081505-2, -2F, 3) 124-042506-1, -1F, 4) 124-042506-2, -2F.

Where three reporting limits are given, the reporting sequence is 1) $124-080405-2,-2 F, 2) 124-081505-1,-1 F,-2,-2 F, 3) 124-042506-1,-1 F,-2,-2 F$.

"Those values that are above the method detection limit but less than the reporting limit are given a "J" qualifier.

${ }^{c}$ Reported value is less than the detection limit plus analytical error; the presence of this parameter is unlikely.

$\mathrm{CO}_{3}=$ Carbonate

$\mathrm{CaCO}_{3}=$ Calcium carbonate

$\mathrm{HCO}_{3}=$ Bicarbonate

EMAX = EMAX Laboratories, Inc

$\mathrm{J}=$ Indicates an estimated value

$\mathrm{J}+=$ Indicates an estimated value, biased high

$\mathrm{J}$ - = Indicates an estimated value, biased low
N/A = Not applicable

$\mathrm{ND}=$ No gamma spectroscopy nuclides detected above detection limit

$\mathrm{NM}=$ Not measured

$\mathrm{PAI}=$ Paragon Analytics, Inc

$\mathrm{pCi} / \mathrm{L}=$ Picocuries per liter

$\mathrm{SU}=$ Standard unit

$\mu \mathrm{S} / \mathrm{cm}=$ MicroSiemens per centimeter 
Table 4-2

Additional Analyses Results for ER-12-4 Wellhead Composite Samples (Page 1 of 3 )

\begin{tabular}{|c|c|c|c|}
\hline Analyte* & $\begin{array}{c}\text { Laboratory } \\
\text { Detection Limit }\end{array}$ & Laboratory & $\begin{array}{l}\text { Results of Wellhead Composite } \\
\text { (Sample date - 8/15-16/05, 4/25/06*) }\end{array}$ \\
\hline \multicolumn{4}{|c|}{ Water Chemistry } \\
\hline Alkalinity, $\mathrm{CO}_{3}$ as $\mathrm{CaCO}_{3}$, Field $(\mathrm{mg} / \mathrm{L})$ & Not Provided & $\overline{\mathrm{DRI}}$ & 0.8 \\
\hline Alkalinity, $\mathrm{HCO}_{3}$ as $\mathrm{CaCO}_{3}$, Field $(\mathrm{mg} / \mathrm{L})$ & Not Provided & DRI & 102 \\
\hline Alkalinity, Total as $\mathrm{CaCO}_{3}$, Field (mg/L) & Not Provided & DRI & 102.8 \\
\hline Aluminum (ppb) & Not Provided & DRI & 1.69 \\
\hline${ }^{*}$ Ammonia $(\mathrm{mg} / \mathrm{L})$ & Not Provided & LANL & ND \\
\hline Antimony $(\mu \mathrm{g} / \mathrm{L})$ & 1 & USGS & $<1 \mid<1$ \\
\hline *Antimony $(\mu \mathrm{g} / \mathrm{L})$ & 1 & USGS & $<1 \mid<1$ \\
\hline Arsenic $(\mu \mathrm{g} / \mathrm{L})$ & 3 & USGS & $<3 \mid<3$ \\
\hline${ }^{*}$ Arsenic $(\mu \mathrm{g} / \mathrm{L})$ & 3 & USGS & $<3 \mid<3$ \\
\hline Barium $(\mu \mathrm{g} / \mathrm{L})$ & 15 & USGS & $<15 \mid<15$ \\
\hline${ }^{*}$ Barium $(\mu \mathrm{g} / \mathrm{L})$ & 15 & USGS & $22 \mid 23$ \\
\hline *Beryllium $(\mu \mathrm{g} / \mathrm{L})$ & 1 & USGS & $<1 \mid<1$ \\
\hline Bicarbonate (mg/L) & 1 & DRI & 86 \\
\hline Boron $(\mu \mathrm{g} / \mathrm{L})$ & 50 & USGS & $<50 \mid<50$ \\
\hline *Boron $(\mu \mathrm{g} / \mathrm{L})$ & 50 & USGS & $55 \mid 58$ \\
\hline Bromide (mg/L) & Not Provided & DRI & 0.09 \\
\hline Cadmium ( $\mu \mathrm{g} / \mathrm{L})$ & 1 & USGS & $<1 \mid<1$ \\
\hline${ }^{*}{ }^{*}$ admium $(\mu \mathrm{g} / \mathrm{L})$ & 1 & USGS & $<1 \mid<1$ \\
\hline Calcium (mg/L) & 0.2 & DRI & 10.6 \\
\hline Calcium (mg/L) & Not Provided & LLNL & 8.4 \\
\hline Carbonate (mg/L) & 1 & DRI & 1.4 \\
\hline Chloride (mg/L & 0.02 & DRI & 9.5 \\
\hline Chloride (mg/L) & Not Provided & LLNL & 9.1 \\
\hline Chromium ( $\mu \mathrm{g} / \mathrm{L})$ & 4.5 & USGS & $<4.5 \mid<4.5$ \\
\hline${ }^{*}$ Chromium $(\mu \mathrm{g} / \mathrm{L})$ & 4.5 & USGS & $<4.5 \mid<4.5$ \\
\hline Cobalt $(\mu \mathrm{g} / \mathrm{L})$ & 1.3 & USGS & $<1.3 \mid<1.3$ \\
\hline${ }^{*}$ Cobalt $(\mu \mathrm{g} / \mathrm{L})$ & 1.3 & USGS & $<1.3 \mid<1.3$ \\
\hline Copper $(\mu \mathrm{g} / \mathrm{L})$ & 2.5 & USGS & $<2.5 \mid<2.5$ \\
\hline${ }^{*}$ Copper $(\mu \mathrm{g} / \mathrm{L})$ & 2.5 & USGS & $<2.5 \mid<2.5$ \\
\hline Dissolved Inorganic Carbon as $\mathrm{HCO}_{3}(\mathrm{mg} / \mathrm{L})$ & Not Provided & LLNL & 84 \\
\hline${ }^{*}$ Dissolved Oxygen $(\mathrm{mg} / \mathrm{L})$ & Not Provided & LANL & 2.9 \\
\hline${ }^{*}$ Eh (mV vs. SHE) & Not Provided & LANL & 332 \\
\hline Fluoride (mg/L) & 0.1 & DRI & 0.68 \\
\hline Fluoride (mg/L) & Not Provided & LLNL & 0.3 \\
\hline Iron $(\mathrm{ppb})$ & Not Provided & DRI & 53.9 \\
\hline *Iron $(\mu \mathrm{g} / \mathrm{L})$ & Not Provided & LANL & 40 \\
\hline *Iron (II) $(\mu \mathrm{g} / \mathrm{L})$ & Not Provided & LANL & ND \\
\hline Lead $(\mu \mathrm{g} / \mathrm{L})$ & 0.9 & USGS & $<0.9 \mid<0.9$ \\
\hline *Lead $(\mu \mathrm{g} / \mathrm{L})$ & 0.9 & USGS & $<0.9 \mid<0.9$ \\
\hline Lithium $(\mu \mathrm{g} / \mathrm{L})$ & 2.5 & USGS & \begin{tabular}{l|l}
13 & 13
\end{tabular} \\
\hline *Lithium $(\mu \mathrm{g} / \mathrm{L})$ & 2.5 & USGS & $15 \mid 16$ \\
\hline Magnesium (mg/L) & 0.1 & DRI & 3.44 \\
\hline Magnesium (mg/L) & Not Provided & LLNL & 3.5 \\
\hline Manganese $(\mu \mathrm{g} / \mathrm{L})$ & 0.75 & USGS & \begin{tabular}{l|l|}
38 & 38 \\
\end{tabular} \\
\hline *Manganese $(\mu \mathrm{g} / \mathrm{L})$ & 0.75 & USGS & \begin{tabular}{l|l|}
13 & 13 \\
\end{tabular} \\
\hline${ }^{*}$ Manganese $(\mu \mathrm{g} / \mathrm{L})$ & Not Provided & LANL & 31 \\
\hline Molybdenum ( $\mu \mathrm{g} / \mathrm{L})$ & 0.5 & USGS & \begin{tabular}{l|l|}
18 & 18
\end{tabular} \\
\hline
\end{tabular}


Table 4-2

Additional Analyses Results for ER-12-4 Wellhead Composite Samples (Page 2 of 3 )

\begin{tabular}{|c|c|c|c|}
\hline Analyte* $^{*}$ & $\begin{array}{c}\text { Laboratory } \\
\text { Detection Limit }\end{array}$ & Laboratory & $\begin{array}{l}\text { Results of Wellhead Composite } \\
\text { (Sample date - 8/15-16/05, 4/25/06*) }\end{array}$ \\
\hline *Molybdenum $(\mu \mathrm{g} / \mathrm{L})$ & 0.5 & USGS & \begin{tabular}{|l|l|}
1.4 & 1.4 \\
\end{tabular} \\
\hline Nickel $(\mu \mathrm{g} / \mathrm{L})$ & 15 & USGS & $<15 \mid<15$ \\
\hline *Nickel $(\mu \mathrm{g} / \mathrm{L})$ & 15 & USGS & $27 \mid 27$ \\
\hline Nitrate (mg/L as N) & 0.04 & DRI & 0.85 \\
\hline Nitrate $(\mathrm{mg} / \mathrm{L})$ & Not Provided & LLNL & 8.5 \\
\hline *Nitrate $(\mathrm{mg} / \mathrm{L})$ & Not Provided & LANL & 3.9 \\
\hline *Nitrite $(\mathrm{mg} / \mathrm{L})$ & Not Provided & LANL & 0.029 \\
\hline $\mathrm{pH}$, Field (pH units) & 0.02 & DRI & 8.72 \\
\hline $\mathrm{pH}$, Field (pH units) & Not Provided & LLNL & 8.8 \\
\hline${ }^{*} \mathrm{pH}$, Field (pH units) & Not Provided & LANL & 8.61 \\
\hline${ }^{*} \mathrm{pH}$, Field at $25^{\circ} \mathrm{C}$ ( $\mathrm{pH}$ units) & Not Provided & LANL & 8.59 \\
\hline $\mathrm{pH}$, Laboratory (pH units) & 0.02 & DRI & 8.43 \\
\hline Potassium (mg/L) & 0.1 & $\mathrm{DRI}$ & 3.64 \\
\hline Potassium (mg/L) & Not Provided & LLNL & 3.1 \\
\hline Rubidium ( $\mu \mathrm{g} / \mathrm{L})$ & 0.5 & USGS & \begin{tabular}{l|l|l|}
10.3 & 10.2 \\
\end{tabular} \\
\hline${ }^{*}$ Rubidium $(\mu \mathrm{g} / \mathrm{L})$ & 0.5 & USGS & \begin{tabular}{ll|l}
9.8 & 9.6 \\
\end{tabular} \\
\hline Selenium $(\mu \mathrm{g} / \mathrm{L})$ & 5 & USGS & $<5 \mid<5$ \\
\hline *Selenium $(\mu \mathrm{g} / \mathrm{L})$ & 5 & USGS & $<5 \mid<5$ \\
\hline Silicon (mg/L) & 0.5 & USGS & $4.7 \mid 4.7$ \\
\hline *Silicon (mg/L) & 0.5 & USGS & $7.1 \mid 7.1$ \\
\hline Silicon Dioxide (mg/L) & 0.2 & DRI & 15.6 \\
\hline Silicon Dioxide (mg/L) & 1.1 & USGS & $10 \mid 10$ \\
\hline *Silicon Dioxide (mg/L) & 1.1 & USGS & \begin{tabular}{ll|l|}
15.2 & 15.2 \\
\end{tabular} \\
\hline Silver $(\mu \mathrm{g} / \mathrm{L})$ & 3.5 & USGS & $<3.5 \mid<3.5$ \\
\hline *Silver $(\mu \mathrm{g} / \mathrm{L})$ & 3.5 & USGS & $<3.5 \mid<3.5$ \\
\hline Sodium $(\mathrm{mg} / \mathrm{L})$ & 0.1 & DRI & 28.3 \\
\hline Sodium (mg/L) & Not Provided & LLNL & 28.3 \\
\hline Specific Conductivity, Field $(\mu \mathrm{S} / \mathrm{cm})$ & Not Provided & LLNL & 196 \\
\hline Specific Conductivity, Lab $(\mu \mathrm{S} / \mathrm{cm})$ & 1 & DRI & 209 \\
\hline *Specific Conductivity at $25^{\circ} \mathrm{C}$, Field $(\mu \mathrm{S} / \mathrm{cm})$ & Not Provided & LANL & 214 \\
\hline${ }^{\star}$ Specific Conductivity, Field $(\mu \mathrm{S} / \mathrm{cm})$ & Not Provided & LANL & 225 \\
\hline Strontium $(\mu \mathrm{g} / \mathrm{L})$ & Not Provided & LLNL & 58 \\
\hline Strontium $(\mu \mathrm{g} / \mathrm{L})$ & 5 & USGS & $53 \mid 55$ \\
\hline *Strontium $(\mu \mathrm{g} / \mathrm{L})$ & 5 & USGS & \begin{tabular}{l|l|l|}
53 & 53 \\
\end{tabular} \\
\hline Sulfate $(\mathrm{mg} / \mathrm{L})$ & 0.05 & $\mathrm{DRI}$ & 12.3 \\
\hline Sulfate $(\mathrm{mg} / \mathrm{L})$ & Not Provided & LLNL & 11.4 \\
\hline Thorium $(\mu \mathrm{g} / \mathrm{L})$ & 0.15 & USGS & $<0.15 \mid<0.15$ \\
\hline${ }^{*}$ Thorium $(\mu \mathrm{g} / \mathrm{L})$ & 0.15 & USGS & $<0.15 \mid<0.15$ \\
\hline Total Dissolved Solids (mg/L) & Not Provided & DRI & 120 \\
\hline Uranium $(\mu \mathrm{g} / \mathrm{L})$ & Not Provided & LLNL & 0.3 \\
\hline Uranium $(\mu \mathrm{g} / \mathrm{L})$ & Not Provided & USGS & 0.0977 \\
\hline *Uranium $(\mu \mathrm{g} / \mathrm{L})$ & Not Provided & USGS & $0.384 \mid 0.382$ \\
\hline Uranium $(\mu \mathrm{g} / \mathrm{L})$ & 0.15 & USGS & $<0.15 \mid<0.15$ \\
\hline *Uranium $(\mu \mathrm{g} / \mathrm{L})$ & 0.15 & USGS & $0.40 \mid 0.40$ \\
\hline Vanadium $(\mu \mathrm{g} / \mathrm{L})$ & 1 & USGS & $<1 \mid<1$ \\
\hline *Vanadium $(\mu \mathrm{g} / \mathrm{L})$ & 1 & USGS & \begin{tabular}{ll|l|}
2.5 & \\
\end{tabular} \\
\hline Water Temperature $\left({ }^{\circ} \mathrm{C}\right)$ & Not Provided & LLNL & 23.9 \\
\hline *Water Temperature $\left({ }^{\circ} \mathrm{C}\right)$ & Not Provided & LANL & 29.8 \\
\hline
\end{tabular}


Table 4-2

Additional Analyses Results for ER-12-4 Wellhead Composite Samples (Page 3 of 3 )

\begin{tabular}{|c|c|c|c|}
\hline Analyte* & $\begin{array}{c}\text { Laboratory } \\
\text { Detection Limit }\end{array}$ & Laboratory & $\begin{array}{l}\text { Results of Wellhead Composite } \\
\text { (Sample date - 8/15-16/05, 4/25/06*) }\end{array}$ \\
\hline \multicolumn{4}{|c|}{ Environmental Isotopes } \\
\hline Argon-40 (atoms/g) & Not Provided & LLNL & $7.6 \times 10^{15}$ \\
\hline Carbon-14 (pmc) & Not Provided & LLNL & 6.9 \\
\hline Carbon-14 (years, uncorrected) & Not Provided & LLNL & 21,530 \\
\hline Chlorine-36 (atoms/L) & Not Provided & LLNL & $8.5 \times 10^{7}$ \\
\hline Chlorine-36/Cl (ratio) & Not Provided & LLNL & $5.6 \times 10^{-13}$ \\
\hline Delta Carbon-13 (\%) & Not Provided & LLNL & -7.6 \\
\hline Delta Carbon-13 (\%) & Not Provided & DRI & -8.1 \\
\hline Delta Deuterium (\%) & Not Provided & LLNL & -103 \\
\hline Delta Deuterium (\%o) & Not Provided & DRI & -100 \\
\hline Delta Oxygen-18 (\%) & Not Provided & LLNL & -13.7 \\
\hline Delta Oxygen-18 (\%) & Not Provided & DRI & -13.7 \\
\hline Dissolved Organic Carbon-13 (\%) & Not Provided & DRI & -47.7 \\
\hline Dissolved Organic Carbon-14 (pmc) & Not Provided & DRI & 23.4 \\
\hline Helium-3 (atoms/g) & Not Provided & LLNL & $7.8 \times 10^{5}$ \\
\hline Helium-3/4 (ratio) & Not Provided & LLNL & $7.23 \times 10^{-7}$ \\
\hline Helium-3/4, Relative to Air (ratio) & Not Provided & LLNL & 0.52 \\
\hline Helium-4 (atoms/g) & Not Provided & LLNL & $1.1 \times 10^{12}$ \\
\hline Krypton (atoms/g) & Not Provided & LLNL & $1.8 \times 10^{12}$ \\
\hline Neon-20 (atoms/g) & Not Provided & LLNL & $4.5 \times 10^{12}$ \\
\hline Delta Strontium-87 (\%) & Not Provided & LLNL & 2.04 \\
\hline Strontium-87/86 (ratio) & Not Provided & USGS & 0.71041 \\
\hline Strontium-87/86 (ratio) & Not Provided & LLNL & 0.71065 \\
\hline *Strontium-87/86 (ratio) & Not Provided & USGS & \begin{tabular}{ll|l|}
0.71096 & 0.71068 \\
\end{tabular} \\
\hline Uranium-234/235 (ratio) & Not Provided & LLNL & 0.015 \\
\hline Uranium-234/238 (ratio) & Not Provided & LLNL & 0.00011 \\
\hline Uranium-234/238, Activity (ratio) & Not Provided & LLNL & 1.93 \\
\hline Uranium-234/238, Activity (ratio) & Not Provided & USGS & 2.13 \\
\hline *Uranium-234/238, Activity (ratio) & Not Provided & USGS & \begin{tabular}{|l|l|}
2.10 & 2.09 \\
\end{tabular} \\
\hline Uranium-235/238 (ratio) & Not Provided & LLNL & 0.0072 \\
\hline Xenon-130 (atoms/g) & Not Provided & LLNL & $1.2 \times 10^{10}$ \\
\hline \multicolumn{4}{|c|}{ Radiochemistry } \\
\hline Chlorine-36 (pCi/L) & Not Provided & LLNL & 0.00017 \\
\hline Krypton-85 (pCi/L) & 0.5 & LANL & $<0.5$ \\
\hline *Krypton-85 (pCi/L) & 0.5 & LANL & $<0.5$ \\
\hline Tritium $(\mathrm{pCi} / \mathrm{L})$ & 0.5 & LLNL & 89.7 \\
\hline Tritium $(\mathrm{pCi} / \mathrm{L})$ & 500 & LANL & $<500$ \\
\hline${ }^{*}$ Tritium $(\mathrm{pCi} / \mathrm{L})$ & 500 & LANL & $<500$ \\
\hline Uranium-234 (pCi/L) & Not Provided & LLNL & 0.192 \\
\hline Uranium-235 (pCi/L) & Not Provided & LLNL & 0.005 \\
\hline Uranium-238 (pCi/L) & Not Provided & LLNL & 0.099 \\
\hline
\end{tabular}

aDuplicate samples (124-081505-3F [a] and 124-081505-3F [b]) were analyzed by the USGS. The results for each sample are presented. bThe reported carbon-14 age is not corrected for reactions along the flow path.

*Analytical results for samples collected on 4/25/06.

atoms $/ g=$ Atoms per gram

$\mathrm{mV}=$ Millivolt

ND $=$ Not detected

pmc $=$ Percent modern carbon ppb = Parts per billion

$\%$ = Per mil

$\mathrm{SHE}=$ Standard hydrogen electrode

$\mu \mathrm{g} / \mathrm{L}=$ Micrograms per liter 
The ER-12-4 samples are quite dilute with total dissolved solid values ranging from 120 to $150 \mathrm{mg} / \mathrm{L}$. Sulfate (10.7 to $12.3 \mathrm{mg} / \mathrm{L}$ ), silicon (4.8 to $10 \mathrm{mg} / \mathrm{L}$ ), calcium (8.29 to 11.4), potassium (3.02 to $4.52 \mathrm{mg} / \mathrm{L})$, and chloride (8.73 to $9.5 \mathrm{mg} / \mathrm{L}$ ) are present in moderately low concentrations. These concentrations tend to be lower than typically observed in groundwaters of the lower carbonate aquifer (LCA)/LCA3. The samples also have similar slightly basic $\mathrm{pH}$ values $(\mathrm{pH}=8.2$ to 8.8$)$ that are consistent with groundwater of this area. The "J" qualifier associated with the $\mathrm{pH}$ measurement for the April 2006 sample indicates that the analysis was performed outside of the 48-hour holding time. The field-measured $\mathrm{pH}$ (and water temperature) values were $8.72\left(30.8^{\circ} \mathrm{C}\right), 8.75$ to 8.84 (29.6 to $32.4^{\circ} \mathrm{C}$ ), and 7.80 to $8.23\left(24.8\right.$ to $\left.27.4^{\circ} \mathrm{C}\right)$ for samples collected on August 4 and August 15, 2005, and on April 25, 2006, respectively.

A significant number of the analytes in the "metals" section (minor and trace elements) of Table 4-1 were not detected above the method detection limit. This is similarly the case for the minor and trace elements reported in Table 4-2. Because the concentrations of these elements are often present naturally at concentrations near the detection limit, this is not unexpected. The detectable concentrations of most of these elements are relatively similar between all samples collected. The concentration of iron in the filtered samples is lower than in the unfiltered samples (Table 4-1). The concentration of barium is somewhat lower in the samples collected in $2005(<0.015 \mathrm{mg} / \mathrm{L})$ than in the 2006 samples $(0.022 \mathrm{mg} / \mathrm{L})$. A similar trend is observed for vanadium and boron (Table 4-2), whereas an opposite trend is observed for molybdenum and manganese. The elements iron, vanadium, molybdenum, and manganese are sensitive to the redox conditions of the groundwater; therefore, these differences may be due to slight differences in the redox conditions for these samples.

\subsubsection{Environmental Isotopes}

The measured values of delta oxygen-18 $\left(\delta^{18} \mathrm{O}\right)$ were identical for the LLNL and DRI analyses (-13.7 per mil [\%o]). A higher degree of variability was observed for the delta deuterium $(\delta \mathrm{D})$ values; these values ranged from $-103 \%$ (LLNL) to $-100 \%$ (DRI). This is attributed to measurement uncertainty and, although higher than desirable, is not outside of the acceptable limits ( $\pm 3 \%$ ). The delta carbon-13 $\left(\delta^{13} \mathrm{C}\right)$ of dissolved inorganic carbon ranged from -8.1 \%о (DRI) to -7.6 \%о (LLNL). The carbon-14 $\left({ }^{14} \mathrm{C}\right)$ was measured to be 6.9 percent modern carbon (pmc), which resulted in an uncorrected ${ }^{14} \mathrm{C}$ age of approximately 21,530 years. However, the low ${ }^{14} \mathrm{C}$ and the moderately heavy 
$\delta^{13} \mathrm{C}$ are indicative of groundwater interaction with the carbonate host rock causing the measured ${ }^{14} \mathrm{C}$ age to appear older than the actual age of the water (LLNL, 2006). For this reason, a large uncertainty (as high as several thousands of years) is associated with the uncorrected ${ }^{14} \mathrm{C}$ age of this groundwater. The groundwater age for this groundwater will be further evaluated in FY 2007 using geochemical modeling of groundwater flow paths and the water-rock interactions that take place along the flow paths for the Rainier Mesa/Shoshone Mountain CAU. The $\delta^{13} \mathrm{C}$ and ${ }^{14} \mathrm{C}$ associated with the dissolved organic carbon are $-47.7 \%$ and 23.4 pmc, respectively (Table 4-2).

The helium-3/4 $\left({ }^{3} \mathrm{He} /{ }^{4} \mathrm{He}\right)$ ratio in the composite sample $\left(\mathrm{R}=7.23 \times 10^{-7}\right)$ is lower than the natural atmospheric ratio $\left(\mathrm{R}_{\mathrm{a}}=1.38 \times 10^{-6}\right)$ and yields an $\mathrm{R} / \mathrm{R}_{\mathrm{a}}$ of 0.52 . LLNL (2006) reports that the relatively low ${ }^{4} \mathrm{He}\left(1.1 \times 10^{12}\right)$ and ${ }^{3} \mathrm{He}\left(7.8 \times 10^{-5}\right)$ indicate that ER-12-4 groundwater samples are not representative of ambient waters at this well and that noble gases may have been partially lost during sampling. Loss of noble gases may have resulted from the low production rates in this well (LLNL, 2006).

The chlorine-36/ $\mathrm{Cl}\left({ }^{36} \mathrm{Cl} / \mathrm{Cl}\right)$ ratio reported by LLNL, $5.6 \times 10^{-13}$, is in the range of the modern atmospheric ratio for southern Nevada (Fabryka-Martin et al., 1993) but greater than that observed for groundwaters of carbonate aquifers (LCA/LCA3) in Yucca Flat with the exception of those determined to be mixed with groundwaters of a volcanic rock aquifer (SNJV, 2006a). The strontium-87/86 $\left({ }^{87} \mathrm{Sr} /{ }^{86} \mathrm{Sr}\right)$ ratios of 0.71041 to 0.71096 and $\mathrm{Sr}$ concentrations $(0.053$ to $0.083 \mathrm{mg} / \mathrm{L})$ are in general lower than observed in Yucca Flat LCA/LCA3 groundwater (SNJV, 2006a). The elevated ${ }^{36} \mathrm{Cl} / \mathrm{Cl}$ and lower ${ }^{87} \mathrm{Sr} /{ }^{86} \mathrm{Sr}$ suggest mixing of groundwater of the LCA3 with that of the overlying volcanic aquifer (LLNL, 2006).

\subsubsection{Radionuclide Contaminants}

No detectable activity for any of the measured radionuclides was observed in the samples collected by SNJV and analyzed by Paragon Analytics, Inc. (Table 4-1). A detectable amount of tritium (89.7 pCi/L) was measured in the sample collected on August 16, 2005, and analyzed using the helium accumulation method (Surano et al., 1992). The detection limit for this method (approximately $0.5 \mathrm{pCi} / \mathrm{L}$ ) is significantly lower than that of methods used by the other laboratories (300 to $500 \mathrm{pCi} / \mathrm{L}$ ). The presence of tritium may be attributed to mixing with groundwaters from the overlying tuffs above which underground tests were conducted, or may simply be an artifact of 
drilling (LLNL, 2006). It should be noted though that tritium has not been detected in the makeup water from WW-8 that was used during drilling; the tritium activity was reported as $<17 \mathrm{pCi} / \mathrm{L}$ for the most recently collected sample from WW-8 (collected on October 18, 2005). Tritium data obtained using the helium accumulation method for the more recent samples are still pending.

The concentrations of dissolved uranium (0.98 to $0.4 \mu \mathrm{g} / \mathrm{L}$; Table 4-2) were reported to be within the expected range for waters of the LCA. In addition, the uranium-234/238 (U-234/U-238) ratio (1.93 to 2.13) indicates that the uranium is of natural origin (LLNL, 2006).

\subsubsection{Colloids}

Table 4-3 presents the results for the colloid analysis, performed by LANL, of composite samples collected from ER-12-4 on August 15, 2005, and April 25, 2006. Triplicate analyses of two composite samples collected in 2005 (1240-05-110), duplicate analyses of a sample collected in 2006 (1240-06-110), and a single analysis of another 2006 sample (1240-06-140) were performed. The colloid concentrations for each analysis, along with the average concentration for each of the two sampling events, are reported in Table 4-3. Note that the colloid size reported in Table 4-3 is the equivalent spherical diameter (the amount of light scattered by a spherical particle of a given diameter). A decreasing trend is observed in the concentration of colloids as the size increased from 90 to 1,000 nanometers (nm). The total average colloid concentrations for the 2005 and 2006 samples were $1.17 \times 10^{9}$ and $3.92 \times 10^{7}$ particles per milliliter (particles/mL), respectively. Concentrations are over an order of magnitude lower in the 2006 samples. This probably reflects the slow continuous pumping rate that took place during the 2006 sample collection, compared to a higher pumping rate and the cycling on and off of the pump during the 2005 sampling event. The 2006 samples, therefore, are thought to provide a better reflection of colloids in the ambient groundwater.

\subsubsection{Groundwater Oxidation/Reduction Potential}

The Eh/pH conditions of the groundwater are important for predicting the speciation of radionuclides that can exist in multiple oxidation states, most notably $\mathrm{U}$, neptunium (Np), plutonium (Pu), and technetium (Tc). The oxidation state of these radionuclides dictates, to a large extent, their solubility and the sorption characteristics in the groundwater. On-site measurements of $\mathrm{pH}$, oxidation/reduction 
Table 4-3

Colloid Analyses for ER-12-4 Composite Wellhead Samples

\begin{tabular}{|c|c|c|c|c|c|c|c|c|c|c|c|}
\hline \multirow{2}{*}{$\begin{array}{c}\text { Colloid } \\
\text { Particle Size } \\
\text { (nm) }\end{array}$} & \begin{tabular}{|c|}
$1240-05-110-1$ \\
$(9 / 15 / 05)$
\end{tabular} & $\begin{array}{c}1240-05-110-2 \\
(9 / 15 / 05)\end{array}$ & $\begin{array}{c}1240-05-110-3 \\
(9 / 15 / 05)\end{array}$ & $\begin{array}{c}1240-05-120-1 \\
(9 / 15 / 05)\end{array}$ & $\begin{array}{c}1240-05-120-2 \\
(9 / 15 / 05)\end{array}$ & $\begin{array}{c}1240-05-120-3 \\
(9 / 15 / 05)\end{array}$ & \begin{tabular}{|c|}
$1240-06-110-1$ \\
$(4 / 25 / 06)$
\end{tabular} & $\begin{array}{c}1240-06-110-2 \\
(4 / 25 / 06)\end{array}$ & $\begin{array}{c}1240-06-140-1 \\
(4 / 25 / 06)\end{array}$ & $\begin{array}{l}\text { Average } \\
\text { (9/15/05) }\end{array}$ & $\begin{array}{l}\text { Average } \\
(4 / 25 / 06)\end{array}$ \\
\hline & \multicolumn{11}{|c|}{ Concentration (Particles $/ \mathrm{mL}$ ) } \\
\hline 50 & $9.09 \mathrm{E}+07$ & $1.49 \mathrm{E}+08$ & $1.54 \mathrm{E}+08$ & $1.26 \mathrm{E}+08$ & $1.62 \mathrm{E}+08$ & $1.74 \mathrm{E}+08$ & $8.64 \mathrm{E}+06$ & $7.78 \mathrm{E}+06$ & $8.40 \mathrm{E}+06$ & $1.43 \mathrm{E}+08$ & $8.27 \mathrm{E}+06$ \\
\hline 60 & $1.04 \mathrm{E}+08$ & $1.69 \mathrm{E}+08$ & $1.73 \mathrm{E}+08$ & $1.43 E+08$ & $1.80 \mathrm{E}+08$ & $1.82 \mathrm{E}+08$ & $8.87 \mathrm{E}+06$ & $8.39 \mathrm{E}+06$ & $8.73 \mathrm{E}+06$ & $1.59 \mathrm{E}+08$ & $8.66 \mathrm{E}+06$ \\
\hline 70 & $1.01 \mathrm{E}+08$ & $1.61 \mathrm{E}+08$ & $1.72 \mathrm{E}+08$ & $1.38 \mathrm{E}+08$ & $1.74 \mathrm{E}+08$ & $1.80 \mathrm{E}+08$ & $7.48 \mathrm{E}+06$ & $7.11 \mathrm{E}+06$ & $7.18 \mathrm{E}+06$ & $1.54 \mathrm{E}+08$ & $7.25 E+06$ \\
\hline 80 & $8.84 \mathrm{E}+07$ & $1.45 \mathrm{E}+08$ & $1.50 \mathrm{E}+08$ & $1.25 E+08$ & $1.63 E+08$ & $1.66 \mathrm{E}+08$ & $5.59 \mathrm{E}+06$ & $5.60 \mathrm{E}+06$ & $5.31 \mathrm{E}+06$ & $1.40 \mathrm{E}+08$ & $5.50 \mathrm{E}+06$ \\
\hline 90 & $1.32 E+08$ & $2.10 \mathrm{E}+08$ & $2.21 \mathrm{E}+08$ & $1.66 \mathrm{E}+08$ & $2.11 E+08$ & $2.23 E+08$ & $4.18 \mathrm{E}+06$ & $4.08 \mathrm{E}+06$ & $3.94 \mathrm{E}+06$ & $1.94 \mathrm{E}+08$ & $4.07 E+06$ \\
\hline 100 & $5.39 E+07$ & $8.49 \mathrm{E}+07$ & $9.18 \mathrm{E}+07$ & $7.58 \mathrm{E}+07$ & $9.63 E+07$ & $9.59 \mathrm{E}+07$ & $1.24 \mathrm{E}+06$ & $1.24 \mathrm{E}+06$ & $1.16 \mathrm{E}+06$ & $8.31 E+07$ & $1.21 E+06$ \\
\hline 110 & $4.10 \mathrm{E}+07$ & $6.41 E+07$ & $6.80 \mathrm{E}+07$ & $5.10 E+07$ & $6.73 E+07$ & $7.21 \mathrm{E}+07$ & $9.80 \mathrm{E}+05$ & $1.11 \mathrm{E}+06$ & $9.26 \mathrm{E}+05$ & $6.06 \mathrm{E}+07$ & $1.00 E+06$ \\
\hline 120 & $2.98 \mathrm{E}+07$ & $4.86 \mathrm{E}+07$ & $5.09 E+07$ & $4.00 E+07$ & $5.07 \mathrm{E}+07$ & $4.95 E+07$ & $6.75 \mathrm{E}+05$ & $6.60 \mathrm{E}+05$ & $5.65 E+05$ & $4.49 \mathrm{E}+07$ & $6.34 E+05$ \\
\hline 130 & $2.28 \mathrm{E}+07$ & $4.08 \mathrm{E}+07$ & $4.14 \mathrm{E}+07$ & $3.36 \mathrm{E}+07$ & $4.30 \mathrm{E}+07$ & $4.34 \mathrm{E}+07$ & $4.90 \mathrm{E}+05$ & $4.90 \mathrm{E}+05$ & $5.00 \mathrm{E}+05$ & $3.75 \mathrm{E}+07$ & $4.94 \mathrm{E}+05$ \\
\hline 140 & $2.05 \mathrm{E}+07$ & $3.66 \mathrm{E}+07$ & $3.86 \mathrm{E}+07$ & $2.82 \mathrm{E}+07$ & $3.67 \mathrm{E}+07$ & $3.79 \mathrm{E}+07$ & $3.95 \mathrm{E}+05$ & $4.45 \mathrm{E}+05$ & $3.85 \mathrm{E}+05$ & $3.31 \mathrm{E}+07$ & $4.09 E+05$ \\
\hline 150 & $1.91 \mathrm{E}+07$ & $2.67 \mathrm{E}+07$ & $2.72 E+07$ & $2.56 \mathrm{E}+07$ & $3.00 \mathrm{E}+07$ & $3.21 \mathrm{E}+07$ & $3.00 \mathrm{E}+05$ & $3.35 E+05$ & $2.60 \mathrm{E}+05$ & $2.68 \mathrm{E}+07$ & $2.98 E+05$ \\
\hline 160 & $1.34 \mathrm{E}+07$ & $2.07 \mathrm{E}+07$ & $2.37 \mathrm{E}+07$ & $1.95 \mathrm{E}+07$ & $2.90 \mathrm{E}+07$ & $2.55 \mathrm{E}+07$ & $2.15 E+05$ & $2.48 \mathrm{E}+05$ & $2.50 \mathrm{E}+05$ & $2.20 \mathrm{E}+07$ & $2.38 \mathrm{E}+05$ \\
\hline 170 & $1.25 \mathrm{E}+07$ & $1.87 \mathrm{E}+07$ & $2.02 E+07$ & $1.77 \mathrm{E}+07$ & $2.09 E+07$ & $2.09 \mathrm{E}+07$ & $1.70 \mathrm{E}+05$ & $2.28 \mathrm{E}+05$ & $1.85 \mathrm{E}+05$ & $1.85 \mathrm{E}+07$ & $1.94 \mathrm{E}+05$ \\
\hline 180 & $1.10 \mathrm{E}+07$ & $1.65 E+07$ & $1.84 \mathrm{E}+07$ & $1.09 \mathrm{E}+07$ & $1.83 E+07$ & $1.94 \mathrm{E}+07$ & $1.70 \mathrm{E}+05$ & $1.65 \mathrm{E}+05$ & $1.45 \mathrm{E}+05$ & $1.58 \mathrm{E}+07$ & $1.60 E+05$ \\
\hline 190 & $8.29 \mathrm{E}+06$ & $1.38 \mathrm{E}+07$ & $1.42 E+07$ & $1.04 \mathrm{E}+07$ & $1.60 \mathrm{E}+07$ & $1.63 \mathrm{E}+07$ & $1.45 \mathrm{E}+05$ & $1.73 \mathrm{E}+05$ & $1.55 \mathrm{E}+05$ & $1.32 \mathrm{E}+07$ & $1.58 \mathrm{E}+05$ \\
\hline 200 & $7.66 \mathrm{E}+06$ & $1.30 \mathrm{E}+07$ & $1.37 \mathrm{E}+07$ & $1.08 \mathrm{E}+07$ & $1.38 \mathrm{E}+07$ & $1.41 \mathrm{E}+07$ & $2.66 \mathrm{E}+05$ & $3.16 \mathrm{E}+05$ & $2.11 \mathrm{E}+05$ & $1.22 \mathrm{E}+07$ & $2.64 E+05$ \\
\hline 220 & $3.10 \mathrm{E}+06$ & $5.35 \mathrm{E}+06$ & $5.64 \mathrm{E}+06$ & $4.57 \mathrm{E}+06$ & $6.01 \mathrm{E}+06$ & $6.00 \mathrm{E}+06$ & $1.08 \mathrm{E}+05$ & $1.18 \mathrm{E}+05$ & $7.96 \mathrm{E}+04$ & $5.11 \mathrm{E}+06$ & $1.02 \mathrm{E}+05$ \\
\hline 240 & $1.97 \mathrm{E}+06$ & $3.48 \mathrm{E}+06$ & $3.74 \mathrm{E}+06$ & $3.02 E+06$ & $4.03 E+06$ & $4.00 \mathrm{E}+06$ & $7.02 \mathrm{E}+04$ & $8.46 \mathrm{E}+04$ & $4.57 \mathrm{E}+04$ & $3.37 \mathrm{E}+06$ & $6.69 \mathrm{E}+04$ \\
\hline 260 & $1.38 \mathrm{E}+06$ & $2.24 \mathrm{E}+06$ & $2.21 \mathrm{E}+06$ & $1.85 \mathrm{E}+06$ & $2.51 \mathrm{E}+06$ & $2.57 \mathrm{E}+06$ & $4.22 \mathrm{E}+04$ & $4.96 \mathrm{E}+04$ & $2.78 \mathrm{E}+04$ & $2.13 \mathrm{E}+06$ & $3.98 \mathrm{E}+04$ \\
\hline 280 & $7.76 \mathrm{E}+05$ & $1.26 \mathrm{E}+06$ & $1.29 \mathrm{E}+06$ & $1.09 \mathrm{E}+06$ & $1.30 \mathrm{E}+06$ & $1.40 \mathrm{E}+06$ & $2.70 \mathrm{E}+04$ & $3.00 \mathrm{E}+04$ & $1.61 \mathrm{E}+04$ & $1.19 \mathrm{E}+06$ & $2.44 \mathrm{E}+04$ \\
\hline 300 & $1.80 \mathrm{E}+06$ & $2.86 \mathrm{E}+06$ & $3.21 \mathrm{E}+06$ & $2.61 \mathrm{E}+06$ & $3.48 \mathrm{E}+06$ & $3.56 \mathrm{E}+06$ & $6.61 \mathrm{E}+04$ & $7.19 \mathrm{E}+04$ & $4.06 \mathrm{E}+04$ & $2.92 \mathrm{E}+06$ & $5.95 E+04$ \\
\hline 400 & $4.21 \mathrm{E}+05$ & $7.16 \mathrm{E}+05$ & $7.87 \mathrm{E}+05$ & $6.72 E+05$ & $7.82 E+05$ & $8.78 \mathrm{E}+05$ & $1.41 \mathrm{E}+04$ & $1.55 \mathrm{E}+04$ & $7.28 \mathrm{E}+03$ & $7.09 \mathrm{E}+05$ & $1.23 E+04$ \\
\hline 500 & $4.58 \mathrm{E}+05$ & $8.52 \mathrm{E}+05$ & $8.63 E+05$ & $8.04 \mathrm{E}+05$ & $1.19 \mathrm{E}+06$ & $1.11 \mathrm{E}+06$ & $1.40 \mathrm{E}+04$ & $1.58 \mathrm{E}+04$ & $6.80 \mathrm{E}+03$ & $8.80 \mathrm{E}+05$ & $1.22 \mathrm{E}+04$ \\
\hline 600 & $7.65 \mathrm{E}+05$ & $1.29 \mathrm{E}+06$ & $1.40 \mathrm{E}+06$ & $1.47 \mathrm{E}+06$ & $1.76 \mathrm{E}+06$ & $1.93 E+06$ & $1.22 \mathrm{E}+04$ & $1.44 \mathrm{E}+04$ & $8.32 \mathrm{E}+03$ & $1.44 \mathrm{E}+06$ & $1.16 \mathrm{E}+04$ \\
\hline 800 & $2.28 \mathrm{E}+05$ & $4.05 E+05$ & $3.77 \mathrm{E}+05$ & $5.18 \mathrm{E}+05$ & $5.89 \mathrm{E}+05$ & $6.09 \mathrm{E}+05$ & $1.52 \mathrm{E}+03$ & $2.16 \mathrm{E}+03$ & $1.52 \mathrm{E}+03$ & $4.54 \mathrm{E}+05$ & $1.73 \mathrm{E}+03$ \\
\hline 1,000 & $2.58 \mathrm{E}+05$ & $4.08 \mathrm{E}+05$ & $4.83 E+05$ & $6.00 \mathrm{E}+05$ & $7.41 \mathrm{E}+05$ & $7.04 \mathrm{E}+05$ & $3.84 \mathrm{E}+03$ & $6.64 \mathrm{E}+03$ & $6.72 \mathrm{E}+03$ & $5.32 \mathrm{E}+05$ & $5.73 E+03$ \\
\hline \begin{tabular}{c|} 
Total \\
Concentration \\
$(50-1,000 \mathrm{~nm})$
\end{tabular} & $7.68 \mathrm{E}+08$ & $1.24 \mathrm{E}+09$ & $1.30 \mathrm{E}+09$ & 1.04E+09 & 1.33E+09 & 1.37E+09 & $4.02 \mathrm{E}+07$ & $3.88 \mathrm{E}+07$ & $3.85 \mathrm{E}+07$ & $1.17 \mathrm{E}+09$ & $3.92 \mathrm{E}+07$ \\
\hline
\end{tabular}

\section{Uncontrolled When Printed}


potentials (converted to Eh in millivolts [mV] vs. standard hydrogen electrode [SHE]), dissolved oxygen concentrations, and redox couple concentrations (total iron $\left[\mathrm{Fe}_{\mathrm{T}}\right] /$ iron(II) $\left[\mathrm{Fe}^{2+}\right]$, total manganese $\left(\mathrm{Mn}_{\mathrm{T}}\right)$, nitrate $\left[\mathrm{NO}_{3}^{-}\right] /$nitrite $\left[\mathrm{NO}_{2}^{-}\right] /$ammonia $\left.\left[\mathrm{NH}_{3}\right]\right)$ were conducted by LANL on April 25,2006 . The objective of these measurements was to identify appropriate groundwater Eh/pH conditions for radionuclide transport modeling in the LCA at this location. The measurements were performed on location because many of the measured parameters are time sensitive, particularly if the groundwater is reducing before being pumped to the surface. Multiple indicators of

oxidation/reduction potential are measured to reduce uncertainty relative to that of a single parameter (redox measurements are notorious for potential artifacts, so multiple parameters increase confidence in results). Also, multiple indicators can help identify mixing of reducing and oxidizing groundwaters from different producing zones in the wellbore (e.g., the simultaneous presence of dissolved oxygen with a significant $\mathrm{Fe}^{2+}$ concentration is a good indication that an oxidizing water containing oxygen is mixing with a reducing water containing $\mathrm{Fe}^{2+}$ ).

A multiprobe equipped with a flow-through cell was used by LANL to continuously measure water temperature, specific conductance, dissolved oxygen concentration, $\mathrm{pH}$, and oxidation/reduction potential. The results are presented in Figure 4-1 and provided electronically in Appendix B. The redox couple concentrations, determined by LANL, are presented in Table 4-2. The on-site measurements were all indicative of an oxidizing groundwater with an Eh ranging from +300 to +700 $\mathrm{mV}$. The low end of this range is based on the direct Eh measurement of the groundwater (platinum [Pt] electrode vs. silver [Ag]/ silver chloride [AgCl] electrode corrected to $+332 \mathrm{mV}$ vs. SHE), and the high end is based on a dissolved oxygen concentration of $2.9 \mathrm{mg} / \mathrm{L}$, which is consistent with an Eh of $+695 \mathrm{mV}$ vs. SHE. Measurement of $\mathrm{Mn}_{\mathrm{T}}$ and $\mathrm{NO}_{3}{ }^{-/} \mathrm{NO}_{2}^{-}$yielded Eh values of approximately +400 $\mathrm{mV}$ vs. SHE. Given these Eh values and a $\mathrm{pH}$ of 8.5 to 8.6, the redox-sensitive radionuclides of interest would all tend to be in their more soluble and less-sorbing higher oxidation states. Specifically, $\mathrm{U}$ would be in the +6 oxidation state, predominantly present as $\mathrm{UO}_{2}{ }^{2+}$ (uranyl ion) complexed to carbonate (Figure 4-2a); Np would be in the +5 oxidation state, predominantly present as $\mathrm{NpO}_{2}^{+}$(neptunyl ion) or as a neptunyl carbonate complex (Figure 4-2b); Pu would be in either the +4 or +5 oxidation state, with the +5 state $\left(\mathrm{PuO}_{2}^{+}\right)$probably complexed with carbonate (Figure 4-2c); and Tc would be in the +7 oxidation state, predominantly present as $\mathrm{TcO}_{4}^{-}$(pertechnetate ion; Figure 4-2d). 


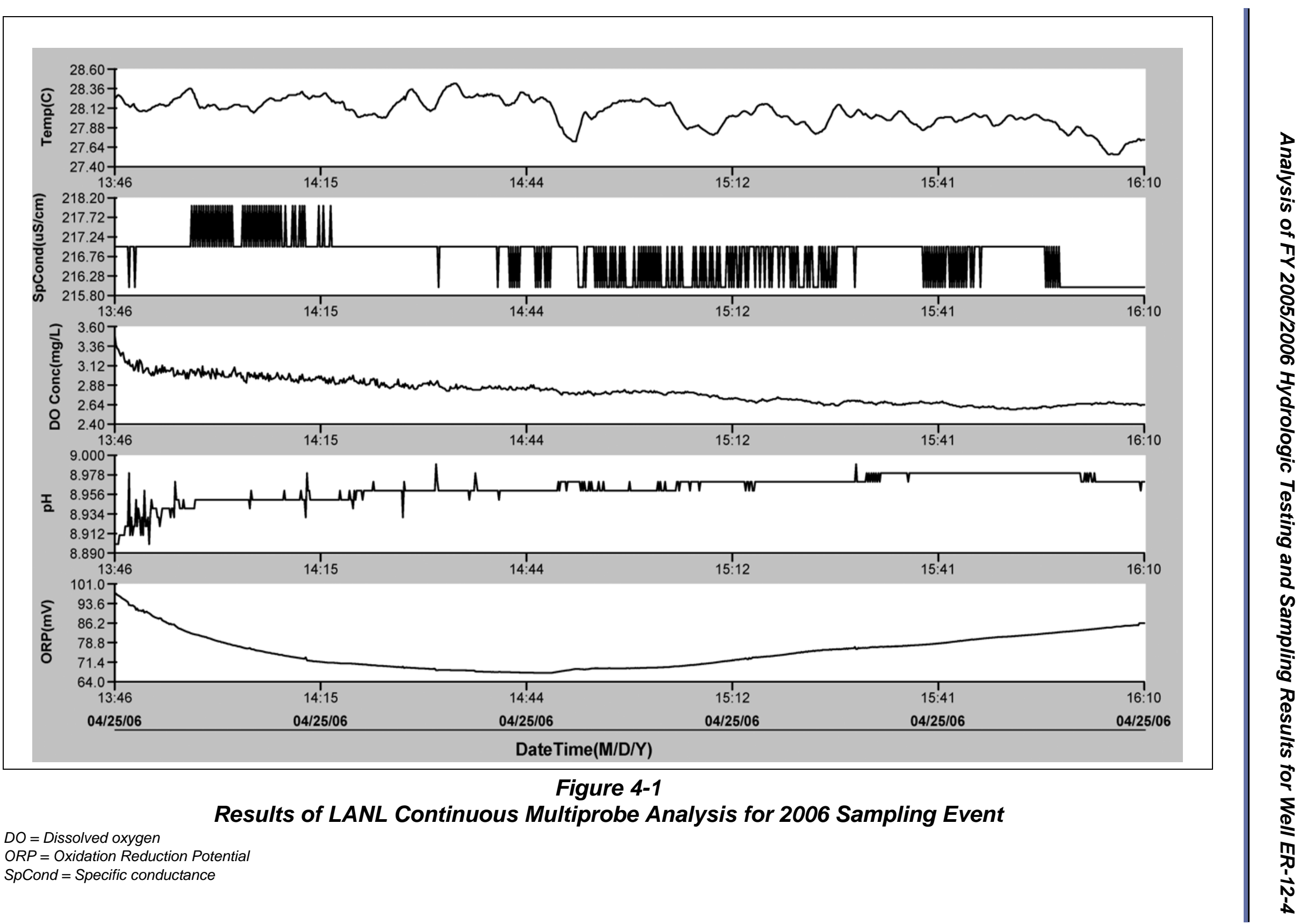




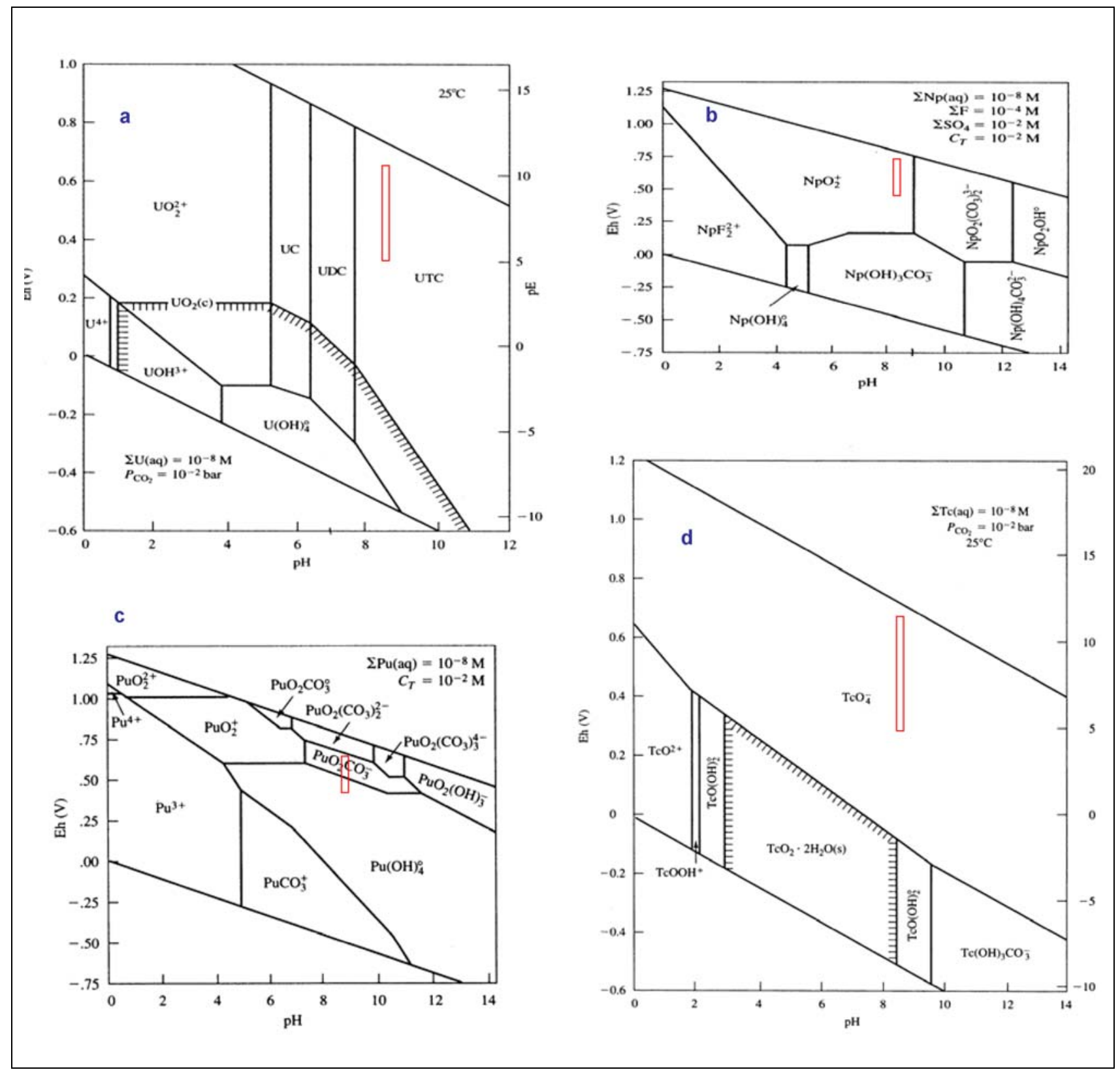

Figure 4-2

\section{Eh-pH Diagrams for $\mathrm{U}, \mathrm{Np}, \mathrm{Pu}$, and TC}

Note: Diagrams are modified from Langmuir (1997) for aqueous species in pure water at $25^{\circ} \mathrm{C}$ and 1 bar total pressure and include the range of values determined for ER-12-4 groundwaters during the April 26, 2006, sampling event (red bar).

a) $\mathrm{U}-\mathrm{O}_{2}-\mathrm{CO}_{2}-\mathrm{H}_{2} \mathrm{O}$ system where the total concentration of $U$ is $10^{-8} \mathrm{Molar}(\mathrm{M})$ and partial pressure of $\mathrm{CO}_{2}\left(P_{\mathrm{CO} 2}\right)$ is $10^{-2}$ bar; UC, UDC, and UTC denote the aqueous complexes $\mathrm{UO}_{2} \mathrm{CO}_{3}, \mathrm{UO}_{2}\left(\mathrm{CO}_{3}\right)_{2}^{2-}$, and $\mathrm{UO}_{2}\left(\mathrm{CO}_{3}\right)_{3}{ }^{4-}$, respectively.

b) $\mathrm{Np}-\mathrm{O}_{2}-\mathrm{F}-\mathrm{SO}_{4}-\mathrm{CO}_{2}-\mathrm{H}_{2} \mathrm{O}$ system where the total concentration of $\mathrm{Np}$ is $10^{-8} \mathrm{M}$ and total carbonate $\left(\mathrm{C}_{\mathrm{T}}\right)$ is $10^{-2} \mathrm{M}$.

c) $\mathrm{Pu}-\mathrm{O}_{2}-\mathrm{CO}_{2}-\mathrm{H}_{2} \mathrm{O}$ system where the total concentration of $\mathrm{Pu}$ is $10^{-8} \mathrm{M}$ and $\mathrm{C}_{\mathrm{T}}$ is $10^{-2} \mathrm{M}$.

d) $\mathrm{TC}-\mathrm{O}_{2}-\mathrm{CO}_{2}-\mathrm{H}_{2} \mathrm{O}$ system where the total concentration of Tc is $10^{-8} \mathrm{M}$ and $\mathrm{P}_{\mathrm{CO} 2}$ is $10^{-2}$ bar. 


\subsection{Comparison of ER-12-4 Groundwater Chemistry to Surrounding Wells}

Table 4-4 presents groundwater chemistry data for ER-12-4 and for selected wells and tunnel seeps in its vicinity (see Figure 1-2). These data were obtained from the Comprehensive Groundwater Chemistry Database, Geochem05.mdb (SNJV, 2005a). Table 4-4 shows the analytical results for selected major, minor, and trace constituents; physical parameters; and environmental isotopes, and tritium (if available). The dissolved concentrations are reported for all parameters with the exception of $\mathrm{HCO}_{3}$, carbonate, specific conductance, the environmental isotopes, and tritium; the total concentrations were reported for these parameters. In general, the most recent samples that contain the most complete suite of key analytes were selected for this comparison. For those cases where multiple samples were collected on the same date and analyzed for the same parameters, the mean and the range of the results are presented in Table 4-4. Samples collected on different dates were combined in some cases so that a more complete suite of parameters were available for the evaluation.

The groundwater sampling locations in the vicinity of ER-12-4 are shown in Figure 1-2. Three sampling locations shown in Figure 1-2 are not presented in Table 4-4, nor are they included in this comparison. These wells are identified below and a brief explanation for their exclusion is provided.

- Hagestad \#1 produces groundwater from the lower tuff confining unit (LTCU). Samples from this well were collected in 1958 and analyzed for physical parameters, major constituents, and a few minor constituents. No environmental isotope data are available. A high $\mathrm{pH}$ of the groundwater (10.3 to 11.1) indicates poor well development and contamination from cement during well construction.

- Well ER-19-1 consists of three piezometer strings that produce groundwater from the lower clastic confining unit 1 - thrust plate (LCCU1, String \#1), the Redrock Valley Aquifer (RVA, String \#2), and the Oak Spring Butte Confining Unit (OSBCU, String \#3). A high groundwater $\mathrm{pH}$ is observed in samples from all strings (10.4 to 11.5; SNJV, 2005a), indicating poor well development and contamination from cement during well construction.

- Well UE-2ce produces groundwater from the LCA3 near the NASH test cavity in Yucca Flat. Groundwaters of this well have been impacted by the NASH test; tritium activities as high as $35,000,000 \mathrm{pCi} / \mathrm{L}$ have been measured in this well. 


\begin{tabular}{|c|c|c|c|c|c|c|c|c|c|c|c|c|c|c|c|c|}
\hline$\stackrel{\Delta}{\Delta} \mid$ & \multicolumn{16}{|c|}{$\begin{array}{l}\text { Groundwater Chemistry Data for ER-12-4 and Surrounding Area } \\
\text { (Page } 1 \text { of 2) }\end{array}$} \\
\hline & & \multicolumn{2}{|c|}{ ER-12-4 } & \multirow{2}{*}{$\begin{array}{c}\text { ER-12-3 } \\
\begin{array}{c}\text { Composite } \\
7 / 06 / 05\end{array}\end{array}$} & \multirow{2}{*}{$\begin{array}{ll}\text { ER-12-1 } \\
12 / 08 / 04\end{array}$} & \multirow{2}{*}{ TW-1 } & \multirow{2}{*}{ U-12s } & \multirow{2}{*}{$\begin{array}{c}\text { ER-12-2 } \\
4 / 01 / 03\end{array}$} & \multirow{2}{*}{\begin{tabular}{|c|} 
U12n.05 \\
$\begin{array}{c}7 / 01 / 84 \\
\text { to } 8 / 16 / 86\end{array}$ \\
\end{tabular}} & \multirow{2}{*}{\begin{tabular}{|l|l|l|l|l|l} 
U12n.03 & \\
$5 / 09 / 86$ &
\end{tabular}} & \multirow{2}{*}{\begin{tabular}{c|c|c|} 
U12t \\
$11 / 20 / 72$
\end{tabular}} & \multirow{2}{*}{ UE-10j-1 } & \multirow{2}{*}{$\begin{array}{ll}\text { UE-10j-2 } \\
3 / 20 / 97\end{array}$} & \multirow{2}{*}{\begin{tabular}{|c|} 
UE-10j-3 \\
$3 / 24 / 97$
\end{tabular}} & \multirow{2}{*}{ WW-2 } & \multirow{2}{*}{$\begin{array}{l}\text { WW-8 } \\
11 / 04 / 97\end{array}$} \\
\hline & & $\begin{array}{c}\text { Discrete } \\
\text { Bailer } \\
8 / 04 / 05\end{array}$ & $\begin{array}{c}\text { Composite } \\
8 / 15 / 05 \text { to } \\
4 / 25 / 06\end{array}$ & & & & & & & & & & & & & \\
\hline & \multicolumn{16}{|c|}{ Physical Parameters } \\
\hline & $\mathrm{pH}$ & 8.21 & $\begin{array}{c}8.7 \\
(8.4 / 8.8)\end{array}$ & $\begin{array}{c}8.1 \\
(8.0 / 8.2)\end{array}$ & $\begin{array}{c}7.6 \\
(7.4 / 8.0)\end{array}$ & $\begin{array}{c}8.9 \\
(8.7 / 9.2)\end{array}$ & 10.45 & $\begin{array}{c}8.1 \\
(7.6 / 8.3)\end{array}$ & $\begin{array}{c}8.1 \\
(7.7 / 8.5)\end{array}$ & $\begin{array}{c}8.1 \\
(7.7 / 8.6)\end{array}$ & $\begin{array}{c}7.6 \\
(7.0 / 8.21)\end{array}$ & $\begin{array}{c}6.6 \\
(6.4 / 6.7)\end{array}$ & 6.7 & $\begin{array}{c}7.1 \\
(7.0 / 7.2)\end{array}$ & 8.3 & $\begin{array}{c}7.5 \\
(7.4 / 7.6)\end{array}$ \\
\hline & Specific Conductance & 211 & $\begin{array}{c}205 \\
(196 / 209)\end{array}$ & $\begin{array}{c}290 \\
(279 / 306)\end{array}$ & \begin{tabular}{|c|}
993 \\
$(976 / 1010)$
\end{tabular} & $\begin{array}{c}238 \\
(223 / 245)\end{array}$ & 632 & \begin{tabular}{|c|}
543 \\
$(528 / 550)$
\end{tabular} & $\begin{array}{c}342 \\
(316 / 362)\end{array}$ & \begin{tabular}{|c|}
330 \\
$(325 / 334)$
\end{tabular} & 291 & $\begin{array}{c}1079 \\
(1070 / 1087)\end{array}$ & 725 & \begin{tabular}{c|}
625 \\
$(589 / 661)$
\end{tabular} & 270 & $\begin{array}{c}198 \\
(193 / 201)\end{array}$ \\
\hline & Water Temperature $\left({ }^{\circ} \mathrm{C}\right)$ & 30.8 & \begin{tabular}{c|}
29.7 \\
$(23.9 / 32.4)$
\end{tabular} & 30.6 & 25.0 & $26.6^{\mathrm{b}}$ & 26.1 & 35.2 & NM & NM & NM & 32.7 & 32.3 & 32.1 & 26 & $\begin{array}{c}24.2 \\
(23.4 / 24.7)\end{array}$ \\
\hline & \multicolumn{16}{|c|}{ Major Constituents (mg/L) } \\
\hline & Bicarbonate & 81.1 & \begin{tabular}{c|}
87.8 \\
$(81.4 / 92.6)$
\end{tabular} & $\begin{array}{c}121 \\
(120 / 122)\end{array}$ & \begin{tabular}{c|}
221 \\
$(209 / 238)$
\end{tabular} & $\begin{array}{c}110 \\
(87 / 123)\end{array}$ & 146 & \begin{tabular}{|c|}
298 \\
$(286 / 305)$
\end{tabular} & $\begin{array}{c}200 \\
(187 / 212)\end{array}$ & 191 & 150 & $\begin{array}{c}552 \\
(504 / 600)\end{array}$ & 403 & \begin{tabular}{|c|}
322 \\
$(295 / 349)$
\end{tabular} & 144 & $\begin{array}{c}74.9 \\
(63.4 / 84.7)\end{array}$ \\
\hline & Calcium & 10.6 & $\begin{array}{c}8.8 \\
(8.3 / 10.6)\end{array}$ & $\begin{array}{c}16.7 \\
(13.8 / 17.9)\end{array}$ & $\begin{array}{c}97.7 \\
(88.4 / 102)\end{array}$ & $\begin{array}{c}4.6 \\
(2.0 / 5.9)\end{array}$ & 35.6 & $\begin{array}{c}5.8 \\
(5.5 / 6.5)\end{array}$ & $\begin{array}{c}12.2 \\
(10.8 / 13.0)\end{array}$ & $\begin{array}{c}5.7 \\
(5.5 / 5.8)\end{array}$ & 2.9 & $\begin{array}{c}107 \\
(101 / 113)\end{array}$ & 68 & $\begin{array}{c}60 \\
(56 / 64)\end{array}$ & 14 & $\begin{array}{c}7.9 \\
(7.4 / 8.62)\end{array}$ \\
\hline & Carbonate & $<3$ & $\begin{array}{c}0.9 \\
(0.5 / 1.4)\end{array}$ & $\begin{array}{c}1 \\
(<0.6 / 1)\end{array}$ & $\begin{array}{c}<0.3 \\
(<0.3 /<0.3)\end{array}$ & $\begin{array}{c}12.5 \\
(7.8 / 20.6)\end{array}$ & NM & $\begin{array}{c}5.5 \\
(2.0 / 7.2)\end{array}$ & $\begin{array}{c}5.6 \\
(4.8 / 6.3)\end{array}$ & NM & NM & $\begin{array}{c}0.1 \\
(<6 / 0.1)\end{array}$ & 0.1 & $\begin{array}{c}0.2 \\
(<6 / 0.2)\end{array}$ & $<0.3$ & NM \\
\hline & Chloride & 8.73 & $\begin{array}{c}9.1 \\
(8.9 / 9.5)\end{array}$ & $\begin{array}{c}5.8 \\
(5.7 / 6.0)\end{array}$ & \begin{tabular}{c|}
17.2 \\
$(16.8 / 17.7)$
\end{tabular} & $\begin{array}{c}3.7 \\
(3.4 / 3.8)\end{array}$ & 14 & $\begin{array}{c}6.9 \\
(6.9 / 7.0)\end{array}$ & $\begin{array}{c}8.3 \\
(7.8 / 8.8)\end{array}$ & $\begin{array}{c}6.7 \\
(6.6 / 7.1)\end{array}$ & 13 & $\begin{array}{c}24 \\
(23.7 / 24)\end{array}$ & 16 & \begin{tabular}{c|}
12.8 \\
$(12.5 / 13.1)$
\end{tabular} & 15.1 & $\begin{array}{c}7.3 \\
(7.0 / 7.7)\end{array}$ \\
\hline & Magnesium & 3.72 & $\begin{array}{c}3.2 \\
(3 / 3.5)\end{array}$ & $\begin{array}{c}8.3 \\
(7.9 / 8.6)\end{array}$ & \begin{tabular}{|c|}
64.9 \\
$(58.8 / 69.8)$
\end{tabular} & $\begin{array}{c}0.3 \\
(0.2 / 0.4)\end{array}$ & 0.13 & $\begin{array}{c}2.0 \\
(1.9 / 2.1)\end{array}$ & $\begin{array}{c}2.7 \\
(0.6 / 4.8)\end{array}$ & \begin{tabular}{c|}
0.26 \\
$(0.25 / 0.28)$ \\
\end{tabular} & 0.1 & $\begin{array}{c}44.7 \\
(42.3 / 47.1)\end{array}$ & 30 & \begin{tabular}{c|}
26.8 \\
$(25.4 / 28.1)$ \\
\end{tabular} & 8.6 & $\begin{array}{c}11.2 \\
(1.2 / 1.24)\end{array}$ \\
\hline & Potassium & 4.52 & $\begin{array}{c}3.5 \\
(3.0 / 4.0)\end{array}$ & $\begin{array}{c}2.4 \\
(2.2 / 2.8)\end{array}$ & $\begin{array}{c}3.2 \\
(3.0 / 3.4)\end{array}$ & $\begin{array}{c}0.9 \\
(0.4 / 1.2)\end{array}$ & 5 & $\begin{array}{c}3.0 \\
(2.1 / 3.5)\end{array}$ & $\begin{array}{c}8.0 \\
(7.7 / 8.4)\end{array}$ & $\begin{array}{c}5.8 \\
(5.4 / 6.6)\end{array}$ & 3.6 & $\begin{array}{c}13 \\
(12.3 / 14)\end{array}$ & 8.3 & $\begin{array}{c}7.3 \\
(6.9 / 7.7)\end{array}$ & 6.6 & $\begin{array}{c}3.32 \\
(3.23 / 3.49)\end{array}$ \\
\hline & Sodium & 31.5 & $\begin{array}{c}26.3 \\
(25 / 28.3)\end{array}$ & $\begin{array}{c}29.9 \\
(29.4 / 30.7)\end{array}$ & \begin{tabular}{|c|}
37.9 \\
$(36.4 / 38.6)$
\end{tabular} & $\begin{array}{c}52 \\
(50.0 / 53.5)\end{array}$ & 24 & $\begin{array}{c}112 \\
(110 / 117)\end{array}$ & $\begin{array}{c}64.0 \\
(60.7 / 68.3)\end{array}$ & \begin{tabular}{c|}
69.7 \\
$(68.6 / 70.7)$
\end{tabular} & 68 & $\begin{array}{c}68 \\
(64 / 72.4)\end{array}$ & 43 & $\begin{array}{c}37 \\
(35 / 38.6)\end{array}$ & 30.7 & $\begin{array}{c}31.1 \\
(30.8 / 31.5)\end{array}$ \\
\hline & Sulfate & 11.6 & $\begin{array}{c}11.6 \\
(10.7 / 12.3)\end{array}$ & $\begin{array}{c}25.8 \\
(24.6 / 27.7)\end{array}$ & $\begin{array}{c}346 \\
(332 / 356)\end{array}$ & $\begin{array}{c}8.7 \\
(7.0 / 9.7)\end{array}$ & $<1$ & $\begin{array}{c}27.1 \\
(27.0 / 27.4)\end{array}$ & $\begin{array}{c}12.5 \\
(8.8 / 17.2)\end{array}$ & \begin{tabular}{c|}
12.8 \\
$(11.1 / 14.0)$
\end{tabular} & 18 & $\begin{array}{c}79 \\
(75.5 / 83)\end{array}$ & 67 & \begin{tabular}{c|}
58.5 \\
$(56.2 / 60.8)$
\end{tabular} & 8 & $\begin{array}{c}15 \\
(15 / 15)\end{array}$ \\
\hline & \multicolumn{16}{|c|}{ Minor and Trace Constituents } \\
\hline & Aluminum $(\mu \mathrm{g} / \mathrm{L})$ & $<200$ & $\begin{array}{c}1.7 \\
(<200 / 1.7)\end{array}$ & $\begin{array}{c}1.1 \\
(<60 / 1.1)\end{array}$ & $\begin{array}{c}4.9 \\
(0.32 / 9.5)\end{array}$ & $<60^{\mathrm{b}}$ & $<60$ & $<50$ & NM & NM & $<10$ & $<60$ & $<60$ & $<60$ & NM & $\begin{array}{c}3.4 \\
(2.1 / 5.9)\end{array}$ \\
\hline & Arsenic $(\mu \mathrm{g} / \mathrm{L})$ & $<10$ & $\begin{array}{c}3 \\
(<3 / 3.5)\end{array}$ & $\begin{array}{c}7 \\
(5 / 7)\end{array}$ & $\begin{array}{c}64 \\
(50 / 106)\end{array}$ & $<100^{\circ}$ & $<1$ & $\begin{array}{c}5 \\
(<20 / 5)\end{array}$ & NM & NM & NM & 30 & 18 & 16 & NM & $\begin{array}{c}2 \\
(2 / 2)\end{array}$ \\
\hline & Boron (mg/L) & NM & \begin{tabular}{c|}
0.06 \\
$(<0.05 / 0.06)$
\end{tabular} & $\begin{array}{c}0.06 \\
(0.06 / 0.06)\end{array}$ & \begin{tabular}{c|}
0.07 \\
$(0.07 / 0.07)$ \\
\end{tabular} & $<0.06^{b}$ & 0.06 & $\begin{array}{c}0.22 \\
(0.11 / 0.45)\end{array}$ & NM & NM & NM & 0.55 & 0.33 & 0.25 & NM & NM \\
\hline & Barium (mg/L) & 0.01 & $\begin{array}{c}0.02 \\
(0.01 / 0.02)\end{array}$ & $\begin{array}{c}0.02 \\
(0.02 / 0.02)\end{array}$ & $\begin{array}{c}0.03 \\
(0.02 / 0.03)\end{array}$ & $<0.01^{b}$ & 0.166 & $\begin{array}{c}0.20 \\
(0.19 / 0.21)\end{array}$ & NM & NM & NM & 0.10 & 0.07 & 0.05 & NM & $\begin{array}{l}0.0001 \\
(0.0001 / \\
0.0001)\end{array}$ \\
\hline \multirow{3}{*}{ 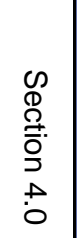 } & Chromium ( $\mu \mathrm{g} / \mathrm{L})$ & $<10$ & $\begin{array}{c}4.5 \\
(<4.5 / 4.5)\end{array}$ & $\begin{array}{c}<3 \\
(<3 /<5)\end{array}$ & $<5$ & NM & NM & $<5$ & NM & NM & NM & NM & NM & NM & NM & $\begin{array}{c}0.2 \\
(0.2 / 0.2)\end{array}$ \\
\hline & Bromide (mg/L) & $<0.5$ & \begin{tabular}{c|}
0.3 \\
$(0.09 / 0.46)$
\end{tabular} & $\begin{array}{c}0.06 \\
(<0.1 / 0.06)\end{array}$ & \begin{tabular}{c|}
0.4 \\
$(<0.5 / 0.4)$
\end{tabular} & NM & NM & $\begin{array}{c}0.4 \\
(0.2 /<0.7)\end{array}$ & 0.035 & 0.045 & NM & 0.1 & NM & 0.1 & NM & $\begin{array}{c}0.05 \\
(0.05 / 0.06)\end{array}$ \\
\hline & Fluoride (mg/L) & 0.72 & $\begin{array}{c}0.7 \\
(0.3 / 0.8)\end{array}$ & $\begin{array}{c}1.6 \\
(1.5 / 1.6)\end{array}$ & \begin{tabular}{c|}
0.2 \\
$(<0.25 / 0.25)$
\end{tabular} & NM & $<1$ & $\begin{array}{c}2.2 \\
(2.2 / 2.2)\end{array}$ & NM & NM & 0.1 & $\begin{array}{c}0.3 \\
(<3 / 0.3)\end{array}$ & 0.33 & $\begin{array}{c}0.3 \\
(0.3 / 0.4)\end{array}$ & 0.3 & $\begin{array}{c}0.7 \\
(0.7 / 0.7)\end{array}$ \\
\hline
\end{tabular}


Table 4-4

Groundwater Chemistry Data for ER-12-4 and Surrounding Area

(Page 2 of 2)

\begin{tabular}{|c|c|c|c|c|c|c|c|c|c|c|c|c|c|c|c|}
\hline & \multicolumn{2}{|c|}{ ER-12-4 } & \multirow{2}{*}{\begin{tabular}{|c|} 
ER-12-3 \\
$\begin{array}{c}\text { Composite } \\
7 / 06 / 05\end{array}$ \\
\end{tabular}} & \multirow{2}{*}{$\begin{array}{l}\text { ER-12-1 } \\
12 / 08 / 04\end{array}$} & \multirow{2}{*}{$\begin{array}{l}\text { TW-1 } \\
7 / 10 / 91\end{array}$} & \multirow{2}{*}{$\begin{array}{l}\text { U-12s } \\
7 / 13 / 93\end{array}$} & \multirow{2}{*}{$\begin{array}{l}\text { ER-12-2 } \\
4 / 01 / 03\end{array}$} & \multirow{2}{*}{$\begin{array}{c}\text { U12n.05 } \\
\begin{array}{c}7 / 01 / 84 \\
\text { to } 8 / 16 / 86\end{array}\end{array}$} & \multirow{2}{*}{$\begin{array}{l}\text { U12n.03 } \\
5 / 09 / 86\end{array}$} & \multirow{2}{*}{$\begin{array}{c}\text { U12t } \\
11 / 20 / 72\end{array}$} & \multirow{2}{*}{$\begin{array}{c}\text { UE-10j-1 } \\
3 / 17 / 97\end{array}$} & \multirow{2}{*}{\begin{tabular}{|c|} 
UE-10j-2 \\
$3 / 20 / 97$ \\
\end{tabular}} & \multirow{2}{*}{\begin{tabular}{|c|} 
UE-10j-3 \\
$3 / 24 / 97$ \\
\end{tabular}} & \multirow{2}{*}{$\begin{array}{l}\text { WW-2 } \\
2 / 08 / 05\end{array}$} & \multirow{2}{*}{$\begin{array}{c}\text { WW-8 } \\
11 / 04 / 97\end{array}$} \\
\hline & $\begin{array}{c}\text { Discrete } \\
\text { Bailer } \\
8 / 04 / 05\end{array}$ & $\begin{array}{l}\text { Composite } \\
8 / 15 / 05 \text { to } \\
4 / 25 / 06\end{array}$ & & & & & & & & & & & & & \\
\hline Iron (mg/L) & 0.35 & $\begin{array}{c}0.04 \\
(0.03 / 0.05)\end{array}$ & $\begin{array}{c}0.22 \\
(0.16 / 0.26)\end{array}$ & \begin{tabular}{c|}
3.41 \\
$(2.04 / 4.99)$
\end{tabular} & \begin{tabular}{c|}
0.15 \\
$(0.04 / 0.23)$
\end{tabular} & 0.2 & $\begin{array}{c}0.27 \\
(0.26 / 0.28)\end{array}$ & NM & NM & 0.07 & 0.88 & 0.09 & 0.09 & NM & 0.01 \\
\hline Lithium (mg/L) & 0.02 & $\begin{array}{c}0.014 \\
(0.012 / 0.017) \\
\end{array}$ & \begin{tabular}{c|}
0.025 \\
$(0.024 / 0.027)$ \\
\end{tabular} & \begin{tabular}{c|}
0.27 \\
$(0.26 / 0.28)$ \\
\end{tabular} & \begin{tabular}{|c|}
0.059 \\
$(0.04 / 0.13)$ \\
\end{tabular} & 0.13 & $\begin{array}{c}0.23 \\
(0.19 / 0.24) \\
\end{array}$ & 0.04 & 0.05 & 0.03 & 0.33 & 0.15 & 0.09 & NM & $\begin{array}{c}0.028 \\
(0.027 / 0.029) \\
\end{array}$ \\
\hline Manganese (mg/L) & 0.012 & \begin{tabular}{c|}
0.026 \\
$(0.013 / 0.039)$
\end{tabular} & \begin{tabular}{|c|}
0.028 \\
$(0.027 / 0.028)$
\end{tabular} & $\begin{array}{c}0.12 \\
(0.11 / 0.14)\end{array}$ & $<0.03^{b}$ & $<0.01$ & $\begin{array}{c}0.02 \\
(0.02 / 0.02)\end{array}$ & NM & NM & $<0.01$ & 0.08 & 0.10 & 0.07 & NM & $\begin{array}{c}0.0012 \\
(0.0011 / 0.0012)\end{array}$ \\
\hline Selenium (mg/L) & $<0.005$ & $<0.005$ & $<0.005$ & $<0.005$ & $<0.1^{\mathrm{b}}$ & $<0.007$ & $<0.005$ & NM & NM & NM & $<0.01$ & $<0.01$ & $<0.01$ & NM & $\begin{array}{c}0.0007 \\
(0.0007 / 0.0007)\end{array}$ \\
\hline Silicon dioxide (mg/L) & 14.8 & $\begin{array}{c}14.4 \\
(9.0 / 21.4)\end{array}$ & $\begin{array}{c}24 \\
(23.5 / 25)\end{array}$ & $\begin{array}{c}21.6 \\
(18.4 / 24)\end{array}$ & \begin{tabular}{c|}
14.4 \\
$(12.0 / 20.2)$ \\
\end{tabular} & 22.0 & $\begin{array}{c}21.6 \\
(14.8 / 25.5) \\
\end{array}$ & $\begin{array}{c}52 \\
(51 / 54) \\
\end{array}$ & $\begin{array}{c}46 \\
(44 / 48)\end{array}$ & 42 & \begin{tabular}{c|}
40.7 \\
$(38.7 / 42.8)$ \\
\end{tabular} & 36.4 & $\begin{array}{c}32 \\
(29.7 / 34) \\
\end{array}$ & 7.7 & 50 \\
\hline Strontium (mg/L) & 0.083 & $\begin{array}{c}0.054 \\
(0.050 / 0.058)\end{array}$ & \begin{tabular}{|c|}
0.104 \\
$(0.098 / 0.111)$
\end{tabular} & \begin{tabular}{c|}
0.21 \\
$(0.02 / 0.21)$
\end{tabular} & \begin{tabular}{c|}
0.02 \\
$(0.01 / 0.03)$ \\
\end{tabular} & 2.06 & $\begin{array}{c}0.33 \\
(0.32 / 0.34)\end{array}$ & NM & NM & $<0.01$ & 0.47 & 0.32 & 0.27 & NM & $\begin{array}{c}0.005 \\
(0.005 / 0.006)\end{array}$ \\
\hline Uranium $(\mu \mathrm{g} / \mathrm{L})$ & $<100$ & $\begin{array}{c}0.31 \\
(0.10 / 0.4)\end{array}$ & $\begin{array}{c}1.9 \\
(<50 / 2.0)\end{array}$ & \begin{tabular}{c|}
1.6 \\
$(<100 / 1.7)$
\end{tabular} & $<0.6^{\mathrm{b}}$ & ND & NM & NM & NM & NM & 5 & 3 & 3 & NM & $\begin{array}{c}0.37 \\
(0.35 / 0.39)\end{array}$ \\
\hline \multicolumn{16}{|c|}{ Environmental Isotopes and Tritium } \\
\hline$\delta^{13} \mathrm{C}(\%)$ & NM & $\begin{array}{c}-7.85 \\
(-8.1 /-7.6)\end{array}$ & $\begin{array}{c}-5.7 \\
(-6.0 /-5.4)\end{array}$ & \begin{tabular}{c|}
-10.8 \\
$(-10.8 /-10.7)$
\end{tabular} & -10.2 & NM & $\begin{array}{c}-5.6 \\
(-6.2 /-4.9)\end{array}$ & NM & NM & NM & $\begin{array}{c}-3.6 \\
(-4.6 /-2.7)\end{array}$ & $\begin{array}{c}-5.7 \\
(-6.4 /-5.1)\end{array}$ & $\begin{array}{c}-7.7 \\
(-7.9 /-7.4)\end{array}$ & NM & $\begin{array}{c}-12 \\
(-12 /-11)\end{array}$ \\
\hline${ }^{14} \mathrm{C}(\mathrm{pmc})$ & NM & 6.9 & 2.9 & 11.0 & 30 & 100 & 1.5 & NM & NM & NM & 7.5 & 11.4 & 12.6 & NM & 25 \\
\hline${ }^{36} \mathrm{C} / / \mathrm{Cl}$ & NM & $5.6 \mathrm{E}-13$ & $5.39 \mathrm{E}-13$ & $7.80 \mathrm{E}-13$ & $9.68 \mathrm{E}-13$ & $3.35 \mathrm{E}-13$ & $6.90 \mathrm{E}-13$ & NM & NM & NM & $2.41 \mathrm{E}-13$ & $3.91 \mathrm{E}-13$ & $4.45 \mathrm{E}-13$ & NM & NM \\
\hline$\delta \mathrm{D}(\%)$ & NM & $\begin{array}{c}-102 \\
(-103 /-100)\end{array}$ & $\begin{array}{c}-106 \\
(-106 /-106)\end{array}$ & \begin{tabular}{c|}
-94 \\
$(-94.5 /-94)$
\end{tabular} & $\begin{array}{c}-111 \\
(-112 /-111)\end{array}$ & -94 & $\begin{array}{c}-101 \\
(-101 /-101)\end{array}$ & $\begin{array}{c}-94.4 \\
(-97 /-90)\end{array}$ & \begin{tabular}{c|}
-97 \\
$(-101 /-90)$
\end{tabular} & NM & \begin{tabular}{c|}
-104 \\
$(-107 /-101)$
\end{tabular} & $\begin{array}{c}-102 \\
(-105 /-98)\end{array}$ & $\begin{array}{c}-100 \\
(-103 /-97)\end{array}$ & \begin{tabular}{|c|}
$-103^{\mathrm{a}}$ \\
$(-104 /-102)$
\end{tabular} & -103 \\
\hline$\delta^{18} \mathrm{O}(\%)$ & NM & $\begin{array}{c}-13.7 \\
(-13.7 /-13.7)\end{array}$ & $\begin{array}{c}-14.5 \\
(-14.5 /-14.5)\end{array}$ & \begin{tabular}{c|}
-12.6 \\
$(-12.6 /-12.6)$
\end{tabular} & $\begin{array}{c}-14.9 \\
(-15 /-14.8)\end{array}$ & -12.6 & $\begin{array}{c}-13.7 \\
(-13.8 /-13.5)\end{array}$ & $\begin{array}{c}-13.0 \\
(-13.4 /-11.9)\end{array}$ & \begin{tabular}{|c|}
-13.4 \\
$(-14.2 /-12.4)$
\end{tabular} & NM & $\begin{array}{c}-13.6 \\
(-13.6 /-13.5)\end{array}$ & $\begin{array}{c}-13.2 \\
(-13.2 /-13.1)\end{array}$ & $\begin{array}{c}-12.8 \\
(-12.9 /-12.8)\end{array}$ & \begin{tabular}{c|}
$-13.5^{\mathrm{a}}$ \\
$(-14.2 /-13.0)$
\end{tabular} & -13.5 \\
\hline${ }^{87} \mathrm{~S} /{ }^{86} \mathrm{Sr}$ & NM & $\begin{array}{c}0.71068 \\
(0.71041 / \\
0.71096)\end{array}$ & $\begin{array}{c}0.71045 \\
(0.71034 / \\
0.71055)\end{array}$ & $\begin{array}{c}0.71234 \\
(0.71234 / \\
0.71235)\end{array}$ & 0.70893 & 0.70555 & $\begin{array}{c}0.71662 \\
(0.71659 / \\
0.71664)\end{array}$ & NM & NM & NM & 0.71464 & 0.71352 & 0.71261 & NM & 0.71025 \\
\hline${ }^{234} \mathrm{U} / 234 \mathrm{U}$, Activity & NM & $\begin{array}{c}2.0 \\
(1.9 / 2.1)\end{array}$ & $\begin{array}{c}2.1 \\
(2.1 / 2.2)\end{array}$ & $\begin{array}{c}5.3 \\
(1.6 / 7.2)\end{array}$ & NM & NM & $\begin{array}{c}5.3 \\
(3.3 / 6.3)\end{array}$ & NM & NM & NM & 5.05 & 4.98 & 4.96 & NM & 2.9 \\
\hline Tritium (pCi/L) & $<360$ & $\begin{array}{c}89.7 \\
(<500 / 89.7)\end{array}$ & $\begin{array}{c}0.5 \\
(<350 / 0.5)\end{array}$ & $\begin{array}{c}3.2 \\
(<360 / 3.2)\end{array}$ & $\begin{array}{c}57 \\
(54 / 60)\end{array}$ & NM & $\begin{array}{c}4.3 \\
(<500 / 4.3)\end{array}$ & NM & NM & NM & 38.5 & NM & 61.9 & $10^{\mathrm{a}}$ & NM \\
\hline
\end{tabular}

aThe $\delta D$ and $\delta^{18} O$ values for WW-2 are an average from samples collected on 6/02/82, 9/11/89, and 4/16/90.

belected parameters for TW-1 are from a sample collected on 8/13/92 by LLNL.

Note: A single value is reported when multiple measurements were not performed for a specific parameter. When multiple measurements were made for a specific parameter, the average is reported along with the minimum and maximum value (in parentheses). Values reported as below the detection limit were not included when calculating the average. This is so that concentrations are not biased high due to measurements made by laboratories with large relative detections limits. This is particularly important for reporting tritium activities where detection limits often vary by two to three orders of magnitude depending on the analytical procedure. 
A brief description of the well and tunnel seep samples included in this comparison (see Figure 1-2) is provided below.

- Well ER-12-1 is located in the Rainier Mesa/Shoshone Mountain CAU. Groundwater samples are collected from the uppermost formation access zone of this well that produces groundwater from a carbonate aquifer section (related to the LCA3 HSU) within the upper clastic confining unit (UCCU) HSU.

- Well U-12s produces groundwater from the Mesozoic granite confining unit (MGCU). Only one sample has been collected from this well, and some of the analytical results are somewhat anomalous (for instance, the ${ }^{14} \mathrm{C}$ was reported to be 100 percent modern).

- Well TW-1 produces water from the Belted Range aquifer (BRA). Although samples were collected from different depths within this well $(1,470,1,510,1,553,1,740$, and 1,930 ft bgs), similar chemistry is observed. This is apparent from the narrow ranges in concentrations shown in Table 4-4. For this reason, the average groundwater composition from all depths was used for the evaluation.

- U12n.05 and U12n.03 samples were collected from the N-Tunnel. These data are described in detail by Russell (1987). Several samples were collected between July 1984 and August 1986. The mean of all samples, along with the range of values, are reported in Table 4-4. These samples represent perched waters of the volcanic confining unit.

- U12t samples were collected from the main drift of the T-Tunnel. Samples were collected by the USGS in 1972 and analyzed for physical parameters, major constituents, and only a few minor constituents. No environmental isotope data are available. These samples represent perched waters of the volcanic confining unit.

- Well ER-12-2 is located in Yucca Flat and is completed in the UCCU. Measured ${ }^{14} \mathrm{C},{ }^{36} \mathrm{Cl} / \mathrm{Cl}$, ${ }^{87} \mathrm{Sr} /{ }^{86} \mathrm{Sr}$, and ${ }^{3} \mathrm{He} /{ }^{4} \mathrm{He}$ of these groundwaters are consistent with a groundwater residence time between 10,000 and 60,000 years; however, a component of local recharge could not be ruled out based on the measured $\delta \mathrm{D}$ and $\delta^{18} \mathrm{O}$ values (LLNL, 2003).

- Well UE-10j is located in northern Yucca Flat and is constructed such that three zones within the well are sampled. Although all three zones are completed in the LCA, a recent geochemical study conducted for the Yucca Flat/Climax Mine CAU (SNJV, 2006a) indicated that the shallowest zone (UE-10j-3) was dominated by a local recharge component (70 to 87 percent) mixed with a much smaller percentage of groundwater inflow through the LCA that was represented by groundwater of the deepest zone of the same well (UE-10j-1).

- Well WW-2 is located in Yucca Flat southwest of UE-10j. Geochemical models presented in SNJV (2006a) suggested that the groundwaters of WW-2 can be derived from a mixture of groundwater from TW-1, UE-10j-3, and Oak Spring, and that groundwater at WW-2 is primarily derived from mixing of volcanic and perched water sources in northern Yucca Flat. 
The geochemical models indicated that only 4 percent or less of the groundwater at $\mathrm{WW}-2$ is derived by inflow through the LCA.

- Well WW-8 produces water from the BRA HSU. Samples were collected by multiple organizations (DRI, LLNL, and USGS) on November 4, 1997, to obtain a full suite of analytical parameters to support a geochemical evaluation of flow paths within Pahute Mesa Oasis Valley (Rose et al., 2002). The mean values for these samples were therefore used for the evaluation described herein.

The data in Table 4-4 were used to construct the trilinear diagram shown in Figure 4-3. Trilinear diagrams are used to identify trends or similarities in groundwater chemistry based on the relative abundance of major ions in groundwater samples. The concentrations along the axes are expressed in percent milliequivalents per liter. The two triangles in the lower left and right corners represent the major cations and anions, respectively. The diamond-shaped field in the center combines the information from the adjacent cation and anion triangles, and is used to illustrate similarities in groundwater chemistry (i.e., water types) and any relationships that may exist between different water types.

All samples from ER-12-4 are quite similar to each other with respect to the trilinear diagram (Figure 4-3). This includes samples analyzed by the different labs and also samples collected during the three different sampling dates. These samples represent a borderline $\mathrm{Na}-\mathrm{HCO}_{3} / \mathrm{Ca}-\mathrm{Mg}-\mathrm{Na}-\mathrm{HCO}_{3}$ water type, suggesting that the groundwater of ER-12-4 is largely comprised of groundwater of a volcanic aquifer. The groundwater samples are quite distinct from the Ca-Mg- $\mathrm{HCO}_{3}$ type groundwater of UE-10j; this water type is representative of waters of a carbonate aquifer. Well ER-12-4 groundwaters are chemically distinct from those of ER-12-1 and are more similar to those of WW-2 and WW-8. As previously mentioned, groundwaters of WW-2 are thought to be a mixture of volcanic and perched water sources in northern Yucca Flat with little contribution from inflow through the LCA. Groundwaters of WW-8 are from a volcanic aquifer.

Figure 4-4 shows the $\delta \mathrm{D}$ and $\delta^{18} \mathrm{O}$ composition of groundwater for ER-12-4 and selected wells and tunnel seeps in its vicinity. The primary HSU sampled for each location is also identified in Figure 4-4. The results of both analyses of the ER-12-4 sample are presented. The global meteoric water line (Craig, 1961) and the local meteoric water line (Ingraham et al., 1990) are also shown in Figure 4-4. It is clear from Figure 4-4 that a high variability of $\delta^{18} \mathrm{O}$ and $\delta \mathrm{D}$ values is observed for groundwaters of the LCA3 in this region. This suggests a variety of sources of these groundwaters. 


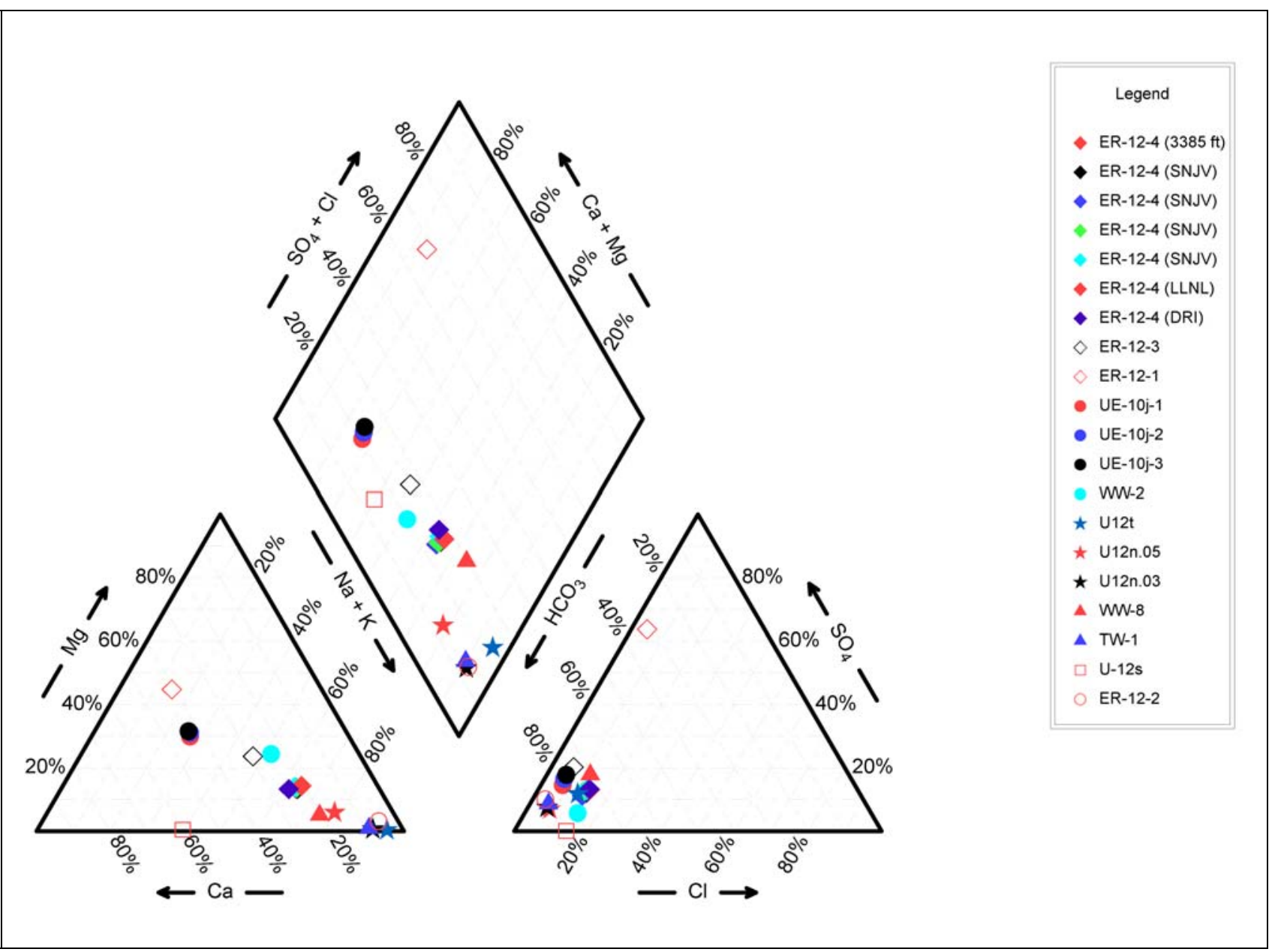

Figure 4-3

Piper Diagram Showing Relative Major Ion Percentages for Groundwater from ER-12-4 and Vicinity

Note: LCA3 samples are represented using diamonds, LCA samples are represented using solid circles, tunnel samples are represented using stars, BRA samples are represented using triangles, MGCU samples are represented using an open square, and UCCU samples are represented using an open circle.

The $\delta^{18} \mathrm{O}$ and $\delta \mathrm{D}$ values for ER-12-4 are similar to those of the carbonate aquifers of Yucca Flat but are also similar to those of the BRA represented by WW-8. Careful evaluation of flow paths, water-rock interaction, and groundwater mixing models will be necessary to further evaluate the source of these groundwaters.

\subsection{Restoration of Natural Groundwater Quality}

A primary purpose for well development is to restore the natural groundwater quality of the completion interval so that groundwater samples would accurately represent the water quality of the 


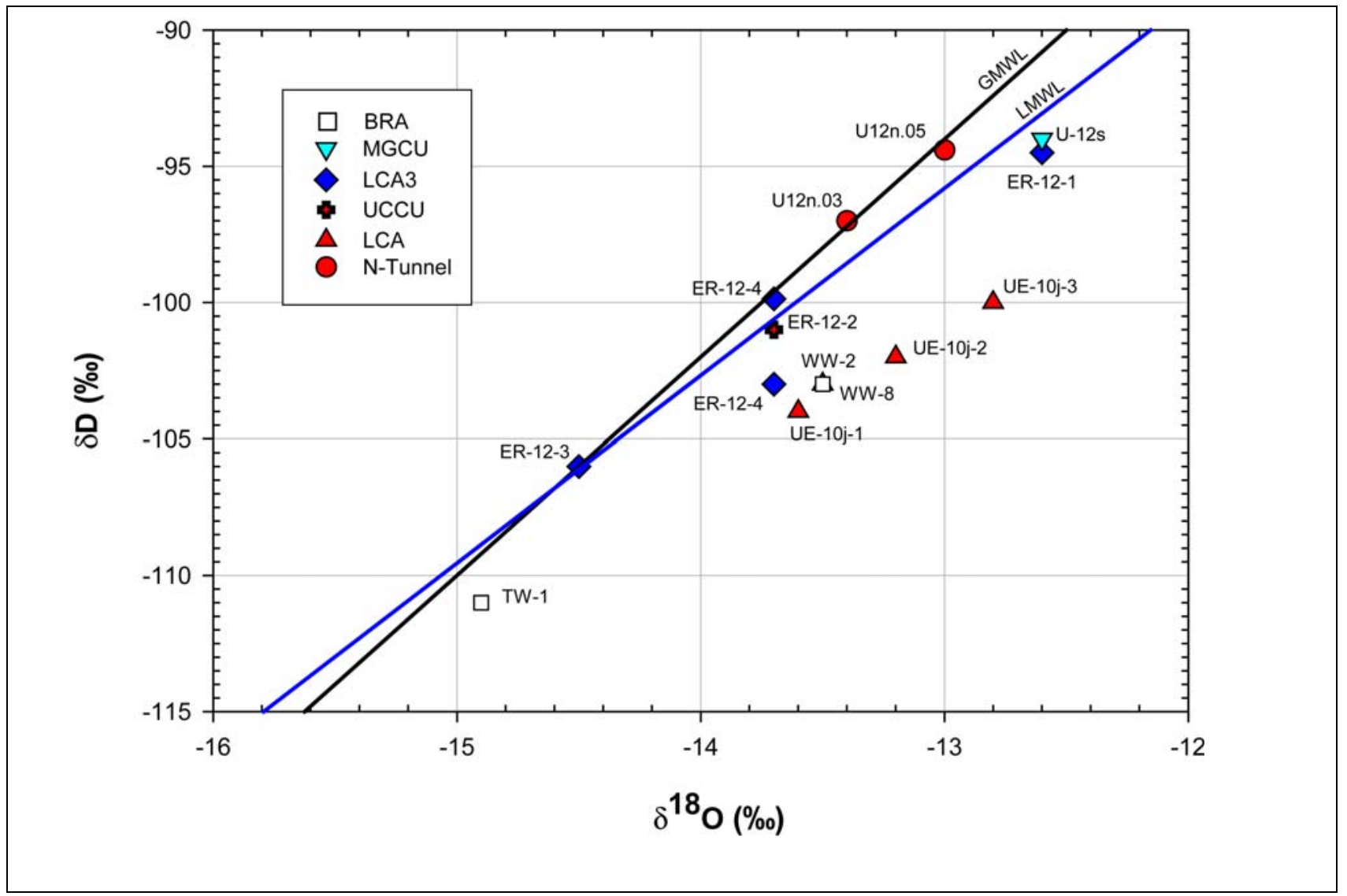

Figure 4-4

Stable Isotope Composition for ER-12-4 and Vicinity

producing formation. During drilling operations for ER-12-4, the makeup water was tagged with a lithium bromide $(\mathrm{LiBr})$ tracer to help determine groundwater influx in the borehole and the respective water production rate during drilling, and for use in evaluation of progress and completeness of development. The makeup water was tagged with a $\mathrm{LiBr}$ concentration of approximately 10 to $50+$ $\mathrm{mg} / \mathrm{L}$. This relatively high concentration of bromide ions $\left(\mathrm{Br}^{-}\right)$injected into the wellbore provides a potential means to ascertain the effectiveness of the well development. Table 4-2 shows that the dissolved concentration of $\mathrm{Br}^{-}$was less than $0.5 \mathrm{mg} / \mathrm{L}$ for both the depth-discrete bailer and the composite groundwater samples. This value is substantially lower than the concentration of $\mathrm{Br}^{-}$used during drilling, and likely indicates that the well was sufficiently developed to restore groundwater quality back to its natural condition. This conclusion pertains only to the formation(s) producing water during pumping. 


\subsection{Source Formation(s) of Groundwater Samples}

The production distribution of water during pumping was discussed in Section 3.4, and the flow in the well under ambient conditions was discussed in Section 2.2.3. During pumping, groundwater appears to be produced from fractures around 1,025 $\mathrm{m}$ bgs (3,360 ft bgs) and above in the LCA3, indicating that the LCA3 is the source of produced water. The static water level in the well is below the top of the LCA, indicating that the carbonate aquifer formation is not continuously saturated up to the overlying volcanic formation. This would seem to preclude any other direct source of water from the overlying volcanic formation, either through the wellbore or by saturated vertical flow to the LCA. However, there is some suggestion that the higher "perched" head in the overlying volcanic formation is possibly connected to the producing fracture, perhaps through high-angle fractures, because of the apparent higher head at about 1,025 m bgs causing flow from this depth both upwards and downwards. The apparent volcanic component for groundwater produced from the LCA3 during pumping, apparently coming from the formation at a depth of about 1,025 m bgs, also suggests that there is a pathway for contribution to produced water from the overlying volcanic formation.

\subsection{Representativeness of Water Chemistry Results}

Although the completion interval for this well is within the LCA3, a general agreement between all chemical indicators (major ions, stable isotopes, ${ }^{36} \mathrm{Cl} / \mathrm{Cl}$, and ${ }^{87} \mathrm{Sr} /{ }^{86} \mathrm{Sr}$ ) suggests that the groundwater is not typical of the groundwater of a carbonate aquifer. The ER-12-4 samples instead appear to be a mixture of groundwater of a carbonate aquifer and a volcanic rock aquifer. Though there is a low likelihood, it should be noted that the presence of makeup water from WW-8 may be the cause of the volcanic rock aquifer signature of the ER-12-4 groundwaters. Again, the absence of $\mathrm{Br}$ in the groundwaters indicates that this is not the case.

\subsection{Use of ER-12-4 for Future Monitoring}

Well ER-12-4 is located within 1 mile of six nuclear tests, all of which were detonated above the water table. The local direction of groundwater flow is not known, and the productive intervals in this well are a considerable depth below the HSU directly impacted by nuclear testing. The presence of tritium in this well suggests that further monitoring is necessary to determine the source. If the 
source of tritium in this well is in fact nuclear testing, this well is a good choice for monitoring radionuclide transport within this area.

Sampling groundwater from the ER-12-4 piezometer may be more appropriate for monitoring radionuclide transport from the tests in Rainier Mesa. This is provided that the piezometer could be adequately purged, ensuring that formation water of the volcanic aquifer and confining units are sampled. 


\subsection{Review of the Testing Program and analysis}

This section contains comments on the interpretation and analysis of the testing data, and related aspects of well design, test design, and test implementation. Recommendations for changes are provided.

Review and analysis of the testing program found a number of problems that affected data quality, and hindered analysis of the data and determination of basic hydrologic characterization data.

- Representative head (water levels) was established for the two completions, but there are indications of substantial natural vertical gradient in the formation(s). The available information does not support determination of the vertical gradient; consequently, the appropriate use of the head values is uncertain.

- The flow and temperature logs reflect the alternating slotted and unslotted casing, which obscures the profile of production distribution from the formation.

- Flow log data appear to have significantly been affected by well construction. The data are dominated by patterns in the recorded impeller response related to the screens that do not appear to reflect actual production variation, making determination of representative flow profiles is difficult. It is believed that the lack of gravel pack in the annulus outside the well completion is primarily responsible, allowing large eddies to develop around the logging tool.

- The analysis of hydraulic testing included additional uncertainty due to the lack of pre-test monitoring for both tests' datasets. This affected the establishment of baseline conditions for the test analysis, including the equilibrium condition and background water-level trends.

- Analysis of the FY 2006 test dataset was affected by the effect on the recovery data due to the lack of a check valve in the pump column and by the lack of a continuous production-rate record. This pumping episode was not intended as a hydraulic test, and the pumping was not conducted according to standards for testing. However, this pumping episode constituted a better constant-rate test dataset than was available from the original testing program. The analysis was able to determine representative hydraulic property values. 


\subsection{Comments on Well Design}

Several features of the well design resulted in problems with testing data collection: 1) the arrangement of alternating intervals of unslotted and slotted casing, 2) the lack of filter pack in the annulus of the completion, and 3) the lack of discrete, isolated intervals in the completion.

The flow and temperature logs reflect a flow pattern that alternates between inflow and outflow through slotted intervals, and flow between slotted intervals in unslotted intervals. This makes it difficult to determine the actual distribution of production from the formation. The intervals of slotted casing are not necessarily coincident with the fracturing and/or production from the formation, and groundwater production occurs both behind slotted casing and behind unslotted casing, However, changes in production can only be observed in the slotted intervals.

The flow logs show large changes associated with the top and bottom of the slotted intervals that are not believed to reflect actual production changes in the well. The interpretation is that the lack of filter pack in the annulus allows circulation from inside the completion casing to the annulus driven by trolling of the logging tool. The effect on the flow logs through the slotted intervals makes them difficult and uncertain to interpret.

The lack of discrete completion intervals separated by annular seals precludes measurement of head differences for the different fracturing intervals and from the top to the bottom of the completion. Inclusion of periodic annular seals that would allow isolation of discrete intervals would allow discrete head measurements. In formations where there is apparently a large vertical gradient, this information is important as well as needed to determine accurate parameter values from the testing.

Future well designs should consider installation of continuous slotted casing to provide continuous access to the formation. This design would allow the flow pattern for the formation to be observed directly rather than having to infer the pattern. Inclusion of filter material in the annulus generally appears to restrict vertical circulation in the annulus such that flow observed in the well casing can be more simply interpreted as a reflection of flow from or into the formation. Placement of periodic annular seals would allow isolation of different depth intervals for hydraulic head measurements so that the natural vertical gradient could be determined. 


\subsection{Comments on the Well Testing Program}

Several aspects of the records collected during the testing program were problematic, as described in the following sections. While the testing program was conducted according to the testing plan, the schedule for the testing program did not provide sufficient time to collect optimal records because the well was slow to recover from stresses. Future testing program schedules should be determined to the extent possible to provide improved information according to the recommendations provided below. The cited below deficiencies may not be considered serious for this testing program due to the nature of the formation tested (low permeability) and the fact that analysis results for K were obtained that may be considered fairly representative. However, the hydrogeology of the formation is not well characterized in many ways, and significant questions are unanswered.

\subsubsection{Pre-Test and Post-Test Monitoring Records}

The processing of the water-level monitoring record to determine the drawdown response would be greatly improved with the collection of sufficiently long pre-test and recovery records to support accurate characterization of background trends. The scheduled predevelopment monitoring for this well and the preconstant-rate-test monitoring were not long enough to allow the well to equilibrate after drilling/construction or to recover from development, and to provide a sufficient record to determine any background water-level trend. This situation overlaps with the discussion in the next subsection. In general, the pre-test record should be at least equal to the length of the test after equilibration following drilling and construction. The post-test record should continue until the well has fully recovered and temperature has equilibrated. The latter situation can be determined by a comprehensive and detailed look at the monitoring records to evaluate the situation with respect to background trends. Schedules need to be flexible enough to accommodate slow equilibration.

Also, the BE analysis was hampered by the short records collected and by the fact that these records were collected when the well was still equilibrating from previous pumping. The lack of a record incorporating the response to a significant barometric pressure change precluded determining $\mathrm{BE}$ accurately. 


\subsubsection{Background Well Monitoring Record}

A substantial improvement in the processing of the drawdown monitoring record to determine the actual drawdown response can be provided by the use of a contemporaneous record from a background well to remove background water-level trends, earth tides, and other non-specific noise in the testing drawdown record. However, the background record recorded in nearby ER-12-1 during testing of this well did not serve the purpose because the record contained a trend that could not be verified as appropriate for use at ER-12-4. Monitoring at ER-12-3 may have provided a suitable record, but post-testing monitoring at this well was discontinued before the period needed. Selection of an appropriate background well for monitoring during testing should be considered with particular attention to location, completion, and representativeness of the formation response for application to the well to be tested. The record should start well before testing activities begin and extend past the completion of recovery monitoring for the test(s).

\subsubsection{Starting Testing from Non-Equilibrium Condition}

This well did not recover head quickly from any of the production stresses, including the initial drilling, and the testing program was begun before recovery from previous development was complete. This situation requires that the previous stress history be included in the analyses, which significantly complicated the overall analysis and introduced additional uncertainty. The FY 2006 testing was started from assumed equilibrium. However, the lack of any pre-test record makes this conjectural and precludes determination of any background water-level trend.

\subsubsection{Recovery Monitoring after the FY 2005 Testing}

Following the pumping portion of the FY 2005 testing, recovery monitoring was not continued until equilibration was achieved. Consequently, analysis of the recovery curve was not complete, the equilibrium head was not determined, and any background water-level trend was not determined.

\subsubsection{Lack of Check Valve during FY 2006 Pumping}

The lack of a check valve in the production tubing during the FY 2006 pumping affected the early time drawdown and recovery response such that the periods of the effect could not be matched to theoretical models. Evaluation of the derivative of the drawdown during this period is necessary to 
ascertain the correct conceptual model for the analysis, and the response during these time periods can be important in determining the best parameter fit.

\subsection{Comments on Water Quality Analyses}

The discrete-bailer water samples were not distributed to the DRI and LLNL labs for analysis. Analysis of these samples for environmental isotopes would be a valuable contribution to the geochemical data and should be considered in the future when such samples are taken.

\subsection{Use of ER-12-4 for Monitoring}

The ER-12-4 well completion is connected to the formation and provides water-level monitoring capability for the LCA3. However, as discussed in Section 3.4.2, there is an indication that there is a substantial vertical gradient within the LCA3, and the head at different depth intervals cannot be determined independently. The measured head is a transmissivity-weighted composite of the heads for the three intervals and must be interpreted in this context. The ER-12-4 piezometer provides water-level-monitoring capability for the volcanic formation above the LCA3.

The depth interval from which groundwater is produced with the installed pump for water quality determination may be identified from the temperature log, and appears to be very limited. This well provides suitable monitoring capability for LCA3 water quality in this location, limited to the specific depth interval, as well as for monitoring water-level trends in the LCA3. There is no evidence that the formation in the well completion is not representative of the LCA3 in this area, and that the groundwater quality of the samples is not representative.

\subsection{Summary}

This document presents the analysis of data for ER-12-4. The water levels measured during the testing program served to define the formation pressure used for analysis of the constant-rate test, and are indicative of a stable, representative head. The hydraulic test analysis provides an interpretation of the $\mathrm{T}$ of the well completion interval for the LCA3. However, an average value for K over the completion interval of the LCA3 is left for the user to determine the particular requirements for use of the $\mathrm{K}$ value due to the complicated production situation in the well. Values of $\mathrm{K}$ representative of different conceptual aquifer intervals are provided. 


\subsection{REFERENCES}

ASME, see American Society of Mechanical Engineers.

American Society of Mechanical Engineers. 1990. Quality Assurance Requirements of Computer Software for Nuclear Facility Applications, ASME NQA-2a-1990 addenda, Part 2.7. New York, NY.

Bredehoeft, J.D., and S.S. Papadopulos. 1980. "A Method for Determining the Hydraulic Properties of Tight Formations.” In Water Resources Research, v. 16(1): 233-238.

Cooper, H.H., Jr., J.D. Bredehoeft, and S.S. Papadopulos. 1967. "Response of a Finite-Diameter Well to an Instantaneous Charge of Water.” In Water Resources Research, v. 3(1): 263-269.

Craig, H. 1961. “Isotopic Variations in Meteoric Waters.” In Science, v. 133: 1702-1703. Washington, DC: American Association for the Advancement of Science.

DOE/NV, see U.S. Department of Energy, Nevada Operations Office.

Fabryka-Martin, J., S.J. Wightman, W.J. Murphy, M.P. Wickham, M.W. Caffee, G.J. Nimz, J.R. Southon, and P. Sharma. 1993. Distribution of Chlorine-36 in the Unsaturated Zone at Yucca Mountain: An Indicator of Fast Transport Paths. Paper presented at FOCUS '93 Site Characterization and Model Validation. Las Vegas, NV.

Horne, R.N. 1995. Modern Well Test Analysis. Palo Alto, CA: Petroway, Inc.

Ingraham, N.L., R.L. Jacobson, B.F. Lyles, and J.W. Hess. 1990. Stable Isotopic Study of Precipitation and Spring Discharge on the Nevada Test Site, Publication No. 45078; DOE/NV/10845-03. Las Vegas, NV: Desert Research Institute.

LLNL, see Lawrence Livermore National Laboratory.

Langmuir, D. 1997. Aqueous Environmental Geochemistry. Prentice-Hall, Inc., New Jersey. 600 p.

Lawrence Livermore National Laboratory. 2003. Letter Report to Robert Bangerter: "Isotopic Analyses: Environmental Monitoring Well ER-12-2,” 28 September.

Lawrence Livermore National Laboratory. 2006. Letter Report to Bill Wilborn: “Isotopic Analyses: Environmental Monitoring Well ER-12-4,” 10 March. 
Leavitt, A. 2005. Formation Image Interpretation Report, Bechtel Nevada, Well: ER-12-3, Nevada Test Site, Nye County, Nevada.

Lohman, S.W. 1972. Ground-Water Hydraulics, Professional Paper 708. U.S. Geological Survey.

NNSA/NSO, see U.S. Department of Energy, National Nuclear Security Administration Nevada Site Office.

Oberlander, P.L., and C.E. Russell. 2005. Borehole Flow and Horizontal Hydraulic Conductivity with Depth at Well ER-12-3, DOE/NV13609-LTR2005-00228. Las Vegas, NV.

Pickens, J.F., G.E. Grisak, J.D. Avis, D.W. Belanger, and M. Thury. 1987. “Analysis and Interpretation of Borehole Hydraulic Tests in Deep Boreholes: Principles, Model Development, and Applications.” In Water Resource Research, v. 23(7): 1341-1375. Washington, DC: American Geophysical Union.

Roberts, R.M., R.L. Beauheim, and P.S. Domski. 1999. Hydraulic Testing of Salado Formation Evaporites at the Waste Isolation Pilot Plant Site: Final Report, SAND98-2537. Albuquerque, NM: Sandia National Laboratories.

Rose, T.P., F.C. Benedict, Jr., J.M. Thomas, W.S. Sicke, R.L. Hershey, J.B. Paces, I.M. Farnham, and Z.E. Peterman. 2002. Written communication. Subject: Geochemical Data Analysis and Interpretation of the Pahute Mesa-Oasis Valley Groundwater Flow System, Nye County, Nevada. Livermore, CA: Lawrence Livermore National Laboratory. Reno, NV: Desert Research Institute and HSI GeoTrans. Denver, CO: U.S. Geological Survey. Las Vegas, NV: Harry Reid Center for Environmental Studies, University of Nevada.

Russell, C.E. 1987. Hydrogeologic Investigations of Flow in Fractured Tuffs, Rainier Mesa, Nevada Test Site. Masters Thesis. Las Vegas, NV: Department of Geoscience, University of Nevada Las Vegas.

SNJV, see Stoller-Navarro Joint Venture.

Stoller-Navarro Joint Venture. 2005a. Geochem05.mdb and a User's Guide to the Comprehensive Water Quality Database for Groundwater in the Vicinity of the Nevada Test Site, S-N/99205--059. Las Vegas, NV.

Stoller-Navarro Joint Venture. 2005b. Rainier Mesa-Shoshone Mountain Hydrolgeologic Investigation Wells Drilling and Completion Criteria, S-N/99205--038. Las Vegas, NV.

Stoller-Navarro Joint Venture. 2005c. Written communication. Subject: Rainier Mesa ER-12-4 Well Data Report. Las Vegas, NV. 
Stoller-Navarro Joint Venture. 2006a. Geochemical and Isotopic Evaluation of Groundwater Movement in Corrective Action Unit 97: Yucca Flat/Climax Mine, Nevada Test Site, Nevada, Rev. 0, S-N/99205--070. Las Vegas, NV.

Stoller-Navarro Joint Venture. 2006b. Written communication. Subject: Rainier Mesa Well ER-12-4 Data Report for Well Development and Hydraulic Testing. Las Vegas, NV.

Stoller-Navarro Joint Venture. 2006c. Written communication. Subject: Well ER-12-4 Preliminary Data Report for Submersible Pump Installation and Groundwater Sampling. Las Vegas, NV.

Surano, K.A., G.B. Hudson, R.A. Failor, J.M. Sims, R.C. Holland, S.C. MacLean, and J.C. Garrison. 1992. "Helium-3 Mass Spectrometry for Low-Level Tritium Analysis of Environmental Samples.” In Journal of Radioanalytical Nuclear Chemistry Articles, v. 161:443-453.

Theis, C.V. 1935. "The Relation Between the Lowering of the Piezometric Surface and the Rate and Duration of Discharge of a Well Using Groundwater Storage.” In Trans Amer. Geophys. Union, v. 2: 519-524.

USGS/DOE, see U.S. Geological Survey and U.S. Department of Energy.

U.S. Department of Energy, Nevada Operations Office. 2000. United States Nuclear Tests, July 1945 through September 1992, DOE/NV--209, Rev. 15. Las Vegas, NV.

U.S. Department of Energy, National Nuclear Security Administration Nevada Site Office. 2006. Completion Report for Well ER-12-4 Corrective Action Unit 99: Rainier Mesa - Shoshone Mountain, DOE/NV--1208. Las Vegas, NV.

U.S. Geological Survey and U.S. Department of Energy. 2006. Download of ER-12-4 main and ER-12-4 piezometer water-level monitoring data and graphs. As accessed at http://nevada.usgs.gov/doe_nv/sitepage_temp.cfm?site_id=371311116105902 (ER-12-4 main) and http://nevada.usgs.gov/doe_nv/sitepage_temp.cfm?site_id=371311116105901 (ER-12-4 piezometer) on 3 July. 


\section{Appendix A}

EMI Logs Containing Deviation Information for Well ER-12-4 


\section{A.1.0 Wellbore Deviation Surveys}

A specific wellbore deviation survey has not been run in this well; however, the EMI logs contain some information on deviation. The EMI logs include a drift-angle measurement at each depth station for the depth range of the log. These logs start at a depth of 2,200 ft bgs and continue to TD. Consequently, there is no information on borehole deviation above 2,200 ft bgs. The log indicates low deviation, <3 degrees from vertical, from 2,200 to 3,000 ft bgs, and steadily increasing deviation to about 11 degrees at TD. This represents substantial deviation at TD, and the correction for true vertical depth and bottom-hole location at TD would be significant. At the static water level, about $2,570 \mathrm{ft}$ bgs measured depth, the deviation is $<3$ degrees. A correction for true vertical depth from 2,200 ft bgs to 2,570 ft, based on the deviation measurements in the file CALI6_3_EMI.las, is about $0.26 \mathrm{ft}$, which is less than the criteria of $0.5 \mathrm{ft}$ used by the USGS for inclusion in the reported depth-to-water.

Table A.1-1 shows electronic files of one EMI log, which has been included on the CD in text format.

Table A.1-1

EMI Log with Borehole Deviation Information

\begin{tabular}{|c|c|c|}
\hline File Name & $\begin{array}{c}\text { Depth Range } \\
\text { (ft bgs) }\end{array}$ & $\begin{array}{c}\text { Azimuth Range } \\
\text { (Degrees from North) }\end{array}$ \\
\hline \hline CALI6_3_EMI.las & 2,400 to 3,727 & 150 to 336 \\
\hline
\end{tabular}




\section{Appendix B}

Data for Well ER-12-4 FY 2006 Sampling Program 


\section{B.1.0 Datalogger Data}

The file ER-12-4_FY_2006.xls on the CD contains datalogger data from the FY 2006 ER-12-4 Sampling Program during the purging and recovery. Only the main well was monitored. The file contains the Julian Date, PXD pressure (in psi), PXD temperature (in ${ }^{\circ} \mathrm{C}$ ), barometric pressure (in millibars), and the flowmeter rate (in gpm).

\section{B.2.0 Continuous Multiprobe Logging Data}

The file ER-12-4 Probe Log.xls on the CD contains continuous logging data from the Los Alamos National Laboratory multiprobe. The results include water temperature, specific conductance, dissolved oxygen concentration, $\mathrm{pH}$, and oxidation/reduction potential obtained from a flow-through cell during the April 25, 2006, sampling event. 
CD

Electric Micro-Imager Logs Containing Deviation Information and LANL Continuous Multiprobe Logging Data for Well ER-12-4 


\section{DISTRIBUTION}

Bill R. Wilborn

Environmental Restoration Project

U.S. Department of Energy

National Nuclear Security Administration

Nevada Site Office

P.O. Box 98518, MS/505

Las Vegas, NV 89193-8518

Alicia Tauber

Environmental Management Records

U.S. Department of Energy

National Nuclear Security Administration

Nevada Site Office

P.O. Box 98518, MS/505

Las Vegas, NV 89193-8518

U.S. Department of Energy

National Nuclear Security Administration

Nevada Site Office

Technical Library

P.O. Box 98518, M/S 505

Las Vegas, NV 89193-8518

U.S. Department of Energy

Office of Scientific and Technical Information

P.O. Box 62

Oak Ridge, TN 37831-0062

Southern Nevada Public Reading Facility

c/o Nuclear Testing Archive

P.O. Box 98521, M/S 400

Las Vegas, NV 89193-8521

Manager, Northern Nevada FFACO

Public Reading Facility

c/o Nevada State Library \& Archives

100 N Stewart Street

Carson City, NV 89701-4285
$2 \mathrm{HC} / 2 \mathrm{CD}$

$1 \mathrm{HC} / 1 \mathrm{CD}$
$1 \mathrm{CD}$

$2 \mathrm{HC} / 2 \mathrm{CD}$

$1 \mathrm{HC} / 1 \mathrm{CD}$ 
Naomi Becker

$1 \mathrm{CD}$

Los Alamos National Laboratory, M/S F665

Bikini Atoll Rd., SM30

Los Alamos, NM 87545

P. W. Reimus

$1 \mathrm{CD}$

Los Alamos National Laboratory, M/S J534

Bikini Atoll Rd., SM30

Los Alamos, NM 87545

Gayle Pawloski

$1 \mathrm{CD}$

Lawrence Livermore National Laboratory

7000 East Avenue, L-221

Livermore, CA 94550-9234

Mavrik Zavarin

$1 \mathrm{CD}$

Lawrence Livermore National Laboratory

7000 East Avenue, L-221

Livermore, CA 94550-9234

R. M. Maxwell

$1 \mathrm{CD}$

Lawrence Livermore National Laboratory

7000 East Avenue, L-208

Livermore, CA 94550-9234

Bonnie Thompson

$1 \mathrm{CD}$

U. S. Geological Survey

160 North Stephanie Street

Henderson, NV 89074

R. P. Graves

$1 \mathrm{CD}$

U. S. Geological Survey

160 North Stephanie Street

Henderson, NV 89074

Chuck E. Russell

$1 \mathrm{CD}$

Desert Research Institute

755 E. Flamingo

Las Vegas, NV 89119

Ken Ortego

$1 \mathrm{CD}$

National Security Technologies

P.O. Box 98521, M/S NLV 082

Las Vegas, NV 89193-8521 
Sig Drellack

$1 \mathrm{CD}$

National Security Technologies

P. O. Box 98521, M/S NLV 082

Las Vegas, NV 89193-8521

John P. McCord

$1 \mathrm{CD}$

Stoller-Navarro Joint Venture

7710 W. Cheyenne, Bldg. 3

Las Vegas, NV 89129

Greg Ruskauff

$1 \mathrm{CD}$

Stoller-Navarro Joint Venture

7710 W. Cheyenne, Bldg. 3

Las Vegas, NV 89129

Jeff Wurtz

$1 \mathrm{CD}$

Stoller-Navarro Joint Venture

7710 W. Cheyenne, Bldg. 3

Las Vegas, NV 89129

Irene Farnham

$1 \mathrm{CD}$

Stoller-Navarro Joint Venture

7710 W. Cheyenne, Bldg. 3

Las Vegas, NV 89129

Bill Fryer

$1 \mathrm{CD}$

Stoller-Navarro Joint Venture

990 S. Public, Suite A

Lafayette, CO 80026

Stoller-Navarro Joint Venture

$1 \mathrm{HC} / 1 \mathrm{CD}$

Central Files

7710 W. Cheyenne, Bldg. 3

Las Vegas, NV 89129

Public Reading Facility Coordinator

$1 \mathrm{HC} / 1 \mathrm{CD}$

Stoller-Navarro Joint Venture

7710 W. Cheyenne, Bldg. 3

Las Vegas, NV 89129 